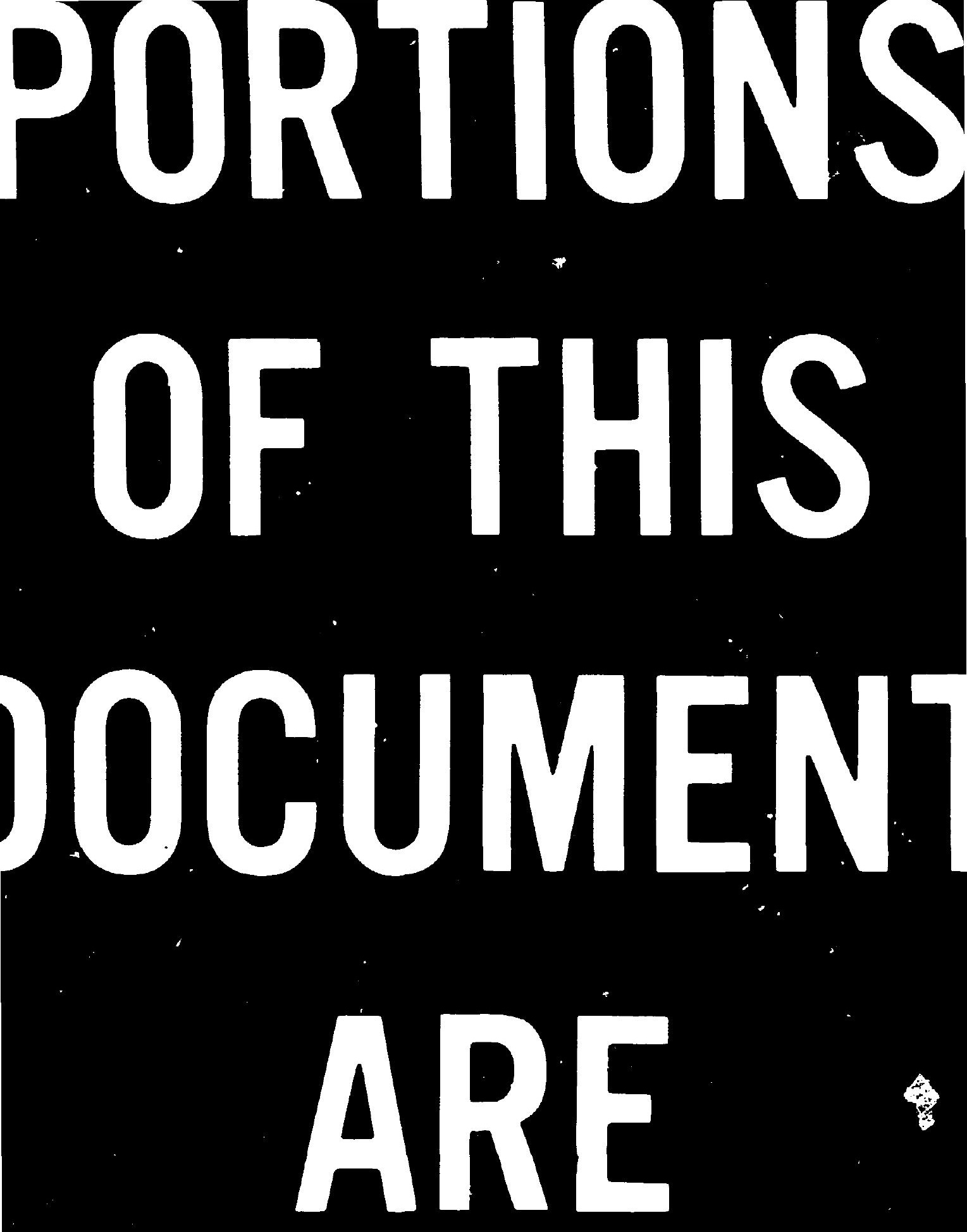




\title{
Safety Analysis Report for Packaging (SARP) of the Oak Ridge National Laboratory Shipping Cask D-38
}

\author{
B. B. Klimá \\ L. B. Shappert \\ R. D. Seagren \\ W. D. Box
}

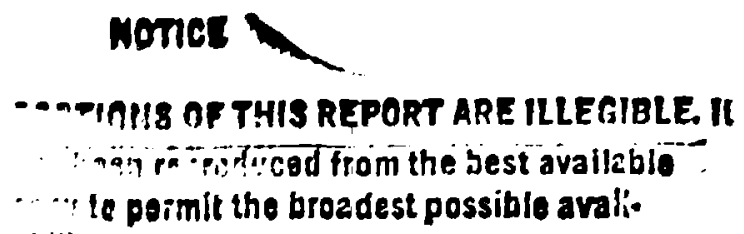


, NOTICE

PORTIONS OF THIS REPORT ARE ILLEGIBLE It

has been reproduced from the best available copy to permit the broadest possible avait

ability.

OR.NL-5406

Dist. Categnry UC-iI

Contract No. W-7405-eng-26

CHEMICAL TECHNOLOGY DIVISION

SAFETY ANALYSIS REPORT FOR PACKAGING (SARP) OF THE

OAK RIDGE NATIONAL LA.BORATORY

SHIPPING CASK D-38

B. B. Klima*

L. B. Shappert

R. D. Seagren

W. D. Box

*Retired. Current address: Roane State Community Collese, Harriman, Tennessce.

Date Published: April 1978

Oak Ridge National Laboratory

Oak Ridge. Tennessee 37830

operated by

UNION CARGIDE CORPORATION

for the

DEPARTMENT OF ENERGY

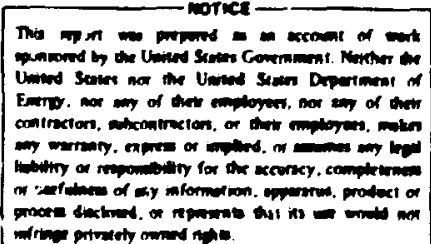

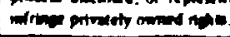


TABLE OF CONTENTS

ABSTRACT

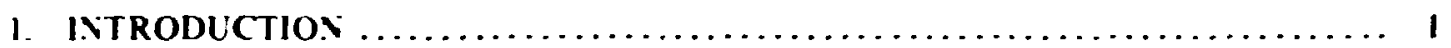

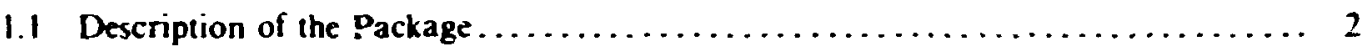

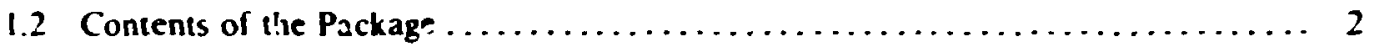

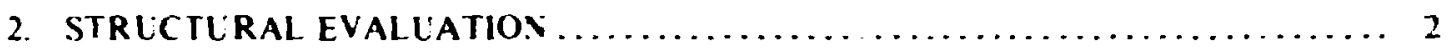

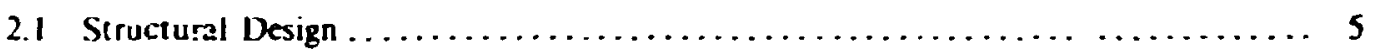

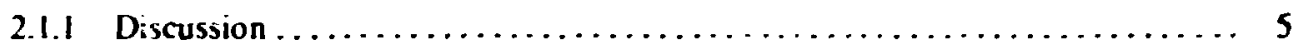

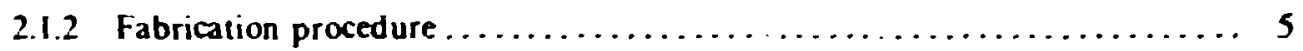

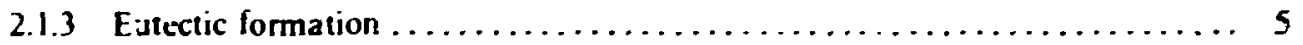

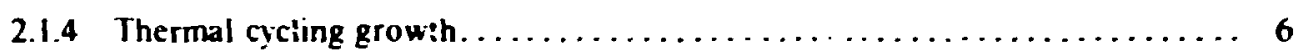

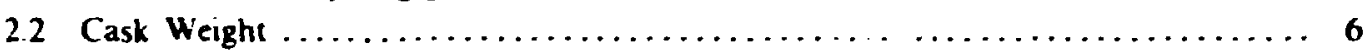

2.3 Mechanical Properties of Materials......................... 6

2.3 .1 Dynamic properties of uranium.................. 8

2.3.2 Shear strength of uranium $\ldots \ldots \ldots \ldots \ldots \ldots \ldots \ldots \ldots \ldots \ldots$

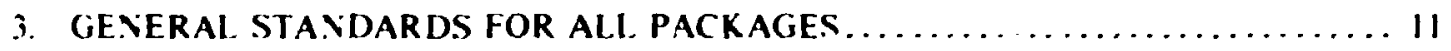

3.1 Chemical and Galvanic Reactions ..........................

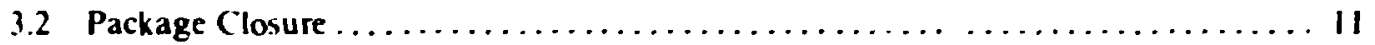

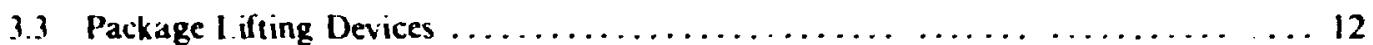

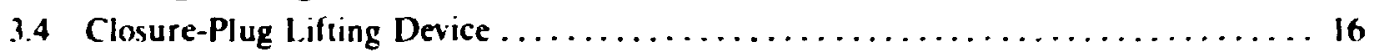

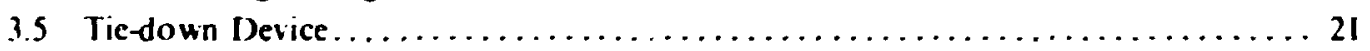

3.5 .1 Tic down of cask to skid............................ 21

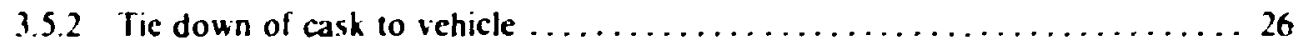

4. STANIDARISS IOR TYPE B AND I.ARGE-QUANTIYY PACKAGING ......... 31

4.1 Load Resistance ................................

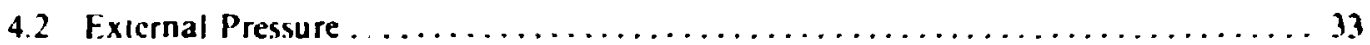

5. COMPI.IANCE WITH STANDARDS FOR NORMAI.

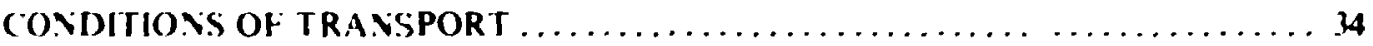

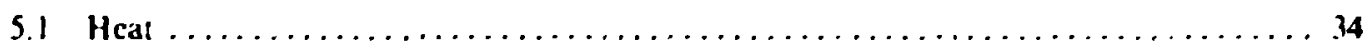

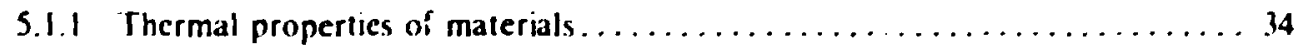

5.1 .2 Thermal model ........................................ 34

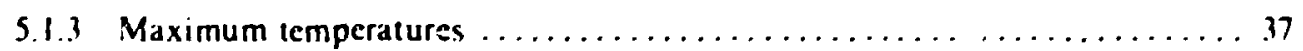

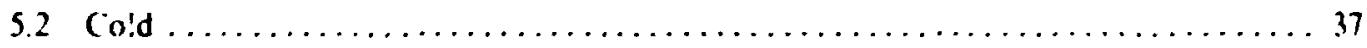

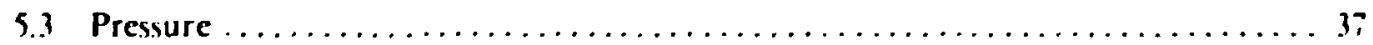

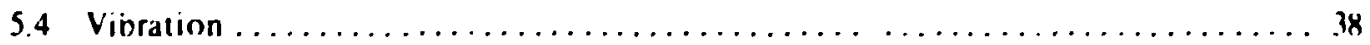

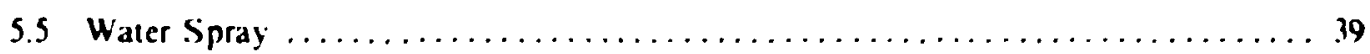




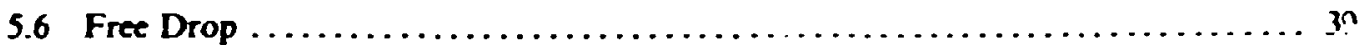

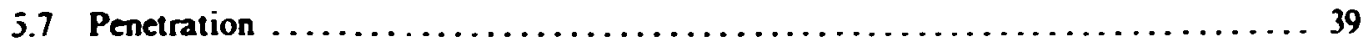

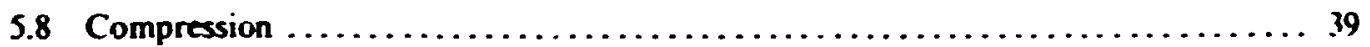

6. COMPLIANCE WITH STANDARDS FOR HYPOTHFTIICAL.

ACCIDENT CONDITIONS .................................. 40

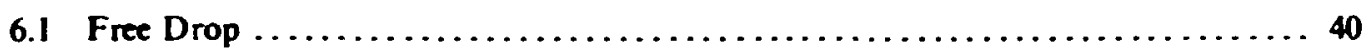

6.1.I Impact on top. jmer............................. 40

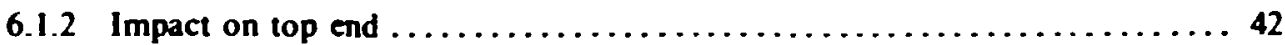

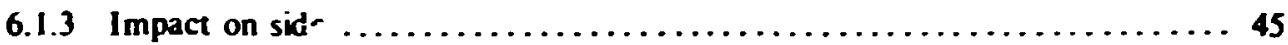

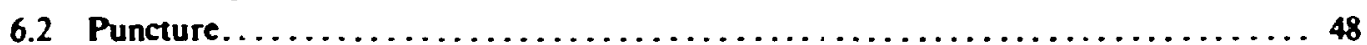

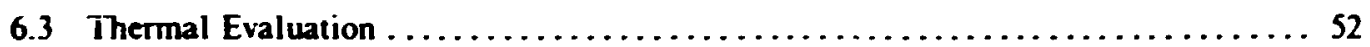

6.3.1 Hypothetical thermal accident condition discussion.............. 52

6.3.2 Thermal properties of materials......................... 52

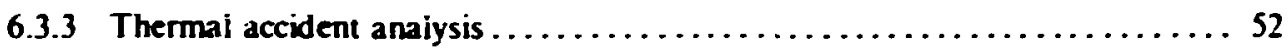

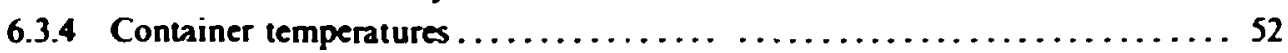

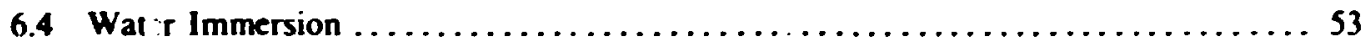

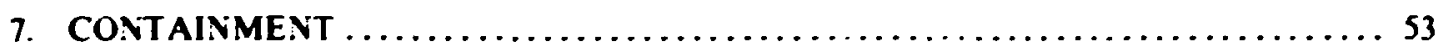

7.1 Containment Requirements for Normal Conditions of Transport ............ 53

7.2 Containment Requirement During the Hypothetical Accident ............. 53

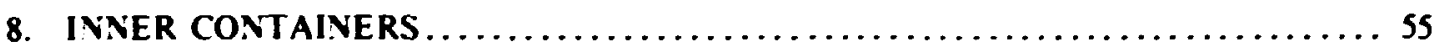

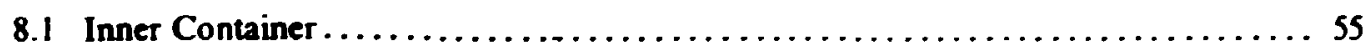

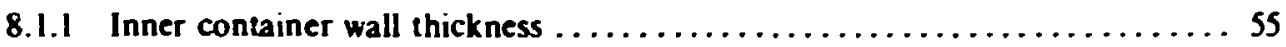

8.1.2 Inner container bottom-fat-head thick ness .................. 57

8.1.3 Inner container top-head thickness .......................... st:

8.2 Special Form and Special Form Containers $\ldots \ldots \ldots \ldots \ldots \ldots \ldots \ldots \ldots$

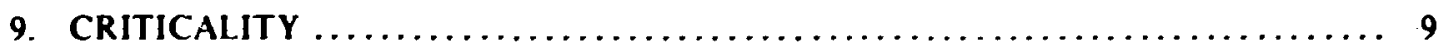

9.1 Evaluation of a Single Package ............................ 59

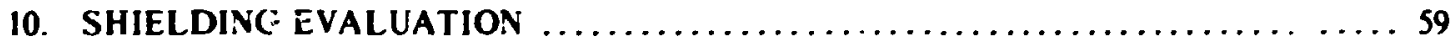

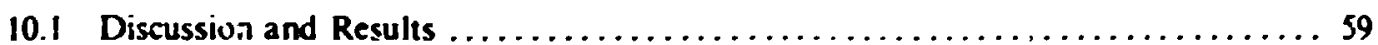

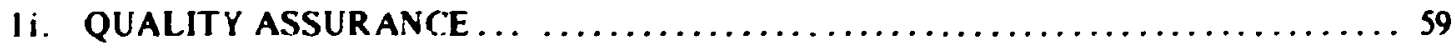

11.1 Fabrication. Inspection, and Acceptance Tests ...................... 59

11.2 Operating Procedures and Routine Inspections $\ldots \ldots \ldots \ldots \ldots \ldots \ldots \ldots \ldots \ldots \ldots$

11.3 Periodic Maintenance and Inspections ........................... 60

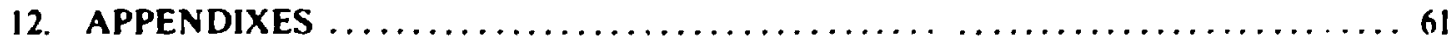

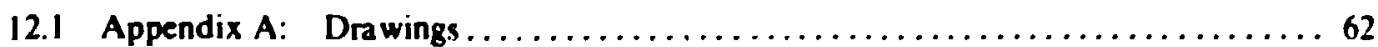

12.2 Appendix B: Asproval Documents....................... 
12.3 Appendic (: Computer Program to Calculate (orner-4)rop

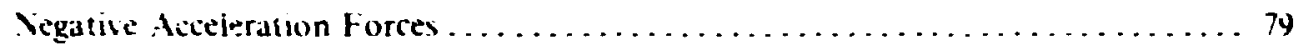

12.4 Appendi.i D: Computer Program te (alculate Sidef)rop Vegative Acceleration Forces ............................ 89

12.5 Appendix E: Inspection of ORNL. Shipping (ask D)-38 :0 Verify Intezrity of Fabrication . . . . . . . . . . . . . . .

!2.6 Apperidiz F: Operating and Inspection Procedures. .................. 95

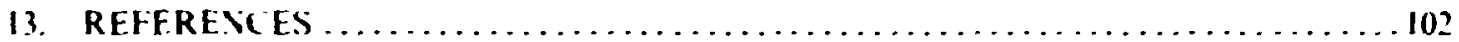




\title{
SAFETY ANALYSIS KEPORT FOR PICKAGING (SARP) OF THE \\ OAK RIDGE NATIONAL LABORATORY \\ SHIPFING CASK D-38
}

\author{
B. B. Klima, L. B. Shappert, R. D. Seagren, and W. D. Box
}

\begin{abstract}
An .nalytical evaluation of the Oak Ridge National Laboratory Shipping Cask D-38 (solids shiprents) was made to demonstrate its compliance with the regulations governmg off-site radioactive material shipping packages. The evaluation encompassed five primary categories: structural integrity, therma! resistance. radiation shielding. nuclear criticality safety, and quality assurance. The results of the evaluation show that the cask compies with the applicable regulation:
\end{abstract}

\section{INTRODUCTION}

The ORNL Shipping Cask D-38 was developed at the Oak Ridge Viational Laboratory. The design was analyzed in 1968' and reevalusted in 1974 to demonstraic compliance with the reguatioris. The results of the analyses are presented in Sects. 2 through 10 oi this report. The package was inspected to ensure that it was built in accordance with the drawings presenied in Appendix A (Sert. 12.1).

The primary use of the container is to provide shielding. impact resistance, and thermal resistance for its contents during both normal transport and hypothetical accident conditions. The package is designed to ship fissile and large quantities of radioactive materials as solids. The package is authorized to be shipped by vessel and motor vehicle. " complies with the Nisclear Regulatory Commission (NRC) regulations contained in the Code of Federal Regulations. Title 10, Part $71,{ }^{2}$ Department of Energy(DOE) Manual Chapter 0529, ${ }^{3}$ and all Immediate action Directives (IAD) in effect as of this report date. The cask also complies with U.S. Department of Transportation regulations published in the Cosis of Federal Regulations. Title 49. Part 173.

The package is also certified by the Department of Transportation as meeting the specific requirements of the Intemational Atomic Energy Agency's (IAEA) "Regulations for the Safe Transport of Radioactive Matirial," Safety Series No. 6, 1967 Edition.

Calculations, engineering logic, and all related documents which demonstrate compliance with specifications are presented in subsequent sections of this report. Copies of the approval Jocuments are reproduced in Appendix B (Sect. 12.2).

The shipping container was fabricated and originally assigned ORNI. No. 4S:-148. Later. the Departmeat of Transportation assigned Special Permit No. 5787 to the container. An interim certificate of compliance has heen issued by the NRC 


\section{I Description of the Package}

The ORNL Shipping Casik D-38 (see Appendix 12.1) is illustrated in Fig. 1.1. The cask consists of a 22-5 8-in.-tall cylinjer that has an outside diameter of 12-3 4 in. and a cavity measuring 6-1, 16 in. in diameter by 13-13: 16 in. deep. It is shielded by $2-3.4$ in. of depleted uranium. The outside shell is 0.41 -in.-thick (nominal) stainless steel, and the cavity wall is 0.28 -in.-thick (nominal) stainless siel. The cask has a depleted uranium-filled closure plug that bolts into the top of the cask. This plug is sealed to the cask body by a neoprene gasket. The top of the cask is protected during shipment by a bolted-down shroud to prevent using the closure-plug lifting $\therefore \mathrm{rs}$ and the top of the cosk lifting trunnions as tie-down points. The shroud is labeled, "D, Not Remove This Cover During Shipping." The shroud nuts are secured by lockwires and s.als.

The cavity has I drain to permit water removal should the cask be loaded or unloaded underwater.

The cask has twi in.-diam lifting trunnions, each of which has a 3/8-in.-thick by 2 -in.-wide outer support strap. The support strap is welded to the body and is given auditionai support by a triangular 12 -in.-thick gusset plate.

Figure 1.2 shows the ORNL Shipping Cask D-38 disassembled on its skid with all of its components marked.

\subsection{Contents of the Package}

The cask is intended to be used to transport fissile and large quantities of radioactive material in the form of solids. including mixed fission products, fuel elements, and vaste products. The solids wili be shipped inside a spec $2 R$ container or a welded inner container (see Sect. 8) placed inside the inner cavity. "Special Form" solids and "Special Form Containers" may be shipped in the inner cavity. The quantities of fissile materials carried are limited to $500 \mathrm{~g}$ of ${ }^{235} \mathrm{U}, 350 \mathrm{~g}$ of ${ }^{233} \mathrm{U}$ or ${ }^{339} \mathrm{Pu}$, or $350 \mathrm{~g}$ of any combination.

The radieactive material shall not exceed a maximum thermal decay energy of $80 \mathrm{~W}$. Quantities ge eater than $20 \mathrm{~W}$ may be carried only if the package is transported in a vehicle reserved ! , :he sole use of the consignor. The dose rates external to the cask will be limiied to those pernitted by the Department of Transportation," (DOT).

\section{STRUCTURAL EVALUATION}

The package complies with the structural requirements of the regulations (see Sects. 2-6). The calculations, test results. and engineering logic presented in the following sections demonstrate compliance with li:se performance criteria. The effects of both normal transport and specified accident conditions on the structural integrity of the package are considered. 


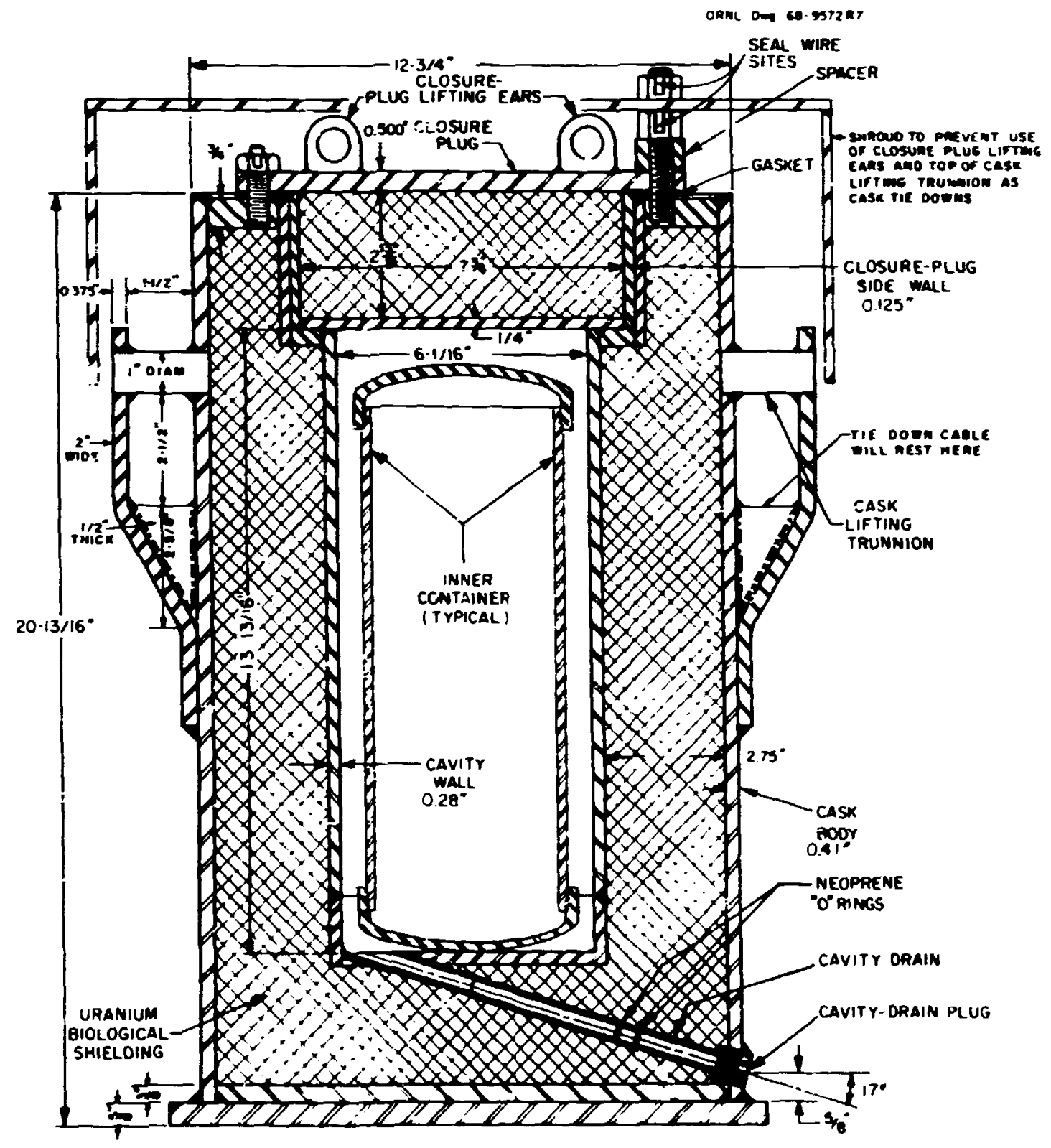

Fig. 1.1 Cross section of the ORNL Shipping Cask D-38. 


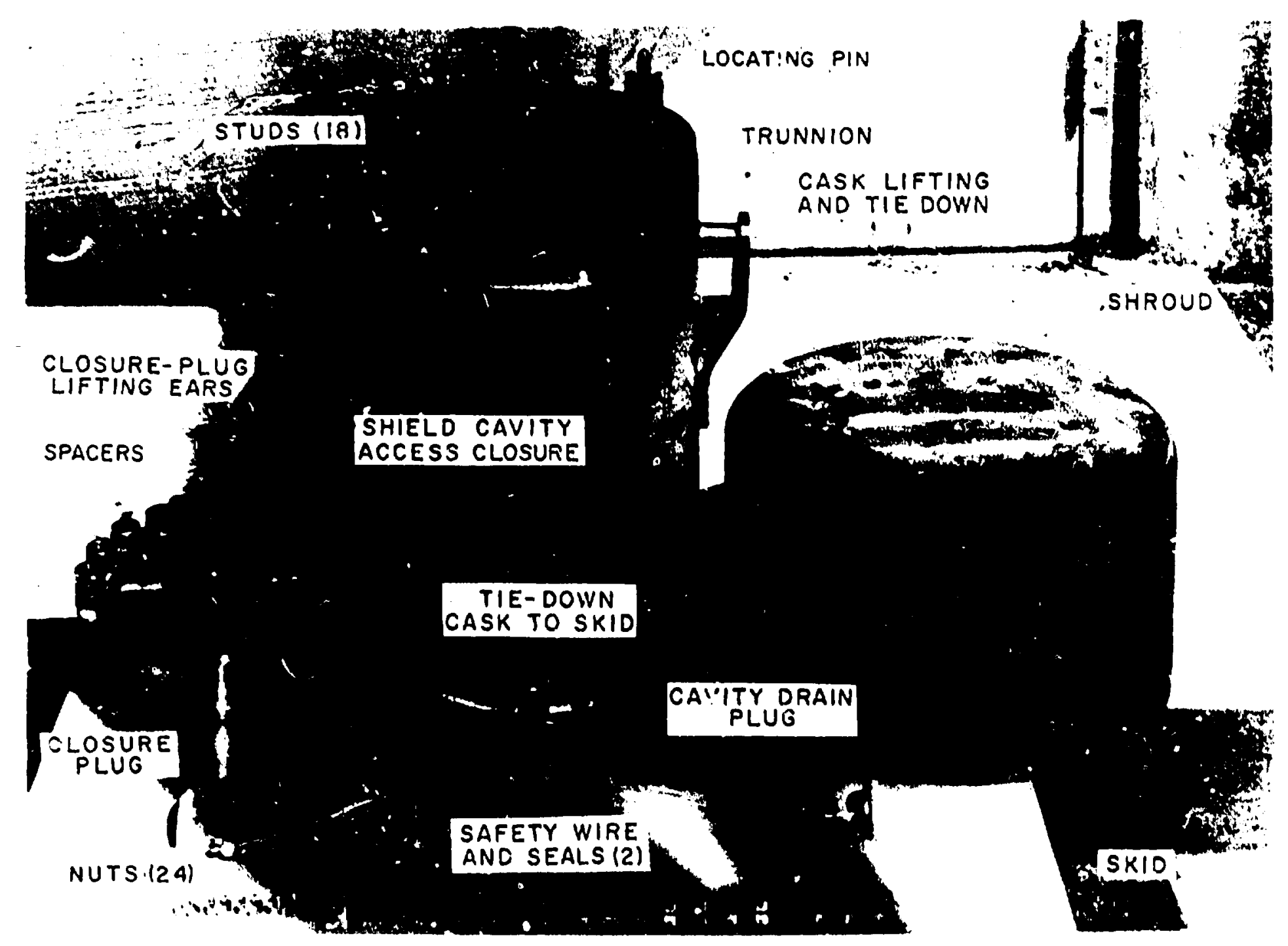

Fig. 1.2 Disassembled vlew of the ORNL Shipping Cask D-38 and idantification of its components. 


\subsection{Structural Design}

\subsection{Discussion}

The as-built drawing tor the D-38 cask is shown. and all other applicable drawings a.e listed in Sect. 12.1. The p:incipal structural members of the cask are: (I) the cylinder of cast uranium. which forms the cask body and its stainless steel cladding: and (2) the closure plug. which consists of one piece of uranium also clad with stainless steel plate.

The uranium used to ia. ricate the shielding for this cask was depleted to $0.2 \%$ "

\subsubsection{Fabrication procedure}

Cask bod: The 300-series stainles; steel outer shell of the cask was fabricated using 12-in. sched 30 pipe to which was welded the 38 -in.thick bottorit plate and the lifting trunnions. After assembly of this weldment. the interior of the outer shell was machined to ensure a 10-mil-diam clearance between it and the outer diameter of the uranium casting.

The 300-series s'ainless steel inner shell and top were welded as a unit: the outer diameter of the shell was then machined to ensure a 10-mil-diam clearance between it and the inside diameter of the uranium casting.

The hule for the drain tube was machined into the uranium casting: the entire casting was inspected for naws. cracks. and other discontinuities and was found to be suitable for the shield of the D-38 cask.

The urnnium casting was assembled inside the outer shell: the inner shell was then inserted into place. The drain tube was inserted into its preparet hole. 2 ad a seal weld was made to join the inner shell and the drain tube. After inspection of the weld. the exterior of the drain tube was seal welded to the outside of the cask. After inspection of the scend weld. the final seal weld was run betwen the top of the outer shell and the top plate of the inrer she!l: this weld was not a full-penetratior weld.

Cask cmir. The closure plug was constructed in the same manner as the hody. The top plate ard outer shell were machined after fabrication to provide a 10-mil-diam cleararice between the uranium casting and the plug assembly. After assembly of the uransum in the plug. the hottom closure plate was seal welded to the plug: this was not a full-penetration weld.

\subsubsection{Euscric formasion}

At an interface of stainiess steel ând uranium. an aifoy with a meltirg point of athout $1450 \mathrm{~F}$ can he formed tinder certain conditions. In the [)-38 cask. this possihility is minimized b:cause of the gap designed wito the cask between the stainless steel veldment and the uranium shicld. Helium was used to fill the gaps hetween the uranium shicld and the stainless secl weldment. The helium at inosphere prevents oxiddtion of the uranimm inctal. 
Tests have shown that after a sampie sandwich of 304 stainless steel and uranium was heated to $1475^{\circ} \mathrm{F}$ foi $1 \mathrm{hr}$, a small amount of eutectic was iormsd. It should be noted that in this test sandwich, the surfaces of the stainless steel and the uranium were hored for intimate contact. In the D-38 cask there is a 10-mil gap between the component parts; since stainless steel has a greater therma, coefficient of expansion, this gap will increase slightly between the outer shell and the uranium shield (see Table 2.1 in Sect. 2.3).

The fire in the "hypothetical accident" (discussed in Sect. 6.3) is of only a 36-min dumation, and it is possible that some eutectic will be formed; however, (1) the removal of metal due to the eutectic formation is expected to be less than 1/4 in., and the cask shielding would stiil be adequate to shield the source without exceeding the requirements of DOE Manual, 0529; and (2) the tests ${ }^{6}$ indicate that insufficient eutectic would be formed under ideal conditions in a 30 -min fire to erjde through the sched 30 outer stainless steel shell.

\subsubsection{Thermal cycling grow:th}

The uranium metal, as cast, probably has radially orientated columnar crystals. Under idverse thermal cycling conditions, this type of crystal orientation could produce some alterativis: in the dimensions of the uranium castings.' It has been noted that if the top temperature of cycling never exceeds 300 to $350^{\circ} \mathrm{C}\left(572\right.$ to $\left.662^{\circ} \mathrm{F}\right)$, growth by thermal cycling is neglible. ${ }^{7}$ The temperatures experienced in normal transport are well below that range. The ter.,peratures associated with the hypothetical accident thermal test are above that range, and a change in the size of the uranium castings can be expected. Shou!d an actual fire befall the cask, the change in uanium sasting size will depend on the rate of temperatuie rise, the duration and top temperature reached, and the rate of cooling. In any case, one cycle in which thermal ratcheting occurs will produce no effect on the integrity of the cask since the thermal expansion stresses will be at a minimum due to the similarity of physical properties of deplete.t uranium and 304L stainless steel.

\subsection{Cask Weight}

The weight of the package, its parts, and the contents are shr.wn in Table 2.2.

\section{$\therefore 3$ Mersiarical Properties of Materials}

The niechanical properties of uranium and stainless steel are summarized in Table 2.1. 
Table 2.1. Mechanical properties of uranium and stainless steel

\begin{tabular}{lccc}
\hline Properties & Stainless steel & Uranium $^{2}$ \\
\hline
\end{tabular}

\section{Static properties}

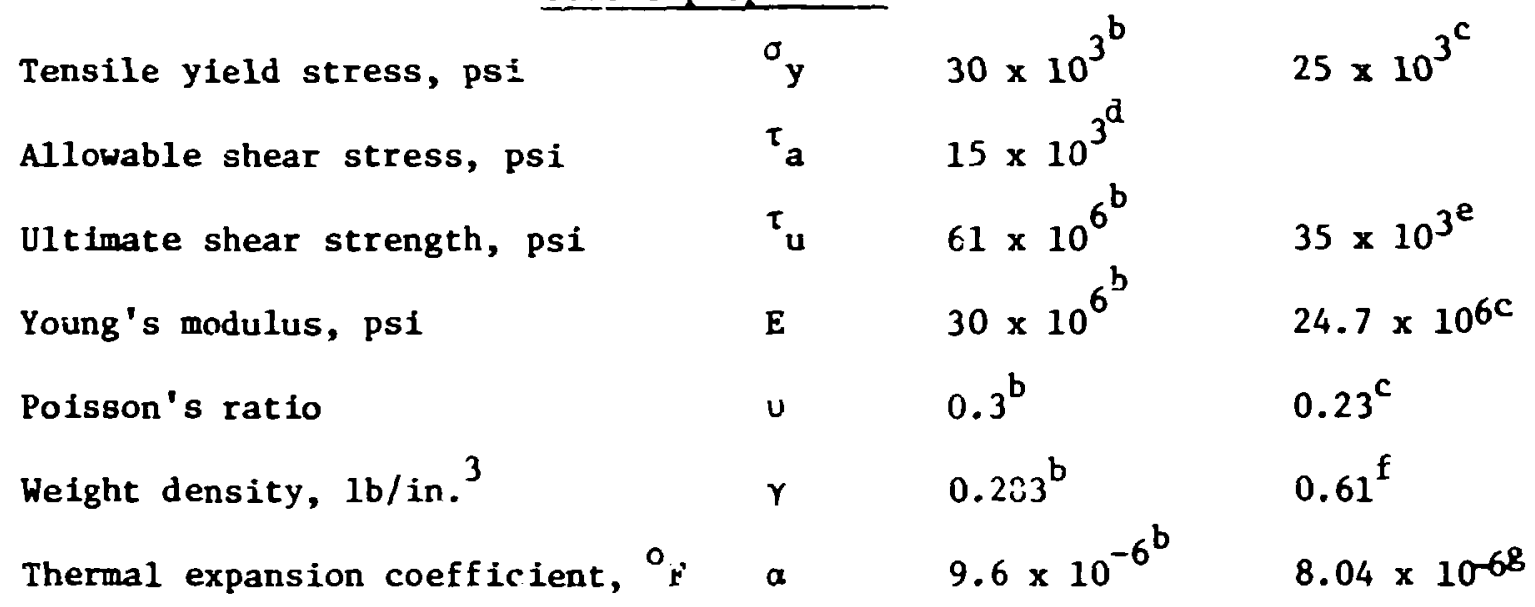

Dynamic properties

\begin{tabular}{rrrr}
$\begin{array}{c}\text { Specific energy, } \\
\text { in.-1b/in. } 3\end{array}$ & $S \min$ & $10 \times 10^{4}$ & $4 \times 10^{\mathrm{e}}$ \\
\hline
\end{tabular}

${ }^{a}$ Beta heat $t r$ sated and oil quenched.

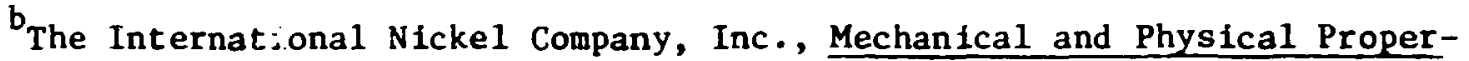
ties of Austenitic Chromium-l'ickel Stainless Steel at Ambient Temperatures, 1953.

${ }^{C}$ A. N. Holden, Physical Metallirgy of Uranium, Addison-Wesley, Reading, Mass., 1958.

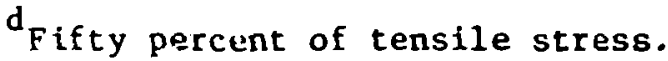

eJ. A. Boutlet, J. H. Evans, and K. K. Chipley, Safety Analysio Report for Packaging: The ORNL Uranium-Shialded Shipping Cask, ORNL/ENC/TM-4 (1977).

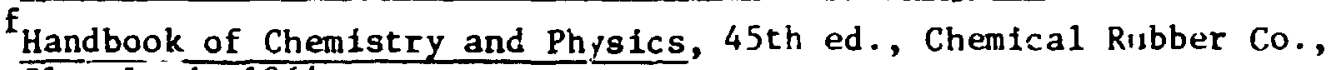
Cleveland, 1964 .

${ }^{8}$ C. R. Herrington and A. E. Ruehle, Uranium Production Technology, Van Nostrand, New York, 1959. 
Table 2.2. Weights of cask and contents

\begin{tabular}{lr}
\hline \multicolumn{1}{c}{ Component } & $\begin{array}{r}\text { Weight } \\
(1 \mathrm{~b})\end{array}$ \\
\hline Shroud & 50 \\
Cask body (without closure plug) & 1100 \\
Closure plug & 150 \\
Total cask weight & 1300 \\
Approximate weight of cont ants & 50 \\
Total weight & 1350 \\
Skid & 175 \\
Total shipping weight & 1525 \\
\hline
\end{tabular}

\subsubsection{Dynamic properties of uranium}

The literature contained little data concerning the dynamic compressive properties of uranium; however, tensile strength data were found in refs. 7-10. The uranium in the D-38 shipping container was cast in a graphite mold, and the grains in the casting are probably aligned. Tensile strength data for this material are plotted in Fig. 2.1. Conservative approximations for these data are shown in Figs. 2.1 (dashed line) and 2.2. Figur: 2.2 also shows compressive curves obtained by muitiplying the tensile stresses by $(1+\epsilon)(1-\epsilon)$. It is assumed that the true stress-strain properties of the material are the same for tension and compression.

\subsubsection{Shear strength of uranium}

Information on the direct measurement of the ultimate shear strength of uranium was unavailable in the literature; however, ref. 11 indicates that, in general, ultimate shear strength is approximately $70 \%$ of ultimate tensile strength. Furthermore, since tensile specimens generaliy fail along a plane inclined $45^{\circ}$ from the specimen axis, the ultimate shear strength $\left(\tau_{u}\right)$ is found as follows: 
ORNL OWG 74-8958

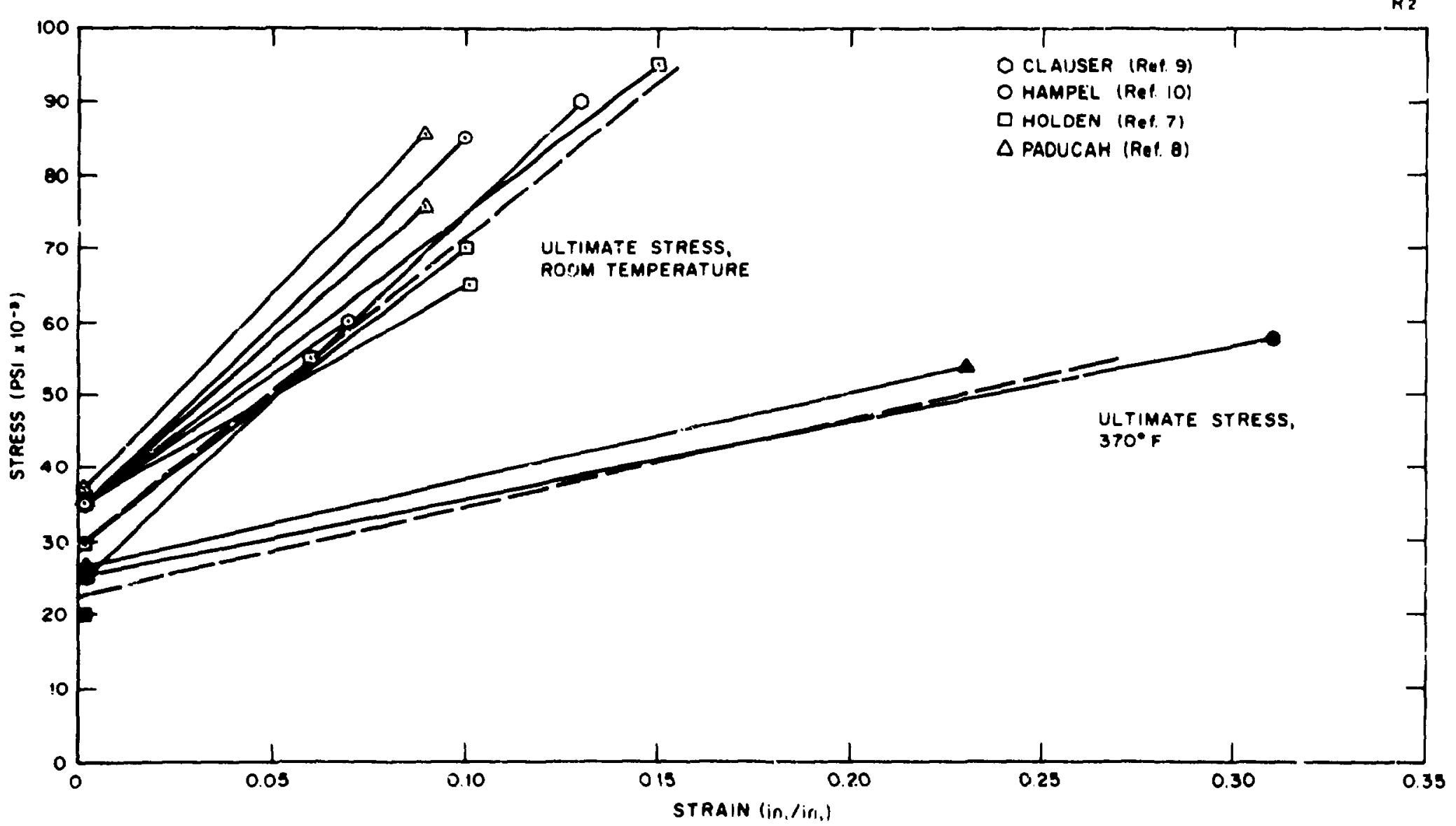

Fig. 2.1 Tenslle strength data for uranium. 


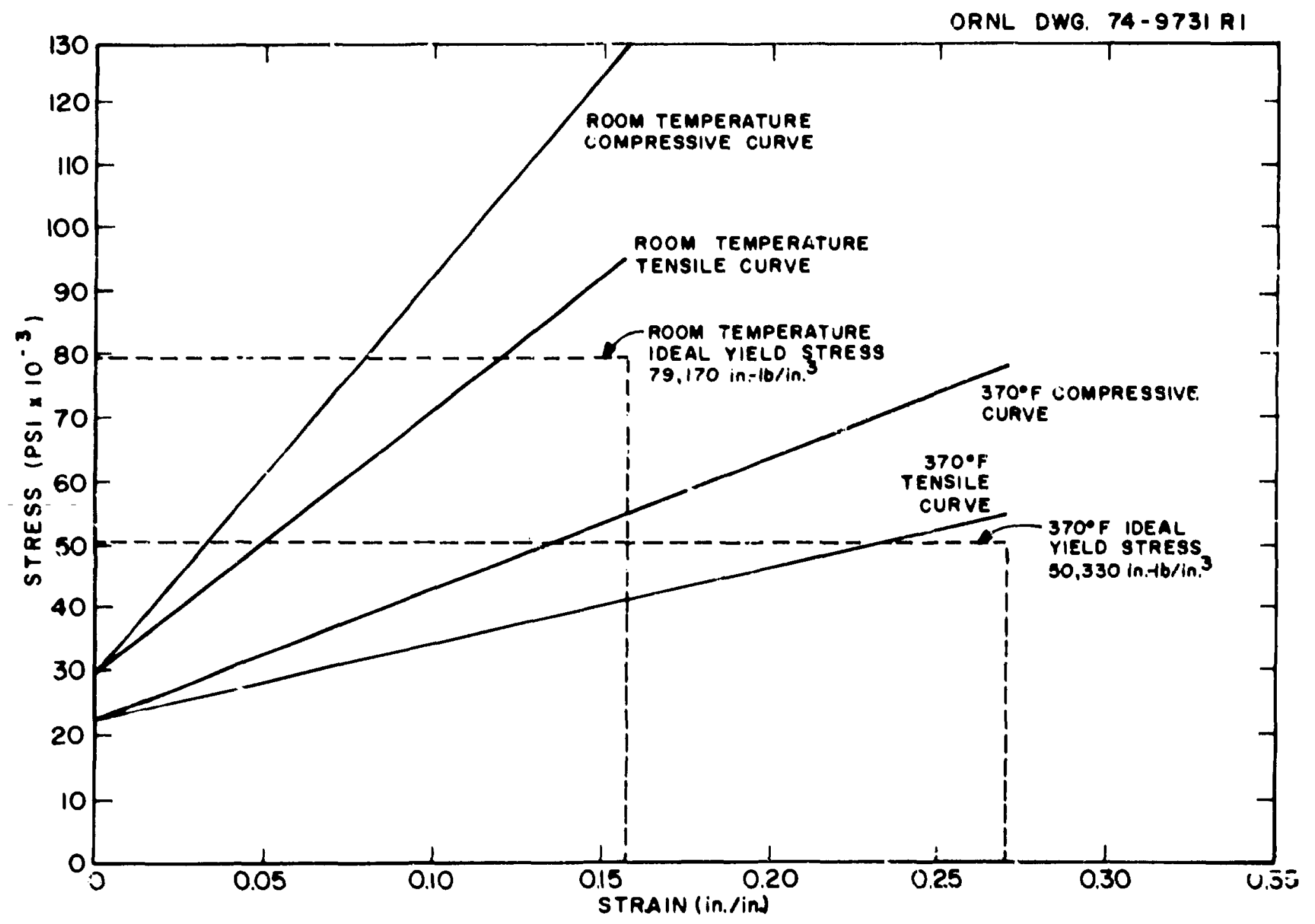

F1g. 2.2 Uranium stress-strain curves. 


$$
I_{x}=\sigma_{*} \cos 45^{\circ}=(50.000 \times 0.7)=35.020 \mathrm{psi} .
$$

where

$\sigma_{z}=$ ultimate tensike strength. 50.000 psi.

\section{GENERAI. STANDARDS FOR ALL PACKAGFS}

The general standards for all packaging cover the chemical and galvanic reaction of the mattrials of the paskage. closure of the package. and the lifting and tie-down devices for the package.

\section{I Chemical and Galvanic Reactions}

The package is fabricated from stainless steel and depleted uranium. The oxidation of uranium in air at elevated temperatures was recognized in the design: therefore. the atmosphe:e that is used to envelop the uranium is helium. The uranium is completely clad witt. stainless steel plate. The cask was built using full penetration welds: the exception was the final closure weld in which penetration was abolt 0.5 in. Recently, the shielding cavity was evacuated to determine that no weld had failed during previous operations with the cask and to backfi!! with heliuin to prevent oxidation of the uranium. Thus. no oxide film should form on the uranium.

When uranium is in contact with stainless steel. it exhibits a tendency to alloy at the interface at a temperature of abont $14 \leq 0^{\circ} \mathrm{F}$ (see Sect. 2.1.3). Linder normal conditions of transport. rask tempcratures should not exceed $300^{\circ} \mathrm{F}$. Therefore, no reaction between the uranium and the stainless steel is possible.

The fissile and radioactive contents of the package are in soiid form and are contained in inner containers (see Sect. 8). "Special Form" materiai may also be shipped in this package as well as material in "Special form containment." These containers and material will be in contact with the stainless steel cladding and will not react with tie cladding.

Experience and inspection have indicated no chemical. galvanic. or other reaction between the claddir:g and the conceainers. or between the containers and their solid contents.

\subsection{Package Ciusure}

The standards speriiy that the package shall be equipped with a positive closure that will prevent inadvertent opei:ing. The paikage closure is held in place by eighteen 12 in. by 13-NC studs. Two of the studs are short and the nuts rest directly on the top fange of the ciosure plug. The other 16 studs have a 3 -in. tall by $1-18$-in.-()D spacer hetween the plug top

flange and the nut to provide an increased energy absorption capacity. Six of the taller sturts are extra long to allow space frr the protective shroud and the additional nuts that wili hold this shroud in place. All of tic studs are drilied and the nuts are slotted so that each nut can 
be equipred with a seal wire. The cask closure is seaied with a 18 -ini.thick neoprene gasket. Thus. with the nuts of the cover and the shroud safety wired. this package is equipped with a positive slosure that iill prevent inadverent opening.

\subsection{Package Lifting Devices}

If there is a system of lifting devices that is a structural part of the package. the regulations require that this syster. shall be apable of supporting three times the weight of the loaded package without generating stress in any material of the package in excess of its yield strength.

A total weight of $1350 \mathrm{lb}$ (see Table 2.1) was used for the cask and contents. The loading or force is calcuhted as folk ws:

$$
P=F \underline{W}=3(! 350)=4050 \mathrm{Ib} .
$$

where

$$
\begin{aligned}
& P=\text { loading. } \mathrm{lb}, \\
& F=\text { factor. } 3 . \\
& W=\text { weight of cask and contents (see Table 2.2), } 1350 \mathrm{lb} .
\end{aligned}
$$

A computational model of one of the cask lifing devices or trunnions is shown in fig. 3.1. The approach used to analyze the casklifting device is similar to that used for a propped beam. The deflection. $\Delta$. of the unrestrained end (the left end in Fig. 3.1) of the beam (1-in.-diam rod) is numerically equal to the elastic elongation of the $38 \times 2 \times 2-12$ in. bar securing the left end. An expression for the elongation of the bar may be uritten as follows:

$$
\Delta=+L_{b}=(-5 \mathrm{E}) L_{b}=-\mathrm{R} L_{b} \mathrm{AE}=-\mathrm{R}(2.50)(0.75) 30 \times 10^{-6}=-1.111\left(10^{\circ}, \mathrm{R}\right. \text { in.. }
$$

where

$$
\begin{aligned}
& \epsilon=\text { strain, in. in.. } \\
& L_{\boldsymbol{\phi}}=\text { length of bar. } 2.5 \mathrm{in} . \\
& \mathbf{S}=\text { stress. psi. } \\
& \mathbf{E}:=\text { modulus of elasticity, } 30 \times 10^{6} \mathrm{lb} \mathrm{in}^{2} . \\
& \mathbf{R}=\text { reaction, th. and } \\
& \mathbf{A}=\text { cro.s-sectional area of bar, } 0.75 \mathrm{in.}^{2} .
\end{aligned}
$$


ORNL Dwg 68.9573R2

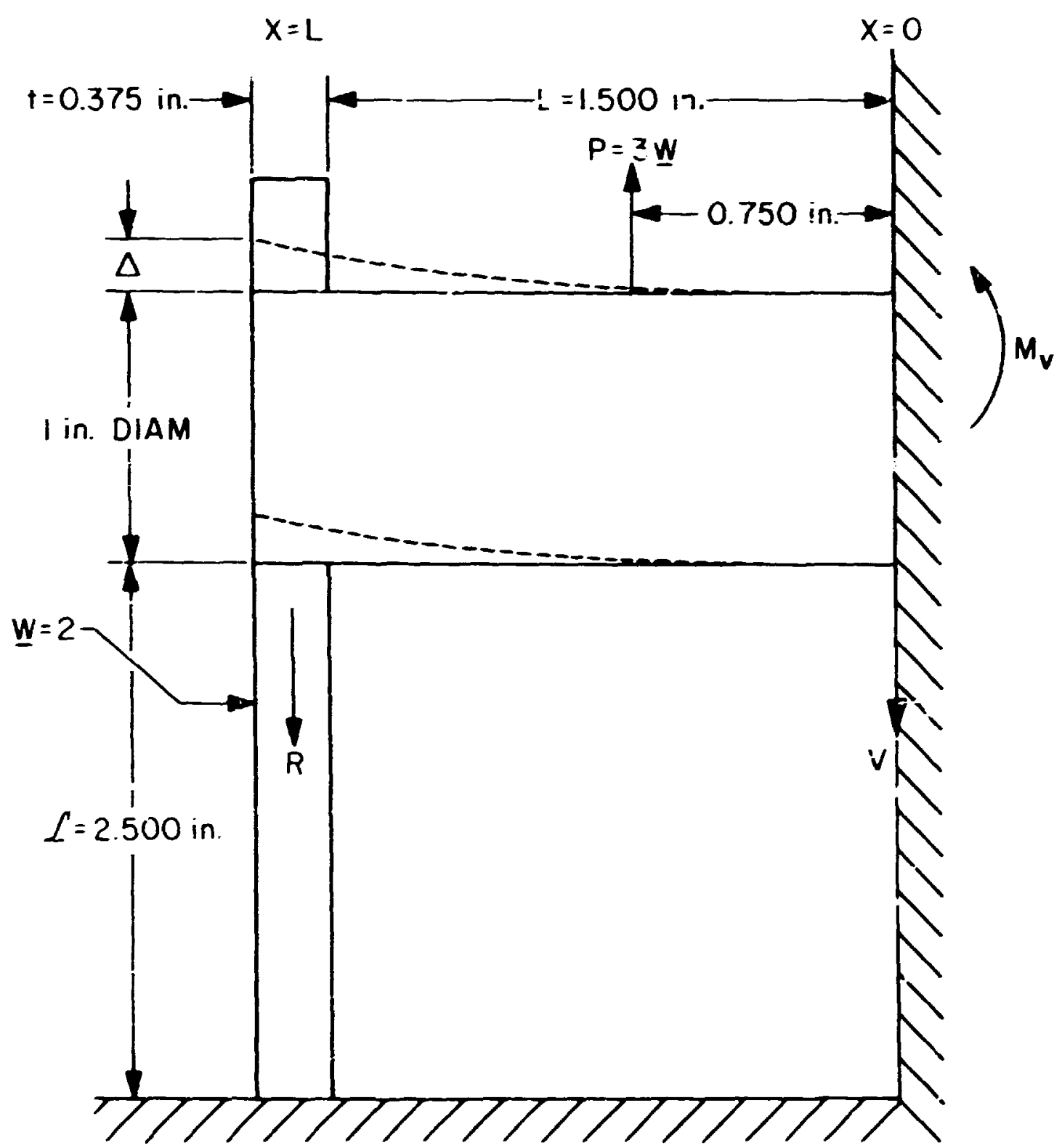

Fi. 3.1. Model of cask liftild trunnion. 
This bean was aralyzed anci equations were derived to permit the cakculation of $R$. is follows.

$$
\Delta=\operatorname{Ri}^{3}, 3 E I-5 P L^{3}, 48 E I
$$

where

$$
\begin{aligned}
& L:=\text { tunnion length. } 1.5 \text { in., } \\
& I=\text { moment of inertia, in. }
\end{aligned}
$$

Equating Eqs. (3) ard :4, we fins?

$$
R L^{3}, 3 E I-5 P L^{3}, 48 E I=1.111\left(10^{-}\right) \mathbf{R}
$$

Substituting, $R(1.5)^{*} 3\left(30 \times 10^{6}\right) \pi 64-5(4050)(1.5)^{3} 494\left(30 \times 10^{9}\right) \pi 64+1.111\left(10^{-7}\right) R=0$

$$
\begin{aligned}
& 7.64 R-9673+1.11 R=0 \\
& R=96738.75=1.06 \mathrm{lb} .
\end{aligned}
$$

The moment of inertia

$$
I=\pi d^{4} 64=\pi(1)^{4} 64=\pi 64 .
$$

where

$$
d=\text { diameter of trunnion. } 1 \text { in. }
$$

Therefore, the reaction, $V$, at $X=0$ is

$$
\mathbf{V}=\mathbf{P}-\mathbf{R}=2944 \mathrm{lh} .
$$

and the moment due to $\mathrm{V}$ at $\mathrm{X}=0$ is

$$
\begin{aligned}
M_{V} & =R L_{1}-P L_{1} 2 \\
& =1106(1.5)-40502(1.5) \\
& =1660-3038=-1378 \mathrm{in} .-\mathrm{lb} .
\end{aligned}
$$

The moment at tile midpoint of the trunnion is

$$
M=k L_{1} 2=1106(1.52)=830 \text { in. }-1 b .
$$

Load, shear, and moment diagrams for the cask lifting trunnion are shown in Fig. 3.2. 
SRNL DWg EB-9574 RS
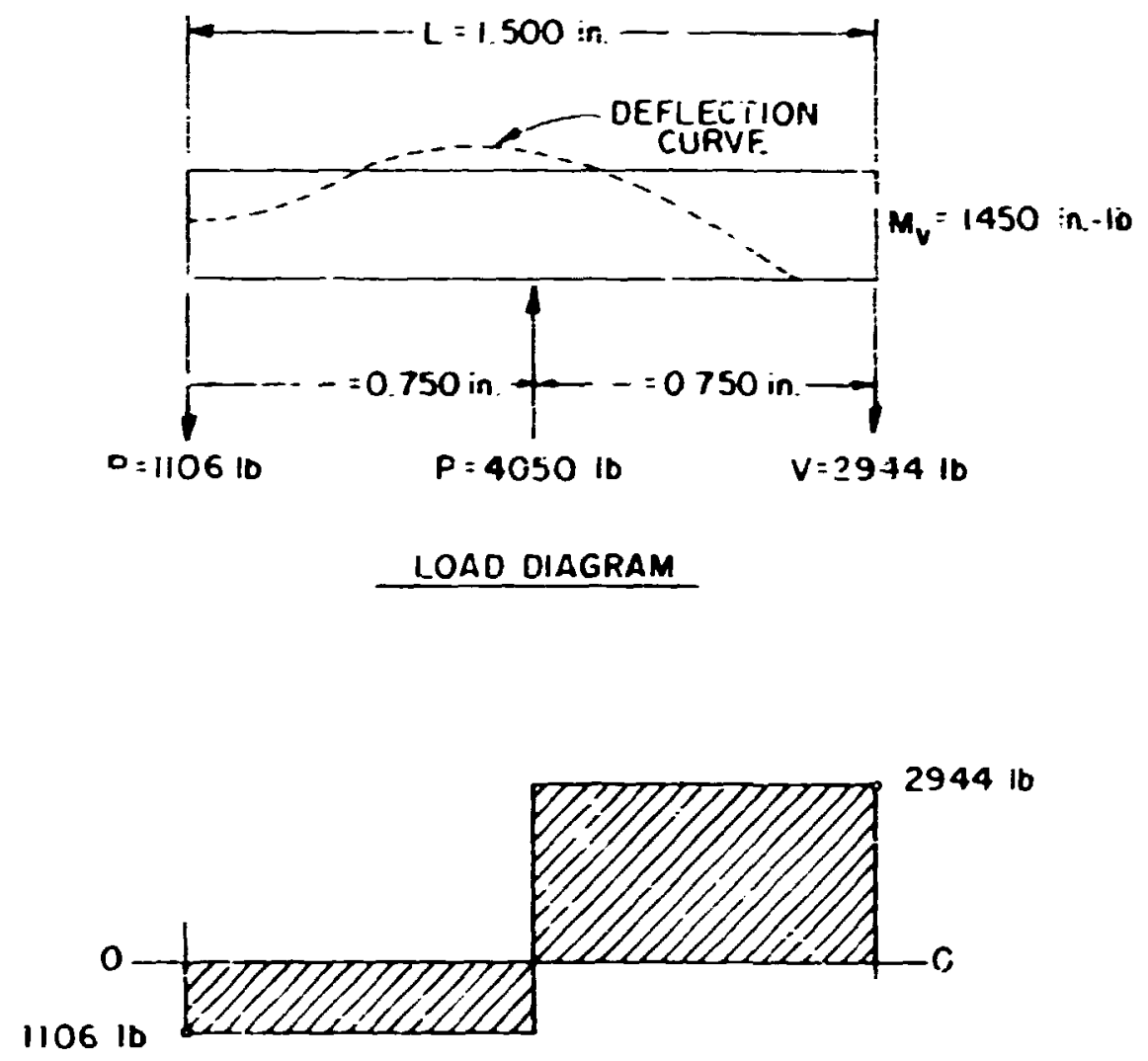

SHEAR DIAGRAM

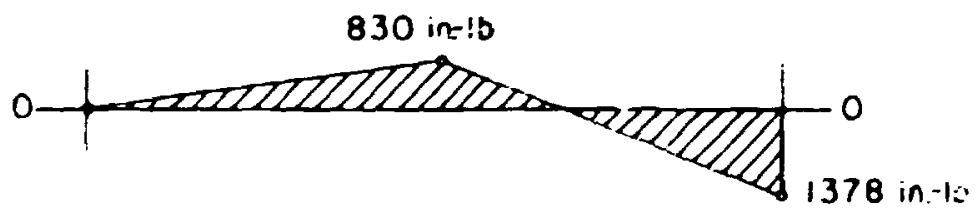

\section{MOMENT CIAGRAM}

Fig. 3.2 Load, shear. and moment diagrams for cask 1 ifting trunnion. 
The maximum bending stress. $S_{k}$ in the cask lifting irunnion occurs at the midpoint. $X=L_{r}, 2$, where the bending is maximum.

$$
\mathrm{S}_{\mathbf{2}}=\mathrm{Mr} I=830(\mathrm{C} .5)+64=8459 \mathrm{psi} \text {. }
$$

where

$$
r=\text { radius of the beam. } 0.5 \mathrm{in} \text {. }
$$

The maximum horizontal sheating stress (maximum shearing stress. $S_{s}$ ) occurs in the length from $X=0$ to $X=L, 2$ at the neutral axis of the section where the bending stress is 0 . That is.

$$
S_{s}=1.38 \mathrm{~V} \pi r^{3}=1.38(2944) \pi(0.5)^{2}=5175 \mathrm{psi}
$$

where

$r=$ radius of the trunnion. 0.5 in.

Since the maximum shearing stress, $S_{\text {s. }}$ is below the allowzisk shear stress for stainless steel ( see ?able 2.1). it is concluded that the cask lifting device exceeds the requirements.

The ratio of the trunnion :o outer-shell welds was considered. Since the irunnion (see Fig1.1) is recessed in the o:ter shell. the welds are considered to be adequnte for the "erris al loads imposed. Should the package lifting device fail due to excessive load. contair.n. it would not be lost and the ability of the package to meet the cther requirements would not be impai-ed.

\subsection{Closure-Plug Lifting Device}

If there is a sy stem of lifting devices that is a structural part of the :id (closure plug) only. the regulations require that this system shall be capajle of supporting three times the weight of the lid (closure plug) and any attachment without generating stress in any material of the lid in excess of its yield strength. It is further required that. unless rendered useless for lifting during transport of the package. the lid lifting or any other systern of lifting devices shall conform to the requirements for the package lifting system.

The cask analyzed in this study has two closure-plug lifting cars. as shown in Fig. 3.?

'I is assumed that the closure plug is lifted with a $45^{\circ}$ two-leg sling. The resulting load on the ears is illustrated in Fig. 3.3.

The load on the lifting car may be calculated by:

$$
F=34 L_{L} \cdot 2 \sin 45^{\circ}=3(150) \cdot 2(0.707)=320 \mathrm{ib} \text {. }
$$




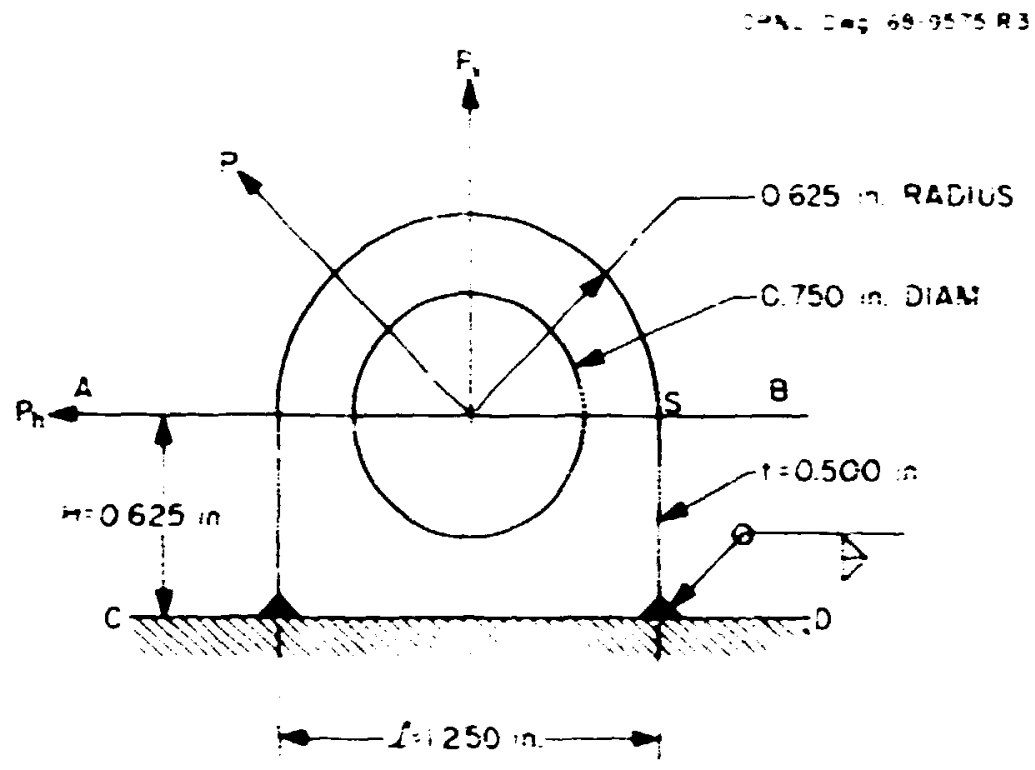

(a) ClosURE PLUG LITTING EAR

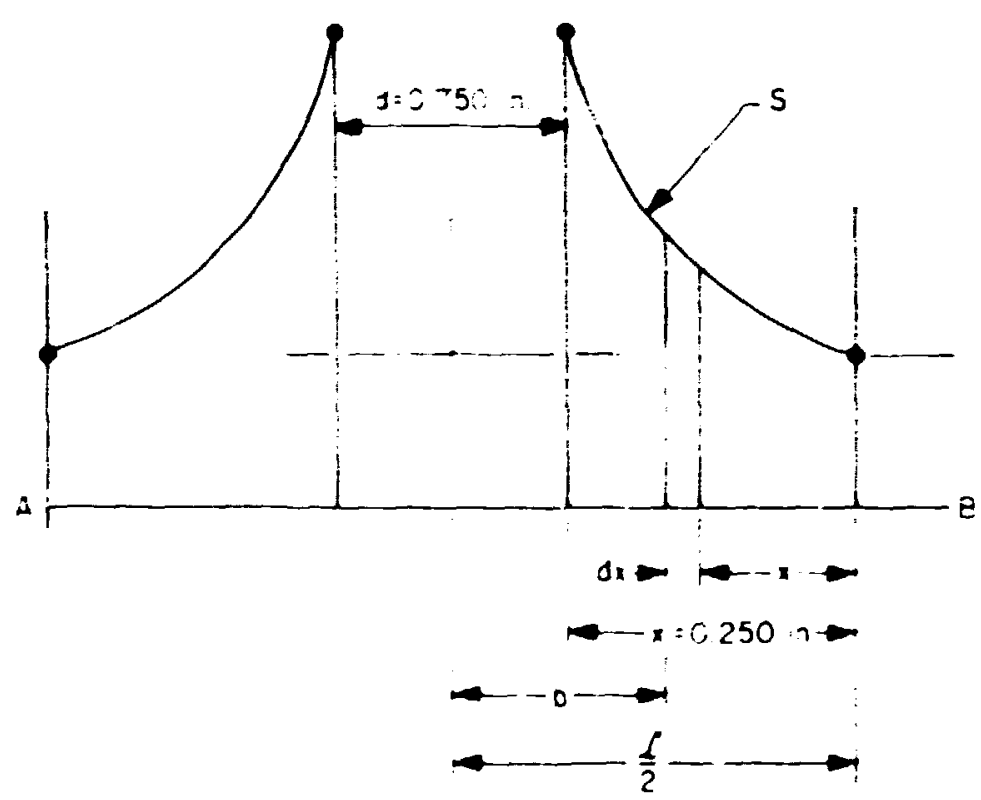

(b) STRESS CISTRIBUTION

AT PiAIE A.3

Fig. 3.3 Analytical model of the closure-plug lifting ear. 
where

$$
\begin{aligned}
P & =\text { load on ar at } 45^{\circ}, \mathrm{lb} . \\
\mathrm{Hi}_{\mathrm{s}} & =\text { weight of lid (see Table } 2.2) .150 \mathrm{lb}
\end{aligned}
$$

The load may be broken into vertical (v) and horizontal (h) components as folkws:

$$
\begin{aligned}
& P_{2}=P \sin 45^{\circ}=225 \mathrm{lh} . \\
& P_{k}=P \cos 45^{\circ}=205 \mathrm{lb} .
\end{aligned}
$$

The vertical component. $P_{x}$. will result in bending stress in the portion of the ar above plane AB. and this must be analyzed by using curved-beam theory. Plan AB is loaded in tension. and the exact distribution is uaknown. Observation of data on phtes with a large width-tu-hokediameier raiso kads to the conclusion that a good approximation of the distribution may be made by assuming a parabolic distribrtion of the form

$$
S=\left(x^{2} \text { a) }-S\right. \text {. }
$$

where

$$
\begin{aligned}
& S=\text { stress on inside fibers. psi. } \\
& X=\text { amount of metal above plane AB. } 0.25 \text { in.. } \\
& \mathbf{a}=\text { constant. (to be determined), } \\
& S_{0}=\text { stress on outside fibers. psi. }
\end{aligned}
$$

The stress in the outside fibers. $S_{\infty}$ is determined as follows:

$$
\text { S. }: P_{v} t i=225(0.50)(1.25)=360 \mathrm{psi} \text {, }
$$

where

$$
\begin{aligned}
& I=\text { inick ness of lifting } \approx a i, \\
& I=\text { width of lifting ear. }
\end{aligned}
$$

The constant. a. is detcrmined as follows:

$$
\text { P. } 2=\int \text { :S dx. }
$$


Substituting Eu- 1151 into Eq. 1 17. and esiablishing the himits of $x$.

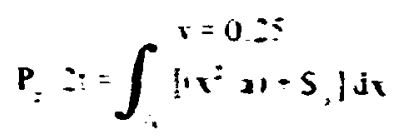

Incegrating and solv ing fo: 2. we feid:

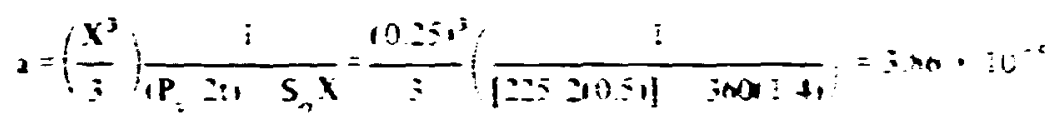

At $x=0.25$. on piane AB. subsistuting in E4. (16), we fint 5i itolai stress:

$$
S_{t}=10.251+3 \times 6 \times 10^{\circ} 1-360=1900 \text { psi. }
$$

120

and the average stress on plane $\mathbf{A B}$ is:

$$
S_{\text {ae }}=P_{:} u l-d u=2250.511 .25-0 .-51-900 p s_{i}
$$

where

$$
d=\text { dameter of hok :- car. } 0^{-5} \text { in at point } 5 .
$$

The shearing stress on plane $A B$ is:

$$
S_{s}=P_{4} A=225 \ln .5 \times 0.251=1 \times 00 p s i
$$

where

$$
A=\text { arca of metal car }
$$

and

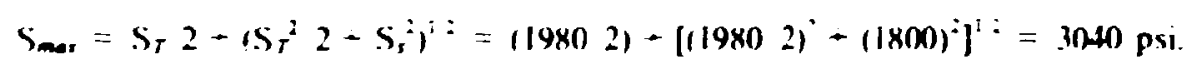

The stress concentrat:on factor $(K)$ for the assumed paraholic stress distribution is

$$
K=S_{T} S_{\text {avg }}=1980900=2.2 \%
$$

The notaion used in ect. 12 was used to check the assumption of a parabolic loading disi-ibution o. plane $\mathbf{A B}$.

H $l=0.625 \quad 1.25=0.5$. 
where

$$
\begin{aligned}
H & =\text { Jistance frem center of hole to end of plate, } 0.52 \leq \mathrm{i} \\
L & =\text { width of plate, } 1.25 \text { in. } \\
2 \mathrm{r} L & =0.751 .25=0.6
\end{aligned}
$$

From these dita and Fig. 2-7 in Design of Machine Elements. ${ }^{13} \mathrm{~K}$ is calculated to be 2.3. It can thus he seen that the assumption ci the curve equation was reasonably accurate. The bending moinent caused by this distribution at the center line [the position of maximum mement; see Hig. 3.3(b)] is found by

$$
M_{m a x}=1 \int_{0}^{0.25} \mathrm{bSdX}=1 \int_{0}^{0.25}[1.2 \mathrm{X} \mid \mathrm{SdX} .
$$

Substituting in Eq. (15) and integrating hetween limits, it is found that

$$
M_{\max }=17 \text { in.-lb. }
$$

The momen: of inertia is ditermined as follows:

$$
t=112 \mathrm{t}(r-L \cdot 2)^{3}=112(0.5)(0.625-0.752)^{3}=6.5 \times 10^{-4} \text { in }^{4}
$$

Using the data in ref. 14 ,

$$
r c=0.5,0.125=4
$$

where

$$
\begin{aligned}
& r=\text { distance irom centroid to } \cdots \text { aral axis, } \\
& c=\text { disiance 'rom n:utral to outer tiber, } \\
& K=\text { stress concentration factor, } 1.20
\end{aligned}
$$

The maximum bending stres

$$
S=-K \text { Mc } /=[-1.2(17)(0.125)]\left(6.5 \times 10^{-4}\right)=-3920 \mathrm{psi}
$$


All stresses are below the limits shown in Table 2.1. It is thus concluded that the closure-plug lifting ear exceeds the iegulation requirements. since all the stresses are less than the yield stress of 300 -series stainless steei.

The 316 -in. fillet weld $\left(1800 \mathrm{fb}\right.$ allowable load per linear inch) ${ }^{\text {is }}$ that secures the ear to closure plug is 3.5 in. long for each of the two ears. Each of the ears is therefore capable of a shear load of $6300 \mathrm{lb}$. It is. therefore. apparent that the welds are sufficiently strong and that they meet other requirements oi the regulation.

Should the lifting ear or the weld fail due to excessive load. containment would not be losi and the ability of the package to meet other requirements would not be impaired.

\subsection{Tiedown Der ice}

The reguiations require that if there is a system of tie-down devices which is a structural part of the package, this system shall be capable of withstanding a static force applied to the center of gravity of the package with a vertical component of two times the weight of the package and its contenis, a horizontal component along the direction of travel of ten times the weight of the packap: and its contents, acso a horizontal component in the transverse direction of fire times the weight of the package and its contents. This applied load shall not generate stresses in any material of the package in excess oi the yield stren?th of that material. In addition. any tie-down device that is a structural part of the package must be sesigned so that failure of the device under excessive load will not impair the ability of the package to meet other $\mathrm{r}$ quirements of the regulations.

The ORNL. Shipping Cask D-38 is normally shipped bolted to its skid as shown in Fig. 1.2. The overall plan for tying the cask to the vehicle is shown in Fig. 3.4. Four wire ropes tie the skid to the vehicle (wire ropes 1. 2.3, and 4). In addition. two wire ropes run through the opening below the trunnions and tie the cask directly to the vehicle iwire ropes 5 and 6). The manner in which the wire ropes pass through the opening below the trunnions and the way the shroud denies use of the top of the trunnion as a tie down are shown in Fig. 3.5 .

Tn demonstrate the adequacy of the tie-downs. calculation, show that bolting the tic-down to the skid is adequate and that the stresse: in the cask body resulting from the wire rope tie-¿own are acceptable.

\subsubsection{Tie down : of cask to skid}

The system used fir tying the cask to the "id that was analyzed in this study corsists of four $i$ in. by 8 -.NC bolts that are used to secure the cask, as shown in Fig. 3.6.

To analyze the tic-down system. the cask is considered to be a cantilevered beam. At the plane of attashment, this hypothetical beam consists of the boits loaded in tension and a strip $a_{x}$ or $a_{y}$. loaded in compression. The $X, Y$, and $Z$ cirection solutions are superimposed to determin? the maximum stress, which occurs in the left rear bolt. The neutral axes of the 


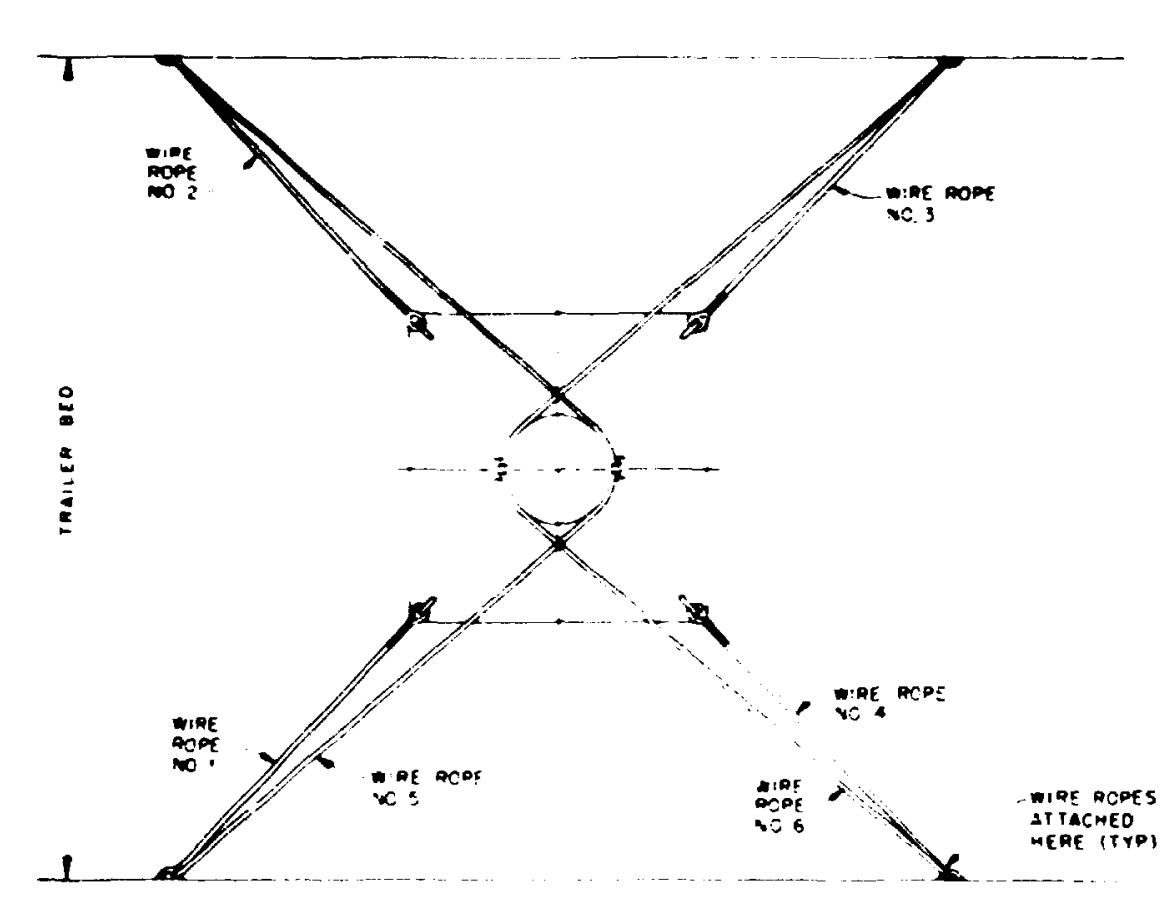

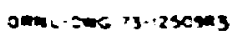

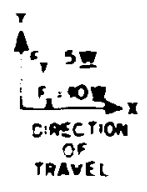

PLAN
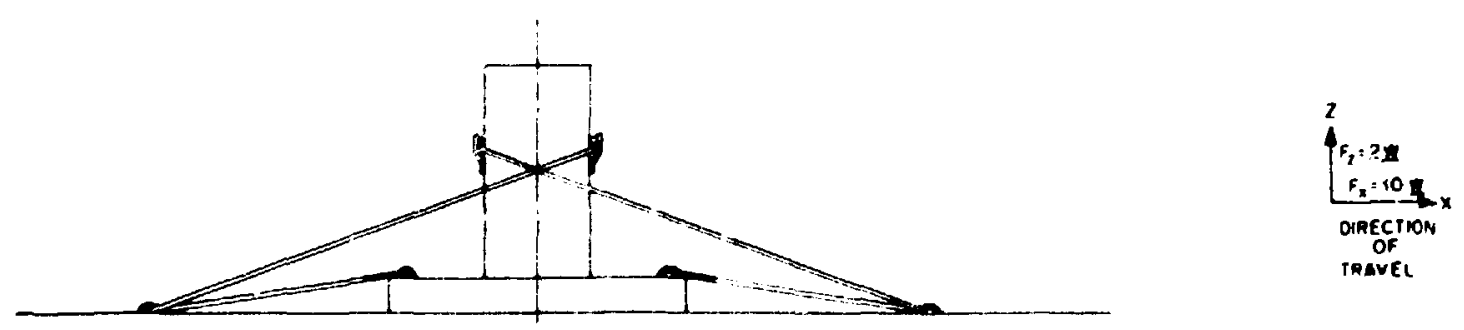

Fig. 3.4 Plan for tie down of the ORNL Shipping Cask D-38 to the vehicle. 
CRNL Dwg 73-12783 R7

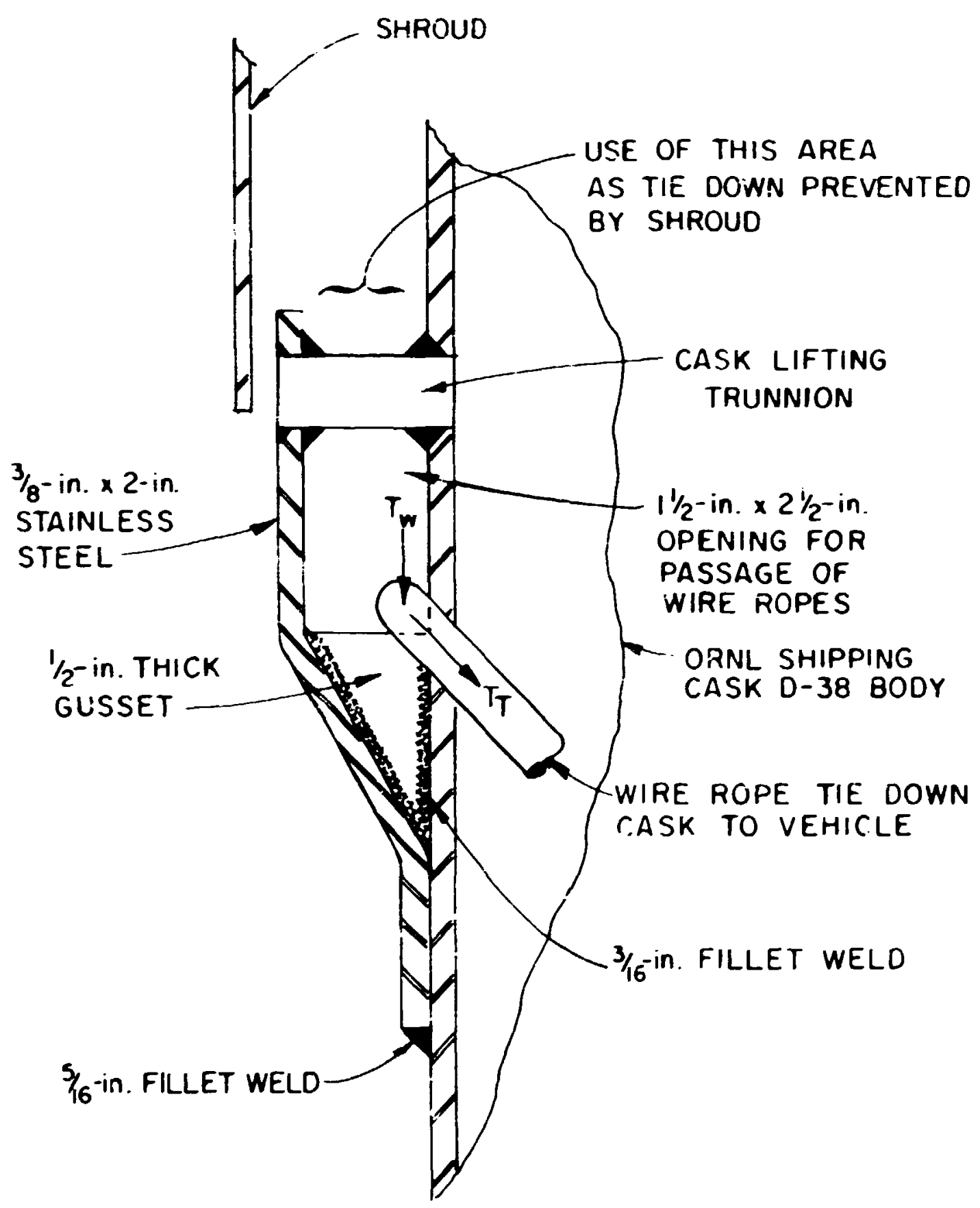

Fig. 3.5 Cask tie down beiow trunnions. 
JAN 2 - $68-9576 R 3$
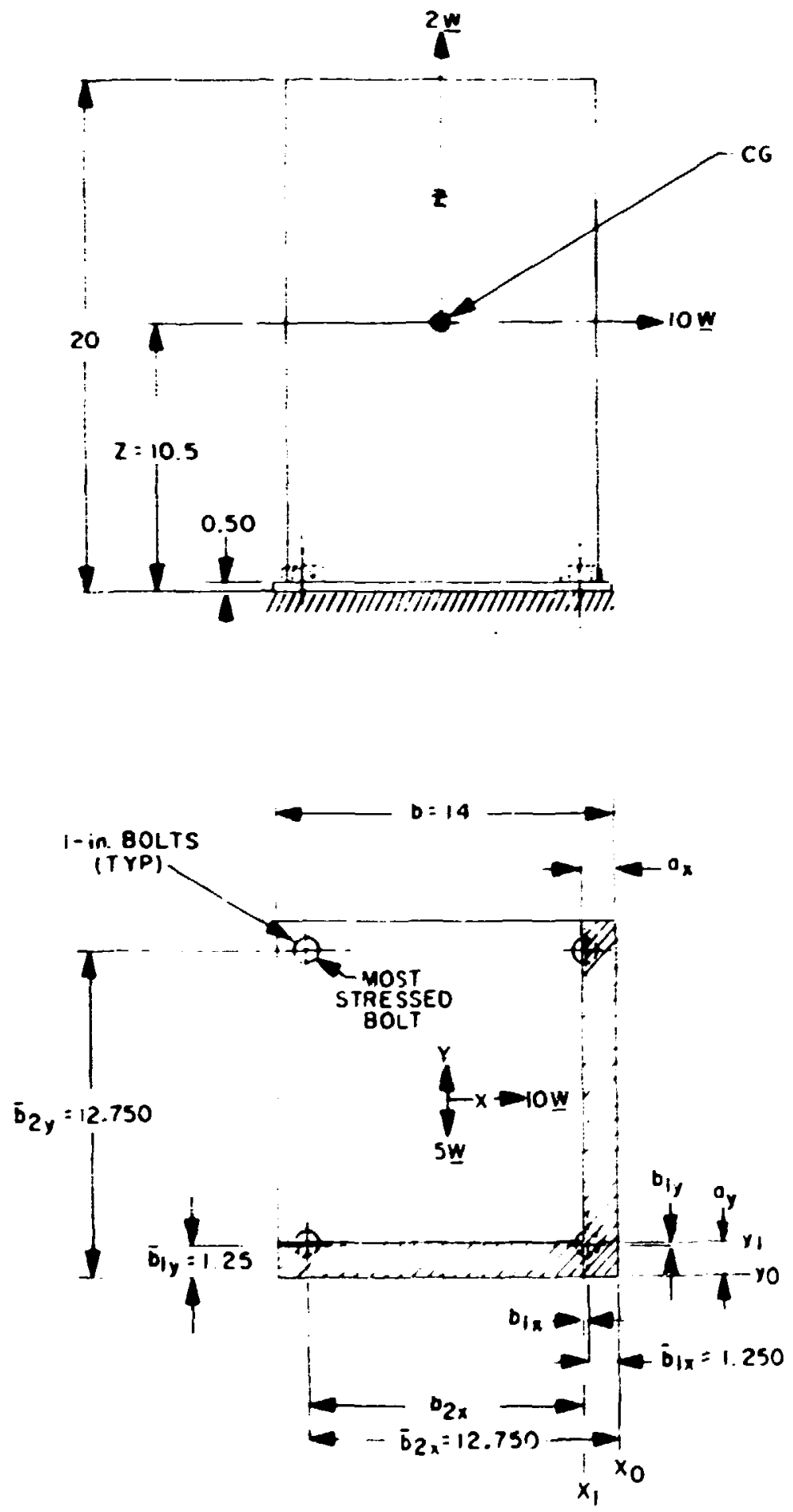

(DIMENSIONS IN INCHES)

Fig. 3.6 Boiting pattern and computaitional model for analys ts of cask the down to skid. 
sections occur at the certroids of the stressed areas. For a first trial. it was assumed that only the rear bolts in each direction are loaded: that is. the forward bolts are in the compression area and. therefore. are not loaded. The reduction in the compression area resulting from the presence of the bolt holes was not considered. The moments atout the $X_{0}$ axis are determined:

$$
\left[\left(a_{x}\right)^{B} b 2\right]+2 A_{a_{x}}-2 A_{\infty} D_{x} x=0
$$

where $A_{\mu}=$ tensile area of a 1 -in. by $8-\mathrm{NC}$ bolt. 0.606 in.: ${ }^{15}$ thus

$$
\begin{gathered}
142\left(a_{x}\right)^{2}+2(0.606) a_{x}-2(0.506)(12.75)=0 \\
7 a_{x}^{2}+1.212 a_{x}-15.453=0 . \\
\left(a_{x}\right)^{2}+0.173 a_{x}-2.208=0 .
\end{gathered}
$$

Using the quadratic formila and rejecting the negative solution.

$$
a_{x}=0.173+\left[(0.173)^{2}-(4)(1)(-2.208)\right]^{12}=1.40 \text {. }
$$

Since $a_{x}=1.40>b_{1:}=1.25$. the assumption that the forward bol:s were not loaded was correct. By symmetry.

$$
a_{x}=a_{y}=1.40
$$

Computing the moments of inertia $I_{x}=I_{y}$.

$$
\begin{aligned}
l_{x} & =13\left(\mathrm{a}_{x}\right)^{3} \mathrm{~b}+2 \mathrm{Ada}_{\mathrm{d}}\left(\mathrm{b}_{2 x}\right)^{2} \\
& =13(1.40)^{3}(14)+2(0.606)(12.75-1.40)^{2}=169 \mathrm{in} .4
\end{aligned}
$$

The bending stress

$$
\mathrm{S}_{\mathbf{s}}=\mathrm{Mc} \text {, }
$$

$$
S_{I_{\text {max }}}=10 \underline{W Z}\left(b_{2} x\right) I_{x}+5 \underline{W Z}\left(b_{2} v: I_{y} .\right.
$$

Since $/ \mathrm{XX}=I_{y}, \mathrm{~b}_{2 x}=\mathrm{b}_{2 y}=\mathrm{b}$

$$
\begin{aligned}
S_{\Delta_{\text {max }}} & =! W W Z b_{2} I(1.5) \\
& =10(1350)(10.5)(11.75)(1.5) 169=14,300 \mathrm{psi} .
\end{aligned}
$$

where $W=$ weight of cask plus contents, $1350 \mathrm{lb}$. 
The Eirect iensile stress. Sr. is equally divided between the four bolts

$$
S_{T}=2 W 4 A_{r}=2(1350) 4(0.606)=1114 \text { psi. }
$$

The shearing stress. $S$, is also equally divided between the four bolts. The resultant. P. of the 5 and $10 \underline{\mathrm{W}}$ loads is

$$
P=\left[(10 \underline{W})^{2}+(5 W)^{2}\right]^{2}=11.18 W
$$

and

$$
S_{s}=P 4 A_{s}=11.18(1350) 4(0.785)=4800 \text { psi. }
$$

where $A_{3}=$ shear area (full area) of 1 in. by $8-\mathrm{NC}$ bolt, $0.785 \mathrm{in}^{2}$.

From Mohr's circle of stress.

$$
\begin{aligned}
S_{\max } & =S_{r}+S_{s} 2+\left[\left(S_{r}+S_{s} 2\right)^{2}+\left(S_{s}\right)^{2}\right]^{12} \\
& =7707+\left[(7707)^{2}+4800^{2}\right]^{12}=16.800 \text { psi. }
\end{aligned}
$$

Since these stresses are beiow those shown in Table 2.1. the tie-down system exceeds the requirements of the regulations when any grade of steel bolt is used.

\section{5 .2 Tie donn of cask to vehicle}

The wire rope can pull against the ensset (see Fig. 3.5) or the body of the risk. The force imposed on the cask and or the gusset y the wire rope tie-down is then determined. The vertical. forward, and transverse loads $, F_{z}, F_{x}$. and $\left.F_{y}\right)$ ere determined by assuming the tie downs are at a $45^{\circ}$ angle to the direction of travel and to the vertical direction. These loads will be added and compared to the strength of the weld holding the tir Jown to the cask. In the final calculation no additional credit is taken for the skid tie-downs.

Vertical luad application. The forces on the tie-down $\left(F_{z}\right)$ resulting from the application of a vertical load applied to the center of gravi:y of two times the weight of the package are found by a summation of the vertical forces (see Fig. 3.7).

$$
\begin{aligned}
& \mathbf{I} \mathbf{F}_{\mathrm{v}}=0,+=1 \\
& \mathbf{S}_{\mathrm{v}}=0=2 \underline{\mathbf{W}}-\mathbf{W}-2 \mathrm{~F}_{\mathrm{x}} \\
& \mathbf{F}_{z}=\mathbb{W} 2=15252=763 \mathrm{lb} .
\end{aligned}
$$




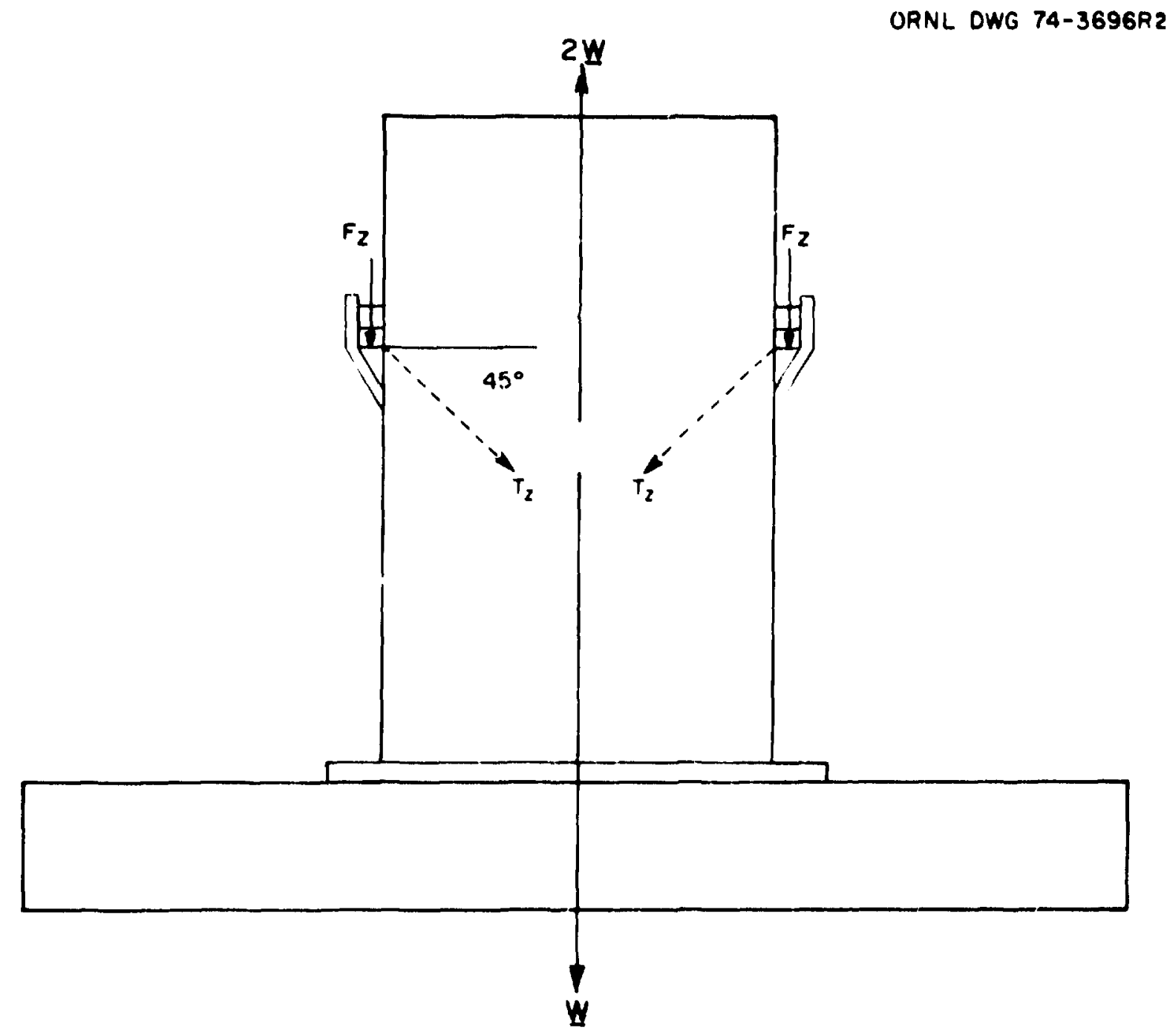

Fig. 3.7 Forces due to vertical thrust on OPNL Shipping Cask D-38. 
where

$\underline{W}=$ ask plus contents and skid weight (see Table 2.2.). $1525 \mathrm{lb}$.

The tension in the wite rope from the $2 \mathrm{~W}$ load is

$$
I_{z}=F_{z} 2\left(\sin 45^{\circ}\right)=763:(0.707)=540 \mathrm{lb} \text {. }
$$

Formard load application. The forces on the tie-dewn (Fs) resulting from the application of a horizontal force applied to the center of gravity in the direction of travel oi ten times the weight of the package are found by summing the horizontal forces (see Fig. 3.8).

$$
\begin{aligned}
& \mathbf{I F}_{\boldsymbol{n}}=0,+=- \\
& \underline{I} F_{n}=0=10 \mathbf{Y}-\mathbf{F x} \\
& F_{x}=10 \mathbb{X}=10(1525)=15.250 \text {. }
\end{aligned}
$$

The tension in the cable from the $10 \mathrm{~W}$ load is

$$
T_{x}=F_{x} 2\left(\cos 45^{\circ}\right)\left(\cos 45^{\circ}\right)=15.2502(0.707)(0.707)=15.250 \mathrm{lb}
$$

Transierse load application. The forces on the tie-down ( $\left.f_{y}\right)$ resulting from the application of a horizontal force applied to the center of gravity transverse to the direction of travel of five times the weight of the package are found by a summation of the forces in the iransverse direction (see Fig. 3.9).

$$
\begin{gathered}
\Sigma F_{T V}=0,+=- \\
\Sigma F_{T V}=0=5 \underline{W} \cdot 2 F_{y} \\
F_{y}=5 \underline{W} 2=5(1525) \cdot 2=3810 \mathrm{lb} .
\end{gathered}
$$

The tension in the cable from the $5 \mathrm{H}$ transverse load is

$$
T_{y}=F_{y}\left(\cos 45^{\circ}\right)\left(\cos 45^{\circ}\right)=3810(0.707)(0.707)=7620 \mathrm{ib} .
$$

Combined load application. The forces produced for the forward $\left(T_{x}\right)$, transverse $\left(T_{y}\right)$, and vertical $\left(T_{z}\right)$ applied loads may be added to determine the total tension in the tension member.

$$
T_{T}=T_{x}+T_{y}+T_{s}=15,250+7620+540=23,410 \mathrm{lb} .
$$




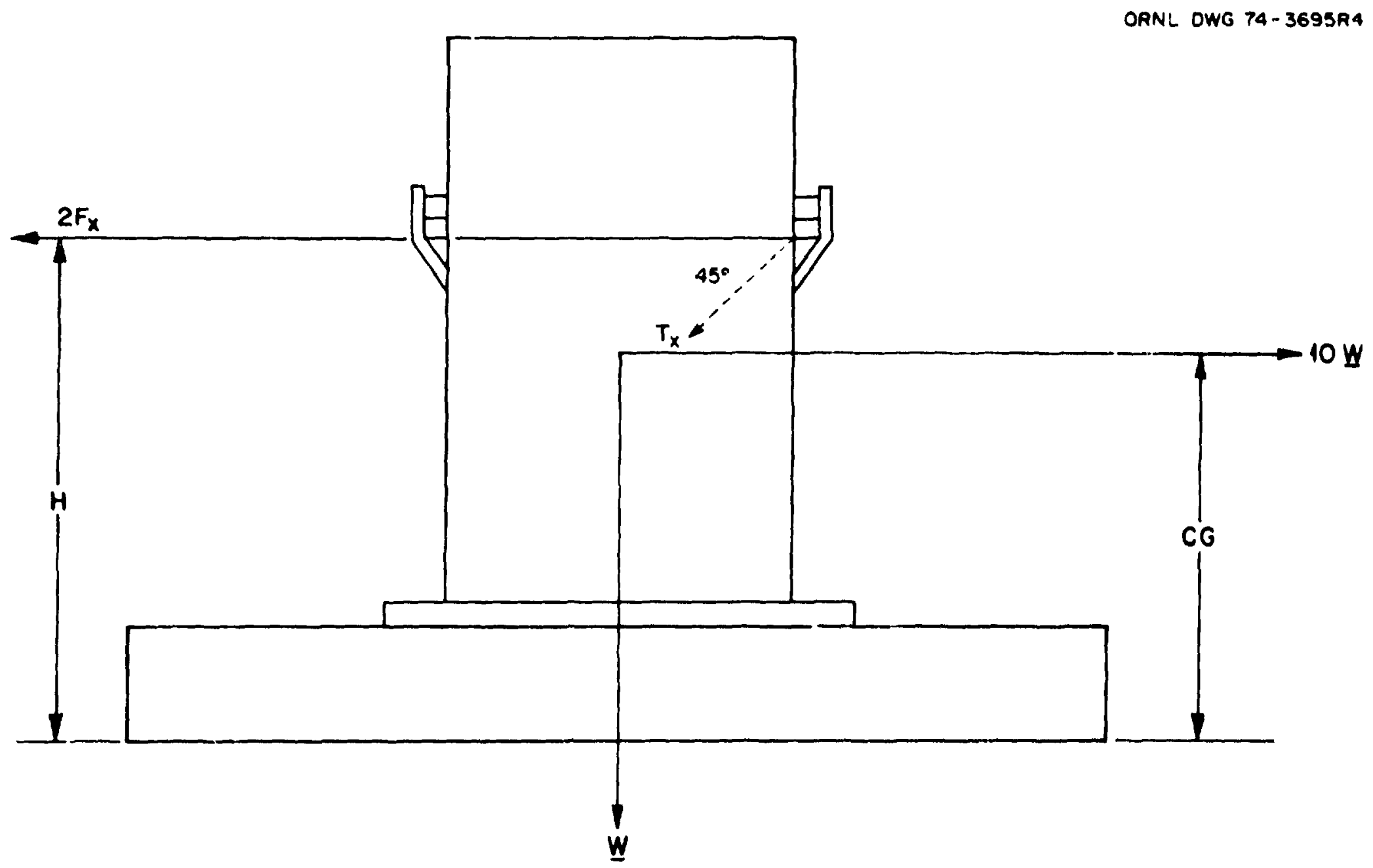

Fig. 3.8 Forces due to forward thrust on ORNL Sh1pping Cask D-38. 
ORNL DWG 74-3697R3

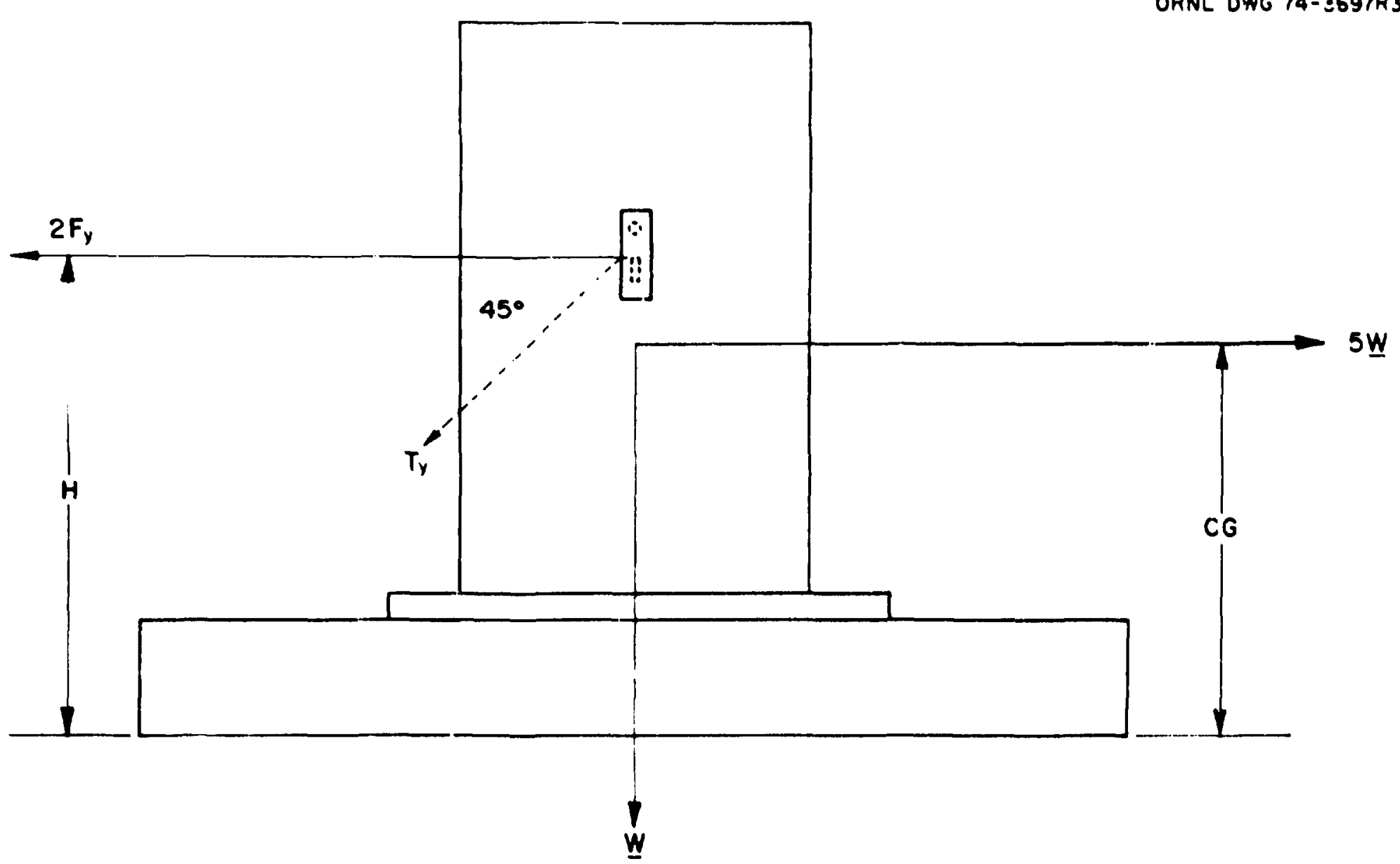

Fig. 3.9 Forces due to transverse thrust on ORNL Shipping Cask D-38. 
This load is applied to the cask body and to the weld holding the trunnion to the cask. The force applied to the weld is

$$
T_{\text {. }}=2 \mathrm{~T}_{r} \sin 45^{\circ}=(2)(23.410)(0.707)=33.100 \mathrm{lb} \text { 、 }
$$

The 5 16-in. fillet weld of the 2- by 3 8-in. bar to the cask (S-1 of Fig. 3.5) is 8 in. long. $l_{i}$ is capable (3000 lb allowable shear load per linear inch of weld $)^{19}$ of a shear load of 24,000$)$ lb.

The 3 16-in. fillet weld of the gusset to the casi (S-2 in Fig. 3.5) is 5.75 in. long. It is capable $(1800 \mathrm{lb} \text { allowable load per linear inch of weld })^{15}$ of a shear load of $10,350 \mathrm{lb}$.

The welus theiefore are capable of resisting a total force of $34.350 \mathrm{lb}$. The tie-downs impose a load of $33,100 \mathrm{lb}$ on the weld. The tie-downs are sufficiently strong to meet the requirements of the reguiations.

If the external support strap of the cask lifting trunnion were to pull out of the cask due to excessive loads, containment would not be lost. and the ability of the cask to meet otter reyuirements would not be impaired.

The lifting ear of the cavity closure plug is not strong enough to be used as a package tie down: therefore. a shroud is provided which securely covers this part during transport in such a manner as to present its use for that purpose. The shroud is held in place by nuts which have a sealed lockwire.

\section{STANDARDS FOR TYPE B AND LARGE-QLANTITY PACKAGING}

The structural standards for large-quantity packaging include load resistance of the packaging and the external pressure which the package must withstand. Compliance of the OR.NL Shipping Cask D-38 with these requirements is discussed in the following subsections.

\section{I Load Resistance}

When regarded as a simple heam supported at its ends along any major axis. the container must be capable of withstanding a static load normal to and uniformly distributed along its length that is equal to five times, its fully loaded weight; it should not generate stress in any material of the cask in excess of the yield strength of that material.

The equivalent cross section of the cask analyzed in this study is illustrated in Fig. 4.1.

The maxımum bending moment $(M)$ is at $L 2$.

$$
\begin{aligned}
M_{\text {max }} & =\left(R_{1} L / 2\right) \quad \omega / .^{2} / R \\
& =338(\times 20 / 2) \quad 338(20)^{2} / 8=16,900 \mathrm{in.} \mathrm{Ib.} .
\end{aligned}
$$

where $\omega=$ unit bending load in lbs per lineai in. 
ORNL-DWG 75-5280RI

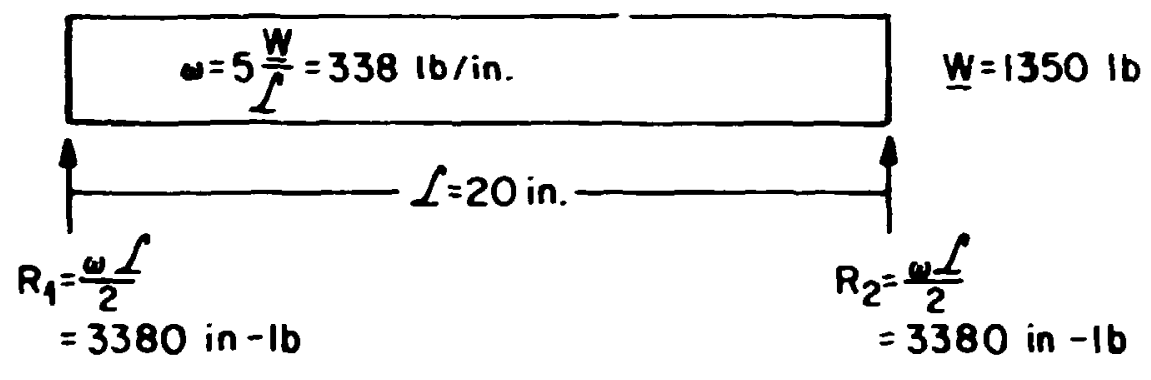

(o) CASK AS SIMPLE BEAM

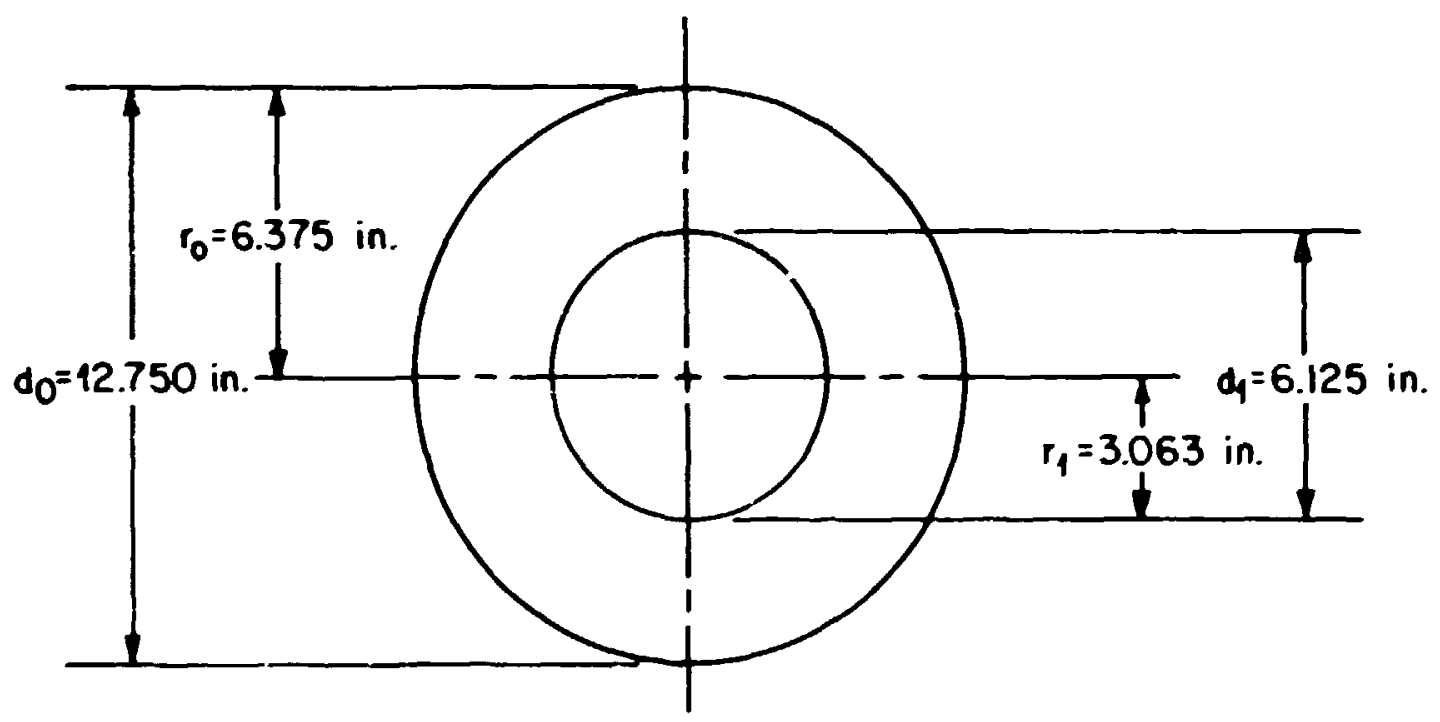

(b) EQUIVALENT CROSS SECTION OF CASK

Fig. 4.1 Analytical model to determine load resistance of ORNL Shipping Cask D-38. 
The momeni of irertia. $I$, of the cross section.

$$
\begin{aligned}
I & =\pi 4\left(r_{10}^{4}-r_{1}^{4}\right) \\
& =\pi 4\left(6.375^{4}-3.063^{4}\right)=1228 \mathrm{in} .
\end{aligned}
$$

The maximum bending stress. $S_{k}$ is

$$
S_{1}=M r_{n} l=16.900(5.375) 1228=88 \text { psi. }
$$

The maxinism horizontal shear. $S_{\text {s. }}$ occurs at each end of the neutral axis.

$$
\left.S_{s}=(4), R_{1} \pi\left(r_{0}^{2}-r_{1}^{2}\right)=(43) 3380(\pi) \times 6.375^{2}-3.063^{2}\right)=46 \mathrm{psi}
$$

The cask exceeds the requirements of the regulations from the standpoint of load resistance

\subsection{External Pressure}

The regulations require that the design of the shipping package be adequate to ensure that the containment vessel will suffer no loss of contents if subjected to an exterial pressure of 25 psig.

The shell of the containment vessel is evaluated from the standpoint of withstanding external pressure with reference to Paragraph CG-28 of the ASME Boiler and Pressure Vessel Code, ${ }^{16}$

$$
\begin{aligned}
& \text { L } d_{o}=124.75=2.52 \\
& d_{o} t=4.750 .125=39.5 .
\end{aligned}
$$

and the maximum allowable working pressure

$$
P_{a}=B D_{0} 1=950039.5=240.5 \text { psig. }
$$

where B -9500 (from Fig. UNF-28.8 on p. 232 of ASME Boiler and Pressure Vessel Coge. Appendix $V)^{18}$ Since the marimum allowable working pressure on the shell of the crntainment vessel exceeds 25 psig. it is concluded that the cask exceeds the regulation requiremeris of the structural standard for externa! pressure.

External pressure would load the flat ends of the stainless steel cladding. The maximurn thickness required for the end plates is calculated from the formula in Paragraph UG 34 of the ASME Boiler and Pressure Vessel Code: ${ }^{16}$ since the minimum thickness of either end plate is $0 . n_{0}$ inches, the externai container structure and the massive uranium shields provide sufficient support to prohibit significant deflection of the flat ends due to external pressure.

Gaskets have been used at differential pressures significantly greater than 25 psig and have been found to satisfy the requirements. Hence, the regulations are met. 


\section{COMPLIANCE WITH STANDARLS FOR NORMAL CONDITIONS OF TRANSPORT}

The regulations stipulate that a single packige must be able to withstand the normal conditions of transport without substantully reducing the effectiveness of the package and without reieasing radioactive material from the containment vessel. The contents of the container are limited so that the package will contain no gases or vapors that could reduce the effectiveness of the packagirg. To circulating coolant other than atmospheric atr is used. and no mechanical cooling device is required or provided. The OR.VL Shippirg Cask D-38 and its inner containers are designed so that the contents will not be vented to the atmosphere under normal conditions of iransport. These normal conditicas include the eiffects of heat, cold, pressure, free drop, and penetration.

\section{I Heat}

The package must be able to withstand direct sunlight at an ambient temperature of $: 30^{\circ} \mathrm{F}$ in still air without reducing the effectiveness of the pacis.ging. A modified version of the HEATING- $3^{17}$ coni, uter program was used to compute the steady-state temperature distribution in the cask and its contents under the specified conditions.

\subsubsection{Thermal properiies of materials}

The thermal properties of materials used to compute the temperature distribution are listed in Table 5.1.

\subsubsection{Thermal model}

The computational model representing the ORNL Shipping Cask D 38 is illustrated in Fig. 5.1. The contents were modeled as a homogeneous cylinder with the decay heat-generation rates of $20 \mathrm{~W}$ and $80 \mathrm{~W}$ uniformly distribured throughout the volume.

It was assumed that natural convection was a significant mode of heat transfer in the larger interio: air gaps. Natural convection was neglected in the remaining internal gaps. leaving radiation and conduction as the only modes of heat transfer across these gaps.

In calculating the steady-state temperature for the $130^{\circ} \mathrm{F}$ environment in direct sunlig.ht, it was assumed that a solar-heat flux of $144 \mathrm{Btu} \mathrm{hr} \mathrm{ht}^{-1}$ was incident upon the entire outer surface of the cask, and the fraction of the incident soiar flux that is alsorbed by the cask is equal to the absorptivity (0.6) of the outer surface of the cask. A second steady-state analysis assumed that the ambient temperature $u$ as $100^{\circ} \mathrm{F}$ and that the solar heat load was reduced to zero. 
Table 5.1. Thermal properties of materials of construction

\begin{tabular}{|c|c|c|c|c|}
\hline Material & $\begin{array}{c}\text { Temperature } \\
\left({ }^{\circ} \mathrm{F}\right)^{\mathbf{a}}\end{array}$ & 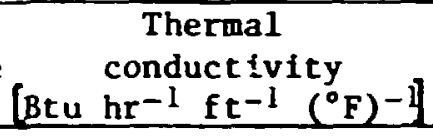 & $\begin{array}{l}\text { Density } \\
\left(1 \mathrm{~b} \text { in. }^{-3}\right)\end{array}$ & $\begin{array}{l}\text { Heat capacity } \\
\text { [Btu } 1 \mathrm{t}^{-1}\left({ }^{\circ} \mathrm{F}\right)\end{array}$ \\
\hline SS-304 & NTD & 9.4 & 0.29 & 0.12 \\
\hline Urantum & NTD & 19.0 & 0.683 & 0.028 \\
\hline Neoprene & NTD & 0.11 & 0.05 & 0.471 \\
\hline \multirow[t]{5}{*}{ Air ${ }^{b}$} & 0.0 & 0.013 & $4.97 \times 10^{-5}$ & C. 239 \\
\hline & 200.0 & 0.017 & $3.47 \times 10^{-5}$ & \\
\hline & 400.0 & 0.021 & $2 . \therefore 6 \times 10^{-5}$ & \\
\hline & 600.0 & 0.025 & $2.16 \times 10^{-5}$ & \\
\hline & 800.0 & 0.029 & $8.17 \times 10^{-6}$ & 0.256 \\
\hline Source & NTD & 31.8 & 0.0361 & 1.0 \\
\hline
\end{tabular}




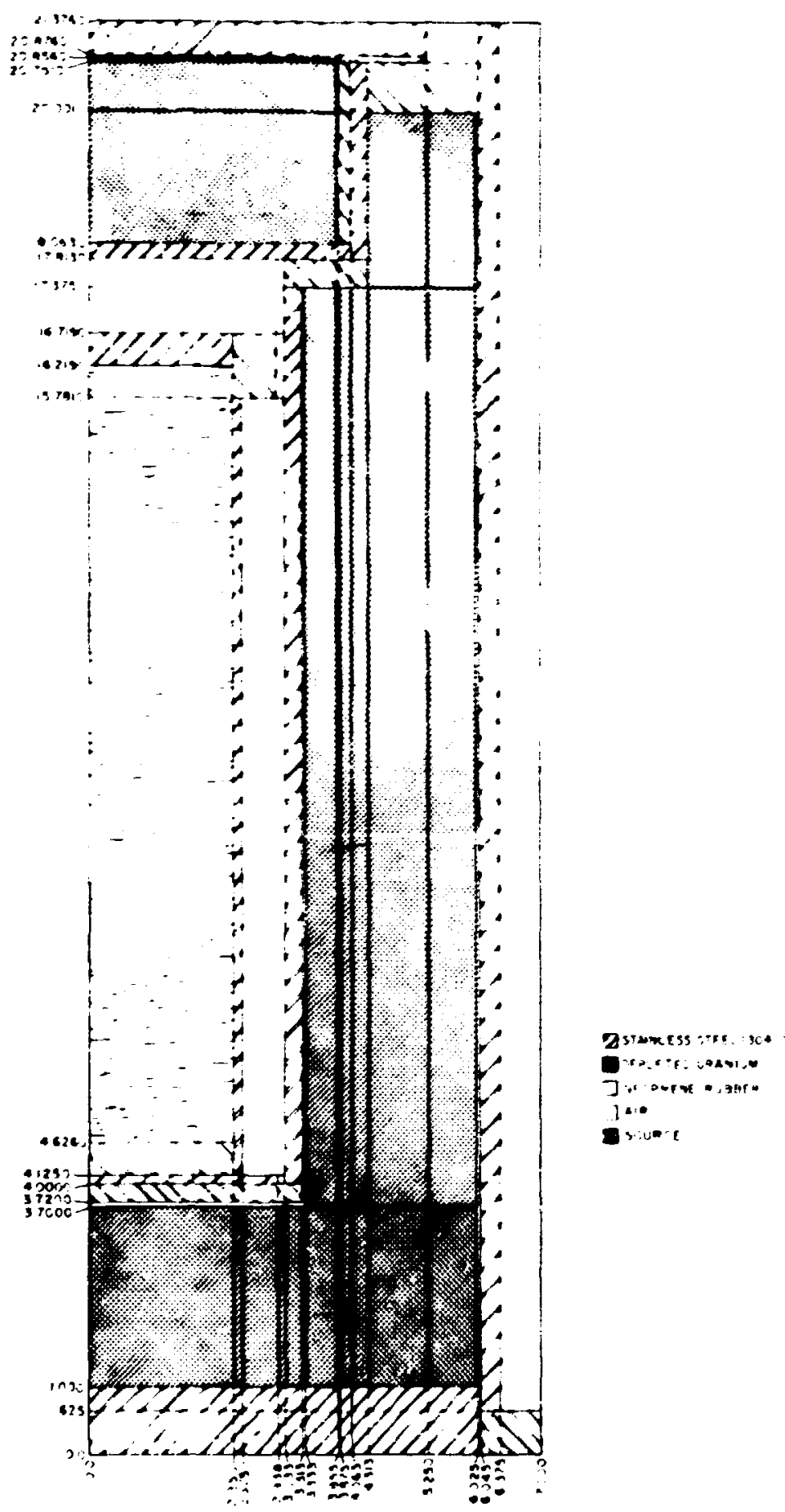

Fig. 5.1 Computational model to determine the effect of thermal tests on the ORNL Shipping Cask D-38. 


\subsubsection{Maximum temperature}

Calculated temperatures of points of interest throughout the cask are presented in Table 5.2 for the $130^{\circ} \mathrm{F}$ ambient plus solar-heat load case as well as for the $100^{\circ} \mathrm{F}$ ambient-shade case.

The maximum accessible external surface temperature for the $100^{\circ} \mathrm{F}$ ambient no-solar-heat-load case and using the 80-W approved litnit for the cask was found to be 16. F. When the internal heat load was reduced to $20 \mathrm{~W}$. the maximum external temperature was $121^{\circ} \mathrm{F}$. Since this is less than the $122^{\circ} \mathrm{F}$ limit specifial by the DOT regulations." the rontainer does not require exclusive use shipping conditions. However. berween 20 and $80-\mathrm{W}$ loadings, when the external temperature exceeds $122^{\circ} \mathrm{F}$. the container must be shipped in a transport vehicie consigned for the sole use of the consignor. Under these conditions the container complies with the regulations.

For the $130^{\circ} \mathrm{F}$ ambient solar-heat load case with an internal heat load of $80 \mathrm{~W}$. the maximum calculated temperature of the inner container seal was $290^{\circ} \mathrm{F}$. that of the neoprene gasket which forms the closure seal was $242^{\circ} \mathrm{F}$, and that of the ${ }^{\circ} \mathrm{O}^{-}$ring drain seal was $247^{\circ} \mathrm{F}$. Since these temperatures are well within the operating limits of the gaskets and seals. the integrity of the cask and its inner container will be unaffected by these thermal boundary conditions. Therefore, the container complies with the regulations.

\subsection{Cold}

The shipping package must be able to withstand an ambient temperature of $-40^{\circ} \mathrm{F}$ in still iir and shade.

If $T_{I}=-40^{\circ} \mathrm{F}\left(420^{\circ} \mathrm{R}\right)$, and assuming no internal heat load. the final or maximum pressure ( $\left.P_{:}\right)$in any cavity sealed at a pressure of 14.7 psia and a :emfirature of $70^{\circ} \mathrm{F}\left(530^{\circ} \mathrm{R}\right)$ is:

$$
P_{2}=\left(P_{1} T_{2}\right) T_{1}=11.65 \text { osia. }
$$

The resulting pressure differential is less than the 25 -psig differential pressure investigated in Sect. 4.2. A temperature of $-40^{\circ} \mathrm{F}$ is within the operating temperature range of the seals and the stainless steel cladding. strictural components, and fasteners. Brittie fracture of these components under the stipulated cold condition i., not likely because the temperatures of these componenis are above their ductile-to-brittie transition temperatures.

The preceding considerations indicate that the stipulated cold conditions will not reduce the effectiveness of the packaging, and that the container conforms to the requirements for the cold condition of normal transport.

\subsection{Pressure}

The regulations for normal conditions of transport specify that the package should be able to withstand an atmospheric pressure of 0.5 times the standard atmospheric pressure, with the resulting pressure being 7.35 psia. 
Table 5.2. Maximum temperatures as a result of computer evaluation of thermal test

\begin{tabular}{lcc}
\hline & $\frac{\left.\text { Internal heat load ( }{ }^{\circ} \mathrm{F}\right)}{80 \mathrm{~W}}$ \\
\hline $100^{\circ} \mathrm{F}-$ No solar-heat load & & \\
Inner container seal & $20 \mathrm{~W}$ & 138 \\
External temperature (max) & 165 & 121 \\
$130^{\circ} \mathrm{F}-$ Ambient solar-heat load & & \\
Inner container seal & 290 \\
Neoprene gasket closure seal & 242 \\
"O" ring drain seals & 247 \\
\end{tabular}

When the model is under full-heat load, trapped air in the cavity will expand and exer internal pressures. Assuming assembly at $70^{\circ} \mathrm{F}$ and 14.7 psia. the resulting pressure of any trapped air is:

$$
P_{2}=\left(P_{1} T_{2}\right): T_{1}=(14.7)(750): 530=20.8 \text { psia }(13.4 \text { psig })
$$

where

$$
\begin{aligned}
& P_{1}=\text { assembly pressure. } 14.7 \mathrm{psia}, \\
& T_{2}=\text { temperature under heat load. } 750^{\circ} \mathrm{R}\left(290^{\circ} \mathrm{F}\right) . \\
& T_{1}=\text { assembly ternperature, } 530^{\circ} \mathrm{R}\left(70^{\circ} \mathrm{F}\right) .
\end{aligned}
$$

The cask and its gasketed seals will be able to withstand this pressure without damage or reduction in effectiveness of the packaging, and the container conforms to the requirement for the reduced pressure condition of normal transport (see Sect. 4.2.).

\subsection{Vibration}

The container is of weided construction and, therefore. vibrations received in transit are not expected to aiffect the integrity of the cask. In addition, the cask, which was built severai years ago, has operated in the transportation environment and has suffered no ill effects as a result of the vibrations that were encountered. 


\subsection{Water Spray}

The containment capabilities of the ORNL Shipping Cask D-38 are not compromised by water spray, since all external surfaces are of stainless steel. The closure seal is impervious to water.

\subsection{Free Drop}

The regulations for normal conditions of transport require that a package weighing less than $10,000 \mathrm{lb}$ shall be capable of withstanding a free drop through a distance of $4 \mathrm{ft}$ onto a flat. essentially unyielding. horizontal surface. strikıng the surface in a position in which maximum damage is expected to result. A free drop of the GR.NL Shipping Cask D-38 through a distance of $4 \mathrm{ft}$ is expected to produce only minor denting of the outside steel shell. If the package were dropped flat on its top. repairable extemal damage would occur; however. the effectiveness of the package would not he reduced. (See the analysis of the 30 -ft free fall. Sect. 6.1).

\subsection{Penetration}

The regulatiens for normal conditions of transport stipulate that the package must be capable of withstanding the impact of the hemispherical end of a vertical steel cylinder that weighs $13 \mathrm{lb}$. has a $1-14 \mathrm{in}$. diam, and is dropped from a height of 40 in. onto the exposed surface of the package that is expected to be the most vulnerable to puncture.

Tests have been conducted on similar type shipping casks and the results indicate that the effectiveness of the stainless steel jacket will not be reduced. (See appendix 12.7).

\subsection{Compression}

The package must be able to withstand the greater of two compressive loads equal to either five times the weight of the package or $2 \mathrm{lb}$ in. ${ }^{2}$ multiplied by the maximum horizontal cross section of the package. The load shall be applied unifurmly against the top and bottom of the package for $24 \mathrm{hr}$ in the position in which the package would normally be transported.

The stress, $\mathrm{S}_{\mathrm{m}}$, is created in the steel shell by a weight imposed on the head of five times the weight of the package. This is determined:

$$
S_{m}=S(W) \pi(d)(T)=5(1350) \pi(12)(0.38)=470 \text { psi }(<15.000 \text { psi }) .
$$

where

$$
\begin{aligned}
& \underline{W}=\text { weight of fully loaded container, } 1350 \mathrm{lb} . \\
& d=\text { diameter of container, } 12 \mathrm{in} . \\
& T=\text { thickness of container shell. } 0.38 \mathrm{in} .
\end{aligned}
$$


The stress, $\mathrm{S}_{\boldsymbol{n}}$ created in the steel shell by a pressure of 2 psi on the he $\rightarrow$ is determined:

$$
\left.S_{,}=2\left(\pi d^{2}\right) 4 \pi\right)(d \times T)=2\left(\pi \times 12 !^{2} 4(\pi \times 12 \times 0.38)=16 \text { psi }(<15.000 \text { psi })\right. \text {. }
$$

The stress devetoped in the shell by the imposed weight of five times the package weight of 470 psi was greater than the potential stress. and it did not exceed the strength of the shell of the container. No cre'': for the additional strength resulting from the uranium cask filling was taken.

\section{COMPLIANCE WITH STANDARDS FOR HYPOTHETICAL ACCIDENT CONDITIONS}

The standards for the hypothetical accident conditions stipulate that a container used for the shipment of fissile or large quantities of radioactive material shall be designed and coisitructed in such a manner and its contents limited so that. if i: is subjected to the specified free drop. puncture. thermal, and water immersion conditions. the following conditions would be met:

1. The reduction in shielding would not be sufficient to inarease the extemal radiation dose rate to more than $1000 \mathrm{mR}$ hr at a distance of 3 ft from the outside surface of the package.

2. No radioactive material would be released from the package except for gases containing total radioactivity not to exceed $0.1 \%$ of the total radioactivity of the conterits of the package.

3. The contents would remain subcritical.

\subsection{Free Drop}

The first in the sequence of hypothetical accident conditions to which the cask must be subjected is a free drop of $30 \mathrm{ft}$ onto a hat, essentially unyielding, horizontal surface. striking the surface in a position in which the maximum damage is expected to occur.

Damage to the ORNL Shipping Cask D-38 was evaluated by assuming the cask struck the unyielding surface in one of three different orientations. These included impact on: (1) the top corner. (2) the top end. and (3) the side.

\subsubsection{Impact on rop comer}

A computational analysis (see Appendix 12.3) was applied to a simplified cylindrical cask model to estimate the deformation resulting from a 30-ft corner drop (see Fig. 6.1) with its line of action through the senter of gravity. Results shown in Table 6.1 indicate that by using 
ORNL DWg ?4-8017 R2
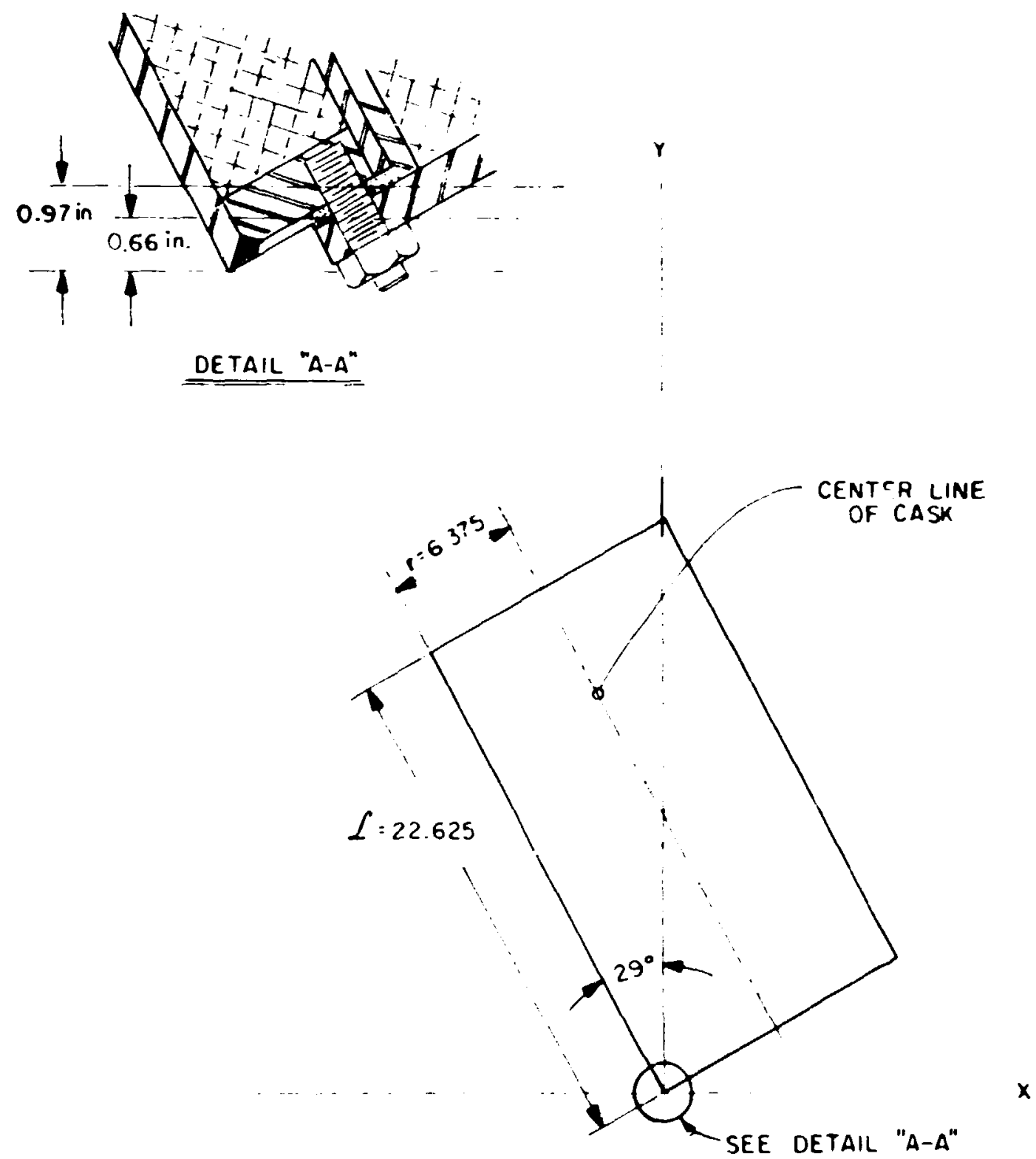

Fig. 6.1 Deformation geometry for corner impact orientation of cask. 
specific energies for stainless steel that vany from 100,000 to 260,000 in.-ib in. ${ }^{3}$, the deformation would vary from 1.0 t.s 0.7 in.: this deformation would occur primarily in the steel because of the large bearing area between the steel and the uranium.

When the cask impacts on its top corner with its line of action through the center of gravity. the studs holding the inner cavity plug. the comer of the inner cavity plug flange. and the corner of the cask will all contact the unyielding surface at essentially the same instant. assuming that the steel shroud is neglected. Neglecting the strength of the steel shroud is justified because it is thin. will readily collapse. and is not designed to resist impact forces. As a result, the nange, and, therefore, the inner cavity closure plug will be jammed back into its cask cavity before motion of the plug relaire to the cask body can impose a significant load on the studs in tension. In addition. the studs cannot be loaded in shear because of the small clearance that exists between the cask body cavity and the plug. Deformation of the corner of the cask is expected to displare the top steel plate of the cask to further lock the closure plug in place. Because of this combination of effects. the total deformation of the top curiner of the cask is expected to be less than that shown in Table 6.1.

It is concl'jeed that the inner ca: ity plug will remain in place if the cask were to drop on its top corner when the line of artion is through the center of gravity.

Table 6.1. Impact on top correr - maximum acceleration and

deformation resulting from high and low values of spectfic energy in stainless steel

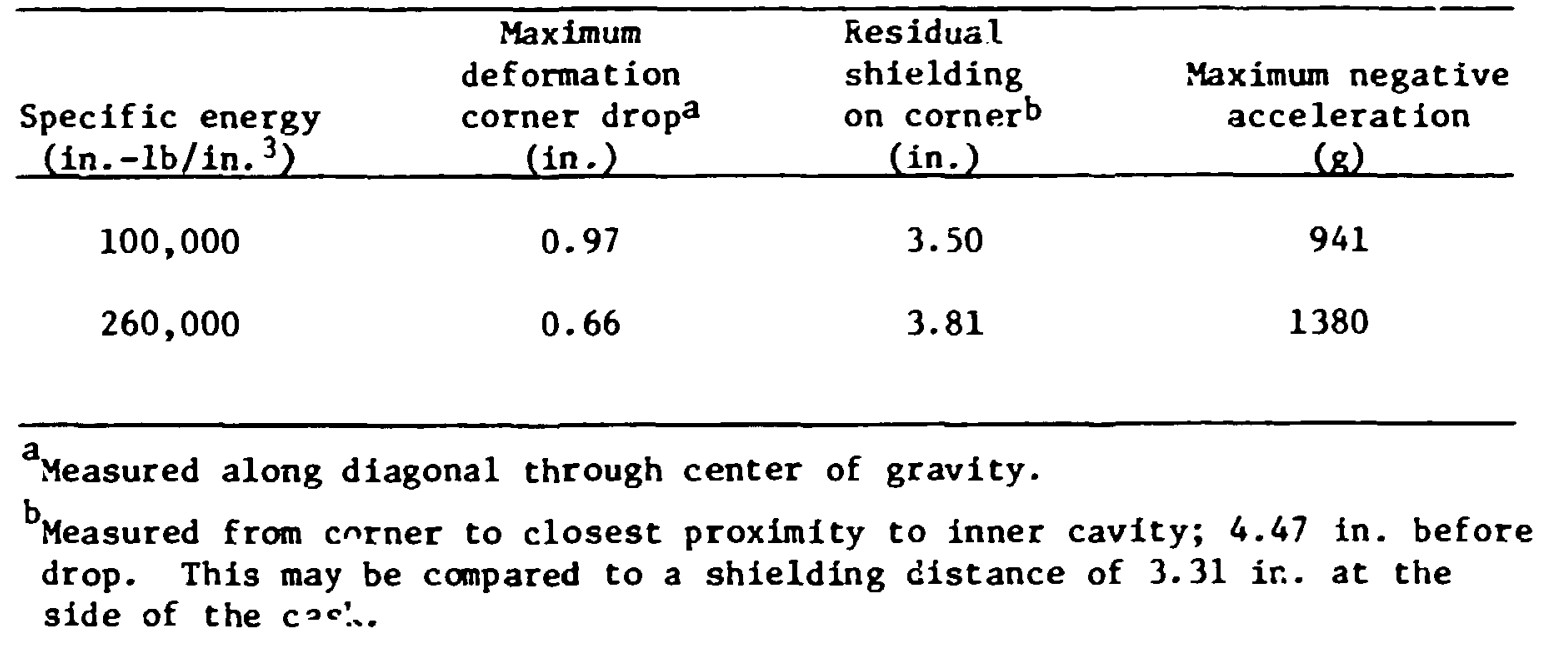




\subsubsection{Impact on top end}

The effect of a 30 -ft free fall onto the flat top of the cask was investigated to determine whether the cast uranium would fracture.

A computational mudel of the top end-impact orientation of the cask and idealized stress-strain curves for the two materials. stainless steel and uranium. that are involved are shown in Fig. 6.2. Eyuations are written for the idealized curves in the slope intercept form of a stra'ght line.

$$
\begin{aligned}
& S=m_{t}+S_{0} \\
& t=S-\left(S_{0} \mathrm{~m}\right)
\end{aligned}
$$

where

$$
\begin{aligned}
& S_{0}=\text { the } S \text { intercept lapproximate yield stress) of the line. } \\
& m=\text { the slope of }\left(S \text { ultimate }-S_{n}\right)+\text { ultimate, } \\
& =\text { strain. }
\end{aligned}
$$

For the stainless stcel cladding or outer shell.

$$
c=S-40.000 \text { psi } 80.000-40.0000 .50=1.25 \times 10^{-5} S-0.50
$$

For the uranium biological shield:ng.

$$
\epsilon=S-25,00090.000-25.0000 .13=2 \times 10^{-6} \mathrm{~S}-0.05
$$

It was assumed that stress in the column of uranium varies only with time and position. or stated mathematically. $S=\{(T X)$. It was further assumed that the stress in the 0.63 -in.-thick stainless-steel-top plate varies only with time: that is. the stainle.s steel was assumed to be weightless and $S=f(T)$. With this assumption, the compressive stress in the stainless steel, $S_{\text {sts. }}$ is equal to the stress in the uranium at $X=l$. the point of maximum stress. $S_{m}$. in the uranium. To simplify the mathematics without affecting the accuracy, the arca. $A$, was assumed to be unity. The kinetic energy of the cask must be stored in the uranium body and the stainless-steel-top plate in the form of strain energy.

$$
\begin{aligned}
& \mathrm{u}=\frac{1}{2} M u^{2}=\underline{W h}=A \rho l \cdot h=\int F_{u} d s_{u}+F_{s s t} \Delta \\
& =\int_{l=0}^{L=20.1} S_{11} A(\epsilon d x)+S_{s i t} A(\in t) \text {. }
\end{aligned}
$$

$S X=S_{m} I$.

$$
S=i_{m} \times l .
$$


ORNL Ung 69-9581 R2

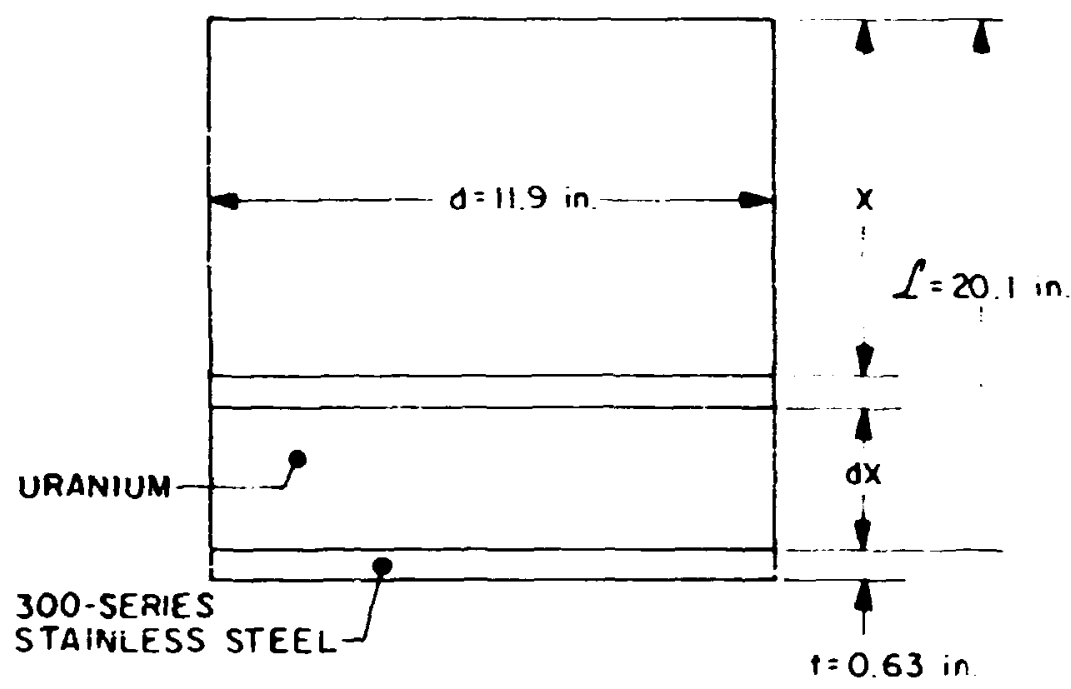

(a) MODEL

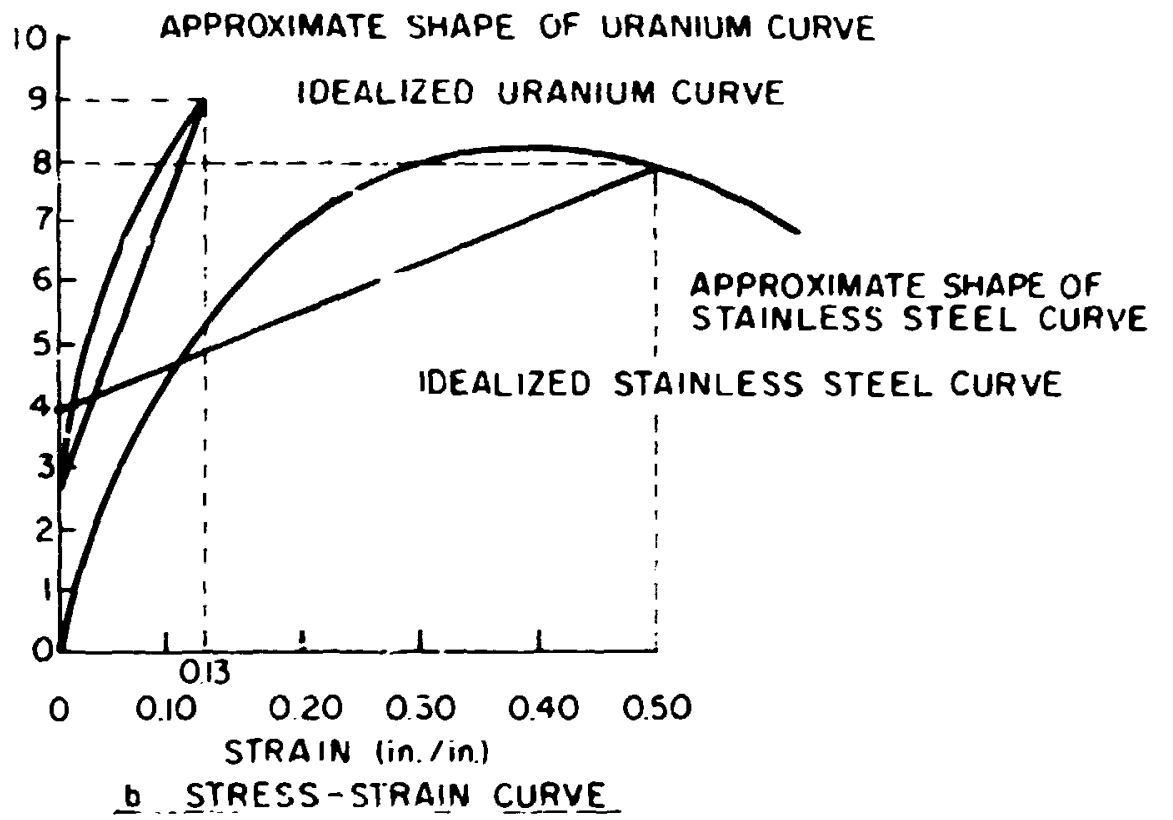

Fig. 6.2 Computational model of the top-end impact orientation of cask. and idealized stress-strain curves for uranium and stainless steel. 
Substituting for $S$ and $t$ and dropping $A=1$ and $t=1$. the strain energy,

$$
\begin{aligned}
& u=\int_{X=t=0}^{X=t=20.1}\left[\frac{S_{m} X}{L} \frac{2 S_{m} X}{L} 110^{-6}, 0.05\right] d X+S_{m} \mid 1.25 S_{m}\left(10^{-5}, \quad c .501\right. \\
& =\int_{X=l=0}^{X=L=20.1}\left[\frac{2 S_{m}^{2} X^{2}}{L^{2}}\left(10^{-6}\right) \cdot 0.05 \frac{S_{m} X}{L}\right] d X+1.25 S_{m}^{2} \cdot 10^{-3}, 0.5 S_{m}
\end{aligned}
$$

In:egrating.

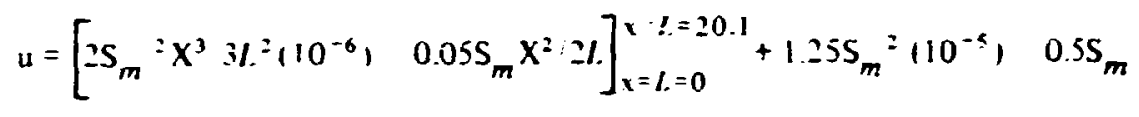

Substituting values

Simplifying.

$$
1(20.1)(0.61) 360=23 \mathrm{~S}_{m}^{2}(20.1) 10^{-6}-0.052 \mathrm{~S}_{m}(20.1)+1.25 \times 10^{-5} \mathrm{~S}_{m}^{2}-0.5 \mathrm{~S}_{m} .
$$

$$
S_{m}^{2}-\left(3.87 \times 10^{6}\right) S_{m}-1.74 \times 10^{2}=0 \text {. }
$$

and solving the equation. we find

$$
S_{m}=42.800 \text { psi. }
$$

Since the maximum siress. $S_{m}$. is less than the ultimate stress for uranium (sec Fig. 6.2), it is concluded that the uranium biological shield will not fracture as a result of the cask impacting on either of its flat ends nor will there be any damage to the shield that could be considered harardous.

\subsubsection{Impact un side}

Impact on the side of the cask such that the edge of the skid and the top cover of the cask hit the immovable surface simultaneously (Fig. 6.3) will allow most of the studs to be loaded in tension. The impact forces will be dissipated in bending the skid and deforming the steel corner of the cask. Neglecting the energy absorber in berding and deforming the skid and assuming all energy is dissipated by deforming the stainless steel in the comer of the cask. a computer analysis was made (see Appendix 12.4) to determine the negative acceleration rates and resultant deformations. Results shown in Table 6.2 indicate that by using specific energies of stainless steel which vary frem 100.000 to 260.000 in.-1b in.' (see Tahle 2.1), the deformation would vary from 1.1 to 0.7 in.: from Detail A-A it can be seen that this deformation would occur principaliy in the stcel. thus tending to confirm the original assumption.

It will be assumed that the larger calculated negative accelerations will act on the inner cavity plug. The following calculations demonstrate that the bolts are sufficiently i:song in hold the plug. 


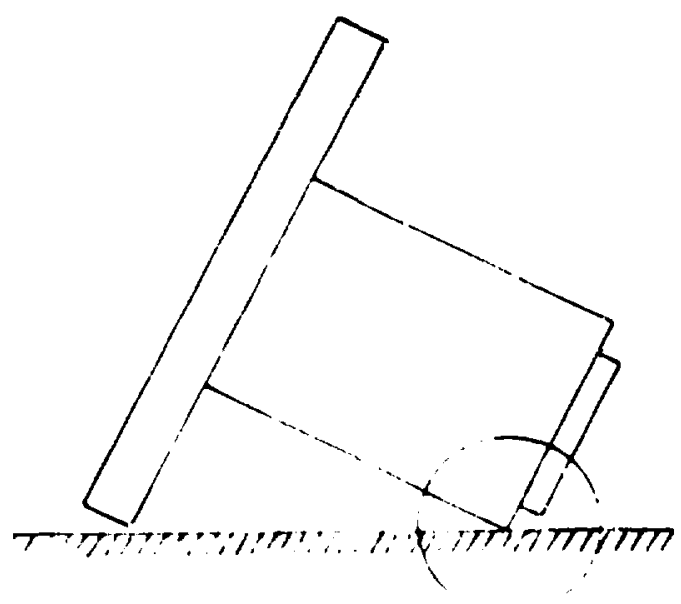

SEE DETAIL "A.A"--.-

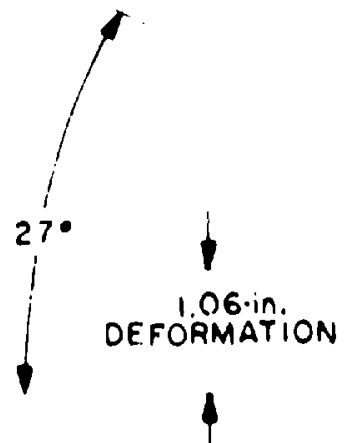

DEFORMATION

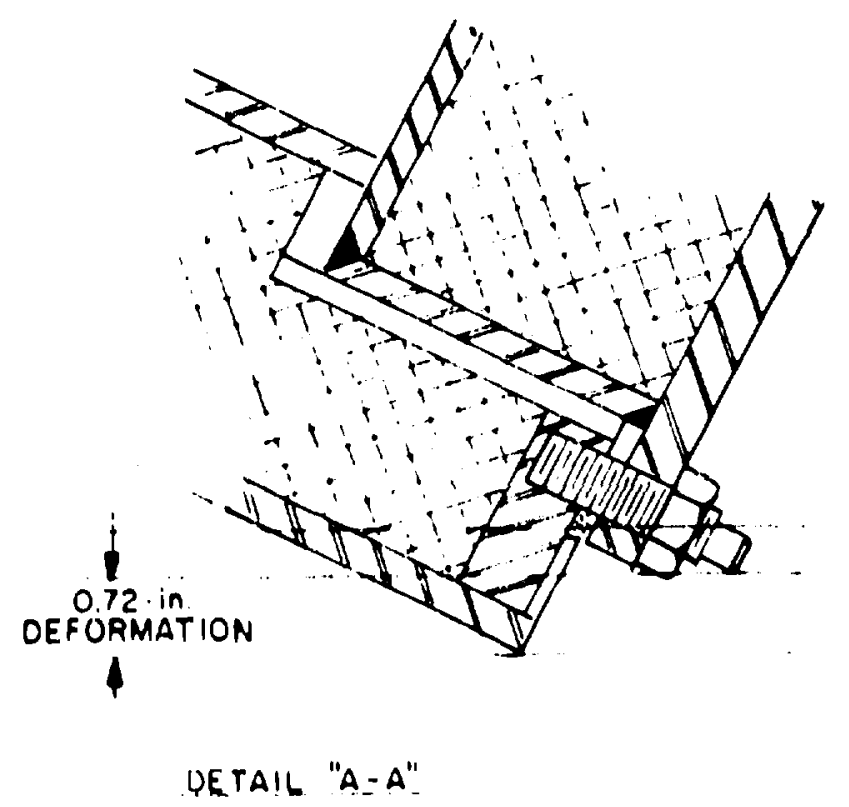

Fig. 6.3 Deformation gumetry for slde inpact orlentation of cask. 
Table 6.2. Impact on side - maximum acceleration and deformation resulting from high and low values of specific energy in ctainless steel

\begin{tabular}{cccc}
\hline Specific energy & $\begin{array}{c}\text { Maximum } \\
\text { deformation } \\
\text { side drop } \\
\text { (in.-1b/min. })\end{array}$ & $\begin{array}{c}\text { Kesidual } \\
\text { shielding } \\
\text { on cornera } \\
\text { (in.) }\end{array}$ & $\begin{array}{c}\text { Maxinum negative } \\
\text { acceleration } \\
\text { (8) }\end{array}$ \\
\hline 100,000 & 1.06 & $j .37$ & 852 \\
260,000 & 0.72 & $3 . j 2$ & 1262
\end{tabular}

Measured from corner to closest proximity to inner cavity, 4.47 in. before drop. This nay be compared to a shielding distance of $3.3 i$ in. at the side of the cask.

I sing lite laizest decelerztion in Table 6.2 and applying it to the weight of the cast lid $2=0$ coner.ts, the lurce. $F_{p}$. on the eighteen 12 -in. stud, holding the shielding plug is devermined as thillows:

$$
F_{p}=\underline{u}, x_{g}=200 \times 1262=252.400 \mathrm{lh} .
$$

where

$\underline{u_{s}}=\mathbf{u e g h t}$ :ff plug plus contents of inner cavity. $200 \mathrm{th}$.

$8=$ deceicralinn. 1262

The torce. 1, is applied to the cask :n the divetion of the drop. ithe compor :nt. Fa. of that force applies a'ong the axis of the inolis and the plugs is found as follou.

$$
F_{1}=F_{p} \sin \theta=252.400(0.457)=115.000
$$

where

$A=$ angle metueen line of studs and impact surface. 27

Sixteen of the stud. have an unengaged kngth of $1-38$ in. ard the other tho hase an uncngaged length of $5 \times$ in. Fach of the it long studs has a 4 -in. washer that has a cross-iectional area of $0.142 \mathrm{in}:$. " which is the same area as that of the stud. From an energ? 
storage standpoint, this additional area increases the effective length of the long studs to 2-1 8 in. The studs are made from annealed $4 ! 40$-series steei that has the idealized stress-strain curve shown in Fig. 6.4." It is assumed that the two short studs will fall in tensicr.

The force, $F_{s}$ that is required in the shor studs to cause fi.ilure is found:

$$
F_{s}=2\left(S_{u} K A\right)=2(90.000)(0.142)=25.600 ! b
$$

The elongation. $\Delta$, of the short studs at failure is found:

$$
\Delta=\epsilon L=0.27(0.625)=0.169 \text { in }
$$

At that time ine long studs have elongated by the same length and the strain is determined by

$$
\epsilon=\Delta L=0.1692 .125=0.080 \text { in. in. }
$$

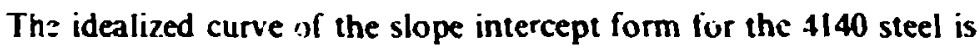

$$
\begin{aligned}
& S=m \epsilon+S_{v p} \\
& S=(90.000-63,000,0.27) \epsilon+63,000=100,000 \epsilon+63,000 .
\end{aligned}
$$

The stress in the remaining long studs is

$$
S=100.000(0.080)+53,000=71.000 \mathrm{psi} \text {. }
$$

The force. $F_{l}$. which the long studs will resist without further elongation is found

$$
\begin{gathered}
F_{L}=16(71,000)(0.142)=161,00 \mathrm{lb} . \\
F_{L}+F_{S}=161,300+25,600=186,900 \mathrm{lb}>115.000 \mathrm{lb} .
\end{gathered}
$$

Since the sum of the bicce required to break the two short studs plus the force which can be carried by the long studs is less than the force applied to the studs [see Eq. (65).], it is concluded that the inner cavity plug will remain fastened to the cask in the side drop.

\subsection{Puncture}

The second in the sequence of hypothetical accident conditions to which the cask must be subjected is a free drop of $\mathbf{4 0} \mathrm{in.}$ to strike, in a position in which maximum danage is expected, the top end of a verical mild steel bar mounted on an essentially unyielding horizoritai ,urface. The mild steel bar shall have a diameter of 6 in., with the top horizontal 


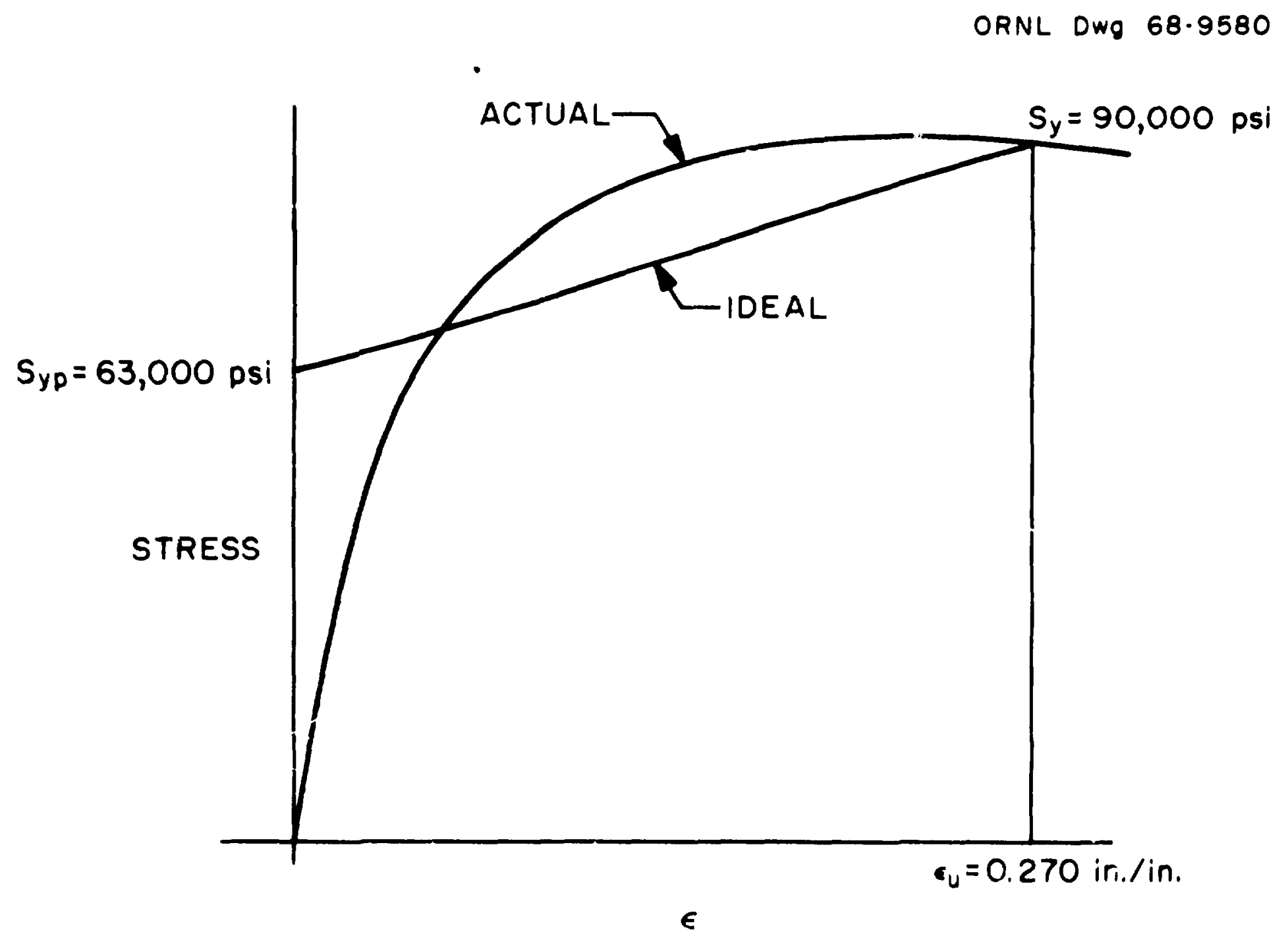

Fig. 6.4 Stress-strain curve for annealed 4140-serles steel. 
and its edge rounded to a radius of not more than 14 in.: the bar shall be of such lerigth that it will cause maximum damage to the cask, but not less than 8-in. long. The long axis of this bar shall be normal to the surface of the cask upon impact.

To analyze the puncture accident, a rather conservative model can be used that assumes all the energy absorbed by the cask is absorbed by the outer stainiess steel shell with no consideration being given to the uranium shielding.

The energy of impact will be absorbed by the 0.41 -in.-thick cask stainless steel outer shell. Figure 6.5 illustrates the configuration for this computational model. The absorbed energy, $\mathrm{C}$, is found:

$$
U=\underline{W} h=1525(40)=61.000 \text { in. }-1 b
$$

where

$$
\begin{aligned}
& \frac{W}{h}=\text { weight of cask, } 1525 \mathrm{lb} . \\
& h=\text { drop height, } 40 \mathrm{in} .
\end{aligned}
$$

The maximum energy imparted to the cask is 61,000 in.-lb. Conservatively, 100,000 in.-lb is required to deform 1 in. $^{3}$ of stainless steel (see Table 2.1); therefore. the energy of impact would deform about 0.61 in. $^{3}$ of material. When the cask strikes the bar, the depth of penetration of the stainless steel shell would not exceed the depth of a sector having a volume of 0.61 in. $^{3}$ The area, $\mathbf{A}$, of the displaced segment of the stainless steel shell is given by:

$$
A=V d=0.616=0.102 \text { in. }^{2} \text {. }
$$

where

$$
d=\text { diameter of bar, } 6 \text { in. }
$$

The height of the displaced segment of the stainless steel may be found by solving the following equation for $h$.

$$
A=r^{2} \cos ^{-1}(r-h r)-(r-h)\left(2 r h-h^{2}\right)^{1 / 2}
$$

where

$$
\begin{aligned}
& h=\text { height of segment (or depth of penetration), in., } \\
& r=\text { radius of cylinder. } 6.375 \text { in. }
\end{aligned}
$$

The depth of penetration is found to be 0.019 in. Damage of th:s magnitude would not reduce the effectiveness of the cask. 


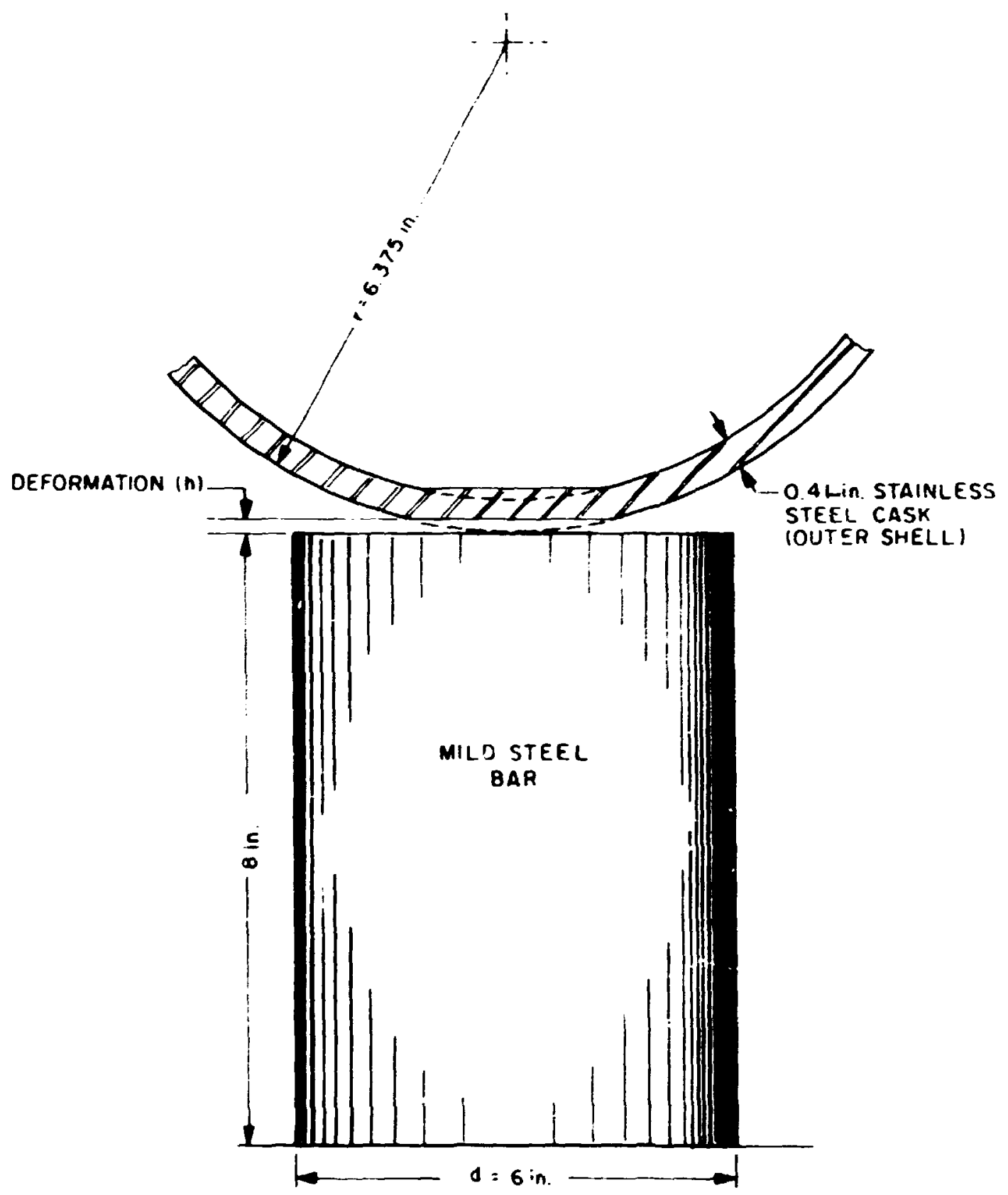

Fig. 6.5 Model used for puncture analysis. 


\subsection{Thermal Evaluation}

\section{3. : H.pothetical thermal accident condition discussion}

The third in the sequence of hypothetical accident conditions specified by the regulations to which the cask must be subjected is exposure for $30 \mathrm{~min}$ within a source of radiant heat having a temperature of $1475^{\circ} \mathrm{F}$ and an emissivity coefficient of 0.9 . or equivalent. For calculational purposes. It shall be assumed that the package has an absorption coefficient of 0.8. The package shall not be cooled artificially until after the 30-s.in test period and the temperature at the center of the package has begun to fall, or until $3 \mathrm{hr}$ iollowing the test period.

A modified versiun of the computer program, HEATING-3, " was used to determine the temperature distribution of the cask when it is exposed to these thermal environments.

It was assumed that the container was loaded with the maximum permissible decay heat load of $80 \mathrm{~W}$. The temperaiure distribution from $100^{\circ} \mathrm{F}$ ambient condition was used as input for the starting temperatures in the iy pothetical thermal accident (fire) calculation.

The damage from the free drop and puncture portions of the hypothetical accident wculd not adversely affect the performance of the container in the hypothetical thermal accident. Hence. the undamaged configuration was assumed.

\subsubsection{Thermal properiies of materials}

The thermal properties of materials used to compute the temperature distribution under steady state and transient conditions are listed in Table 5.1 (see Sect. 5.1.1).

\subsubsection{Thermal accident analysis}

The computational model previously used and described in Sect. 5.1.2, representing half of the container, was also used for the thermal accident analysis. The HEATING-3 computer program was used to determine the temperature distribution in the container that would resuls from the prescribed 30-min thermal exposure; the material constants given in Table 5.1 were used as computer input. The steady-state temperature distribution computed for the heat condition of normal transport $\left(100^{\circ} \mathrm{F}\right.$ ambient shade) was assumed to be the starting point. and $80 . W$ internal heat generation was included in the transient analysis.

\subsubsection{Container temperatures}

Cask temperatures were followed for $3 \mathrm{hr}$ after the conclusion of the fire. since regulations specify that the cask cannot be artificially cooled prior to this time unless the temperature in the center of the cask has begun to fall. 
The stainless steel uranum-shielded cask is an excellent onductor of he st with few air gaps to act as insulation. The cask heats and cools quickly. The neoprene gaskets on the closure plug ind the $\mathrm{O}$-ring, on the inner-cavity drain plug will be jestroyed in the hypothetical therma! accident. The temperature of the inner containes (see Fig. 6.6) reaches a maximum of $741^{\circ} \mathrm{F}$ at $96 \mathrm{~min}$ after the start of the test. or $66 \mathrm{~min}$ after the end of the "fire."

Temperatures of that magnitude will cause no damage to the inner container or to the solid contents. Consequently. if the cask is subjected to the high-temperature thermal environment. it is capable of withstanding it with no loss of contents and. therefore. meets thi: part of the regulations.

\section{t.4 Water Immersion}

The fourth in the sequence of hypothetical accident conditions to which the cask must be subjected is immersion in water in such a minner that all portions of the package are under at least 3 it of water for a period of not less than $8 \mathrm{hr}$.

It is assumed that the external gaskets of the cask will have been destroyed in the fire. The gaskets for the inner container will not, however. have been destroyed, and the integrity of these containers after the 30-ft free drop and fire test should be inviolate. The moderation afforded by the water is not detrimental (:ee Sect. \$) and provisions are available in the cask so that any water insise the cavity may be drained.

\section{CONTAINMENT}

The radivactive materials shipped in the OR.VI. Shipping Cask D-38 are solids contained inside an inne: container. The test and evaluation of the inner containers are described in Sect. 8.

"Special Form" material and material in "Spectal form Containment" may be shipped in th: OR.WI. Shipping Cask. Each "Special Form" material and container must. however. be yualified before usage.

\subsection{Conta:nment Requirements for Normal Conditions of Transport}

The inner containers are designed to withstand pressures and temperatures in excess of those encounteicd in sormal transport. To release of radinactive material. loss of coolant (air). or contamination of coolant should occur.

\subsection{Containment Requirement During the Hypothetical Accident}

The inner containers are designed to withstand fressures and temperatures in excess of those encountered in the hypothetical accident. 


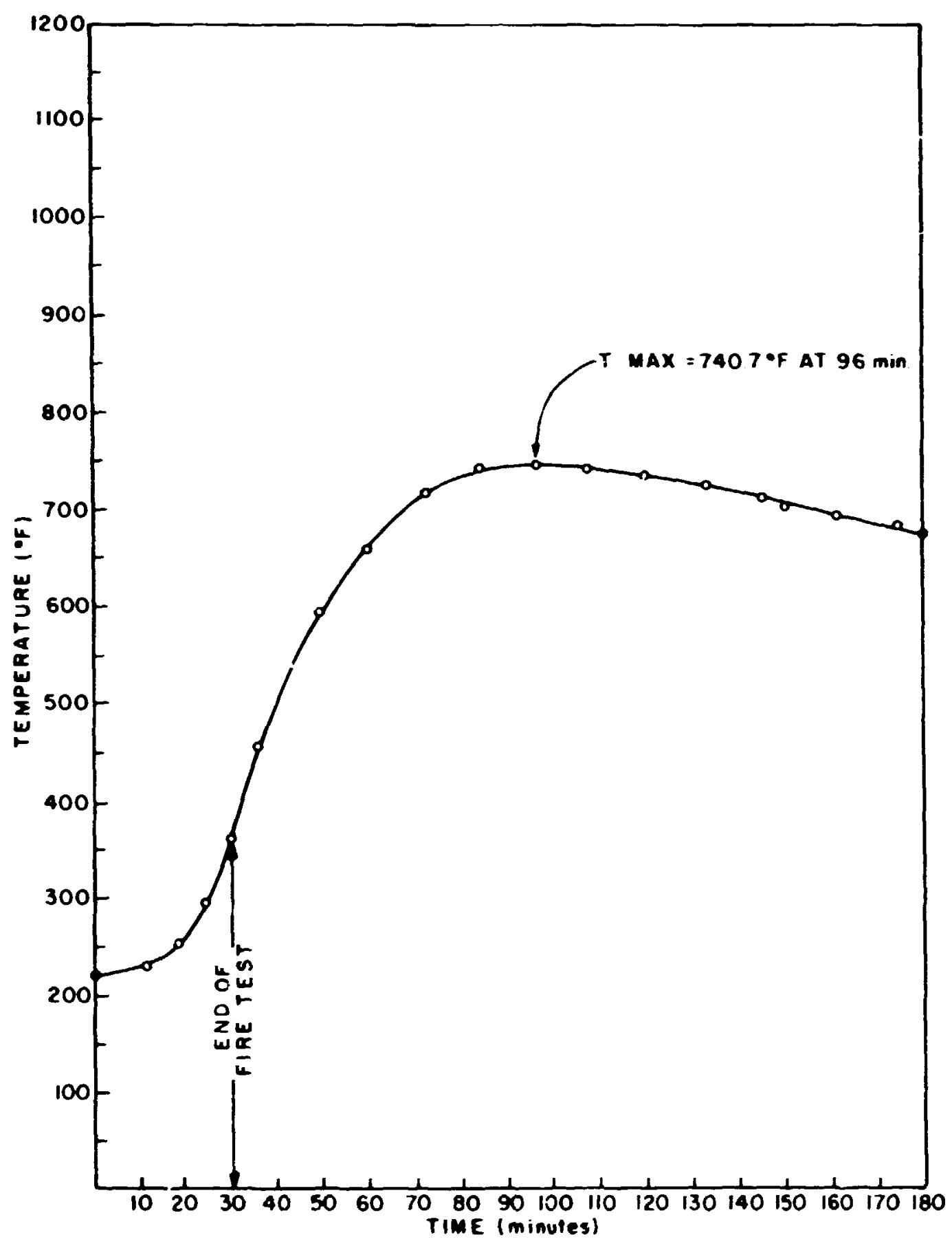

Fig. 6.6 Time vs temperature plot for inner-container seals as deteruined by HEATING-3 analysis of ORNL Shipping Cask D-38. 


\section{INIER CONTAINERS}

A spec $2 \mathrm{R}$ inner container has been developed, approved by $O R O$ and tested for use with the ORNL Shipping Cask D-38. Welded inner containers may also be used.

Fabrication of these weldei containers will be in accordance, with ORNL Quality Assurance Procedures for Quality Level III fabrication. Applicable approved OR.IL procedures will be used for welding. All welds will be appropriately inspected in accordance with approved OR.NL weld inspection procedures. Containers shall be leak tested using buhble techniques or helium leak-deiection methods.

\subsection{Inner Container}

The spec $2 \mathrm{R}$ contziner is shown in Fig. 8. I. The inner container needs to be only long enough to contain the material inside it.

The nature of the radioactive conients of the itrner container in the cask are specified as soiids. The inner container pressure that will develop due to the expansion of the contained gas will be assumed to be "the most severe anticipated case." With a maximum 80-W container loading. a pressure equivalent to the temperature of $741^{\circ} \mathrm{F}$ would be developed (see Fig. 6.6). The pressure is calculated as follows:

$$
P_{F}=T_{F} P_{s} T_{s}=(1201 \times 14.7) 530=33.3 \mathrm{psia} \text { (18.6 psig) }
$$

where

$$
\begin{aligned}
& P_{F}=\text { inner container pressure at } 741^{\circ} \mathrm{F} \text {. } \\
& \left.T_{F}=\text { maximum inner container temperature after fire. } 741^{\circ} \mathrm{F}+460\right)^{\circ} \text {. } \\
& P_{s}=\text { starti.ng inner container pressure. } 14.7 \mathrm{psia} . \\
& T_{s}=\text { starting inner container temperature. } 70^{\circ} \mathrm{F}+460^{\circ} .
\end{aligned}
$$

Acceptability will be demonstrated by showing that the welded inner container meets the reyuiremen:s of Sict. VIll of the ASME Boiler and Pressure Vessel Code. ${ }^{\text {ic }}$

\subsection{Inner container wall thickness}

From Paragraph LG-27.6 the minimum wall thickness for the cylindrical portion of the inner container is determined by

$$
t=\operatorname{Pr} \text { SE - 0.6P. }
$$


ORNL DWG 74-5540R3

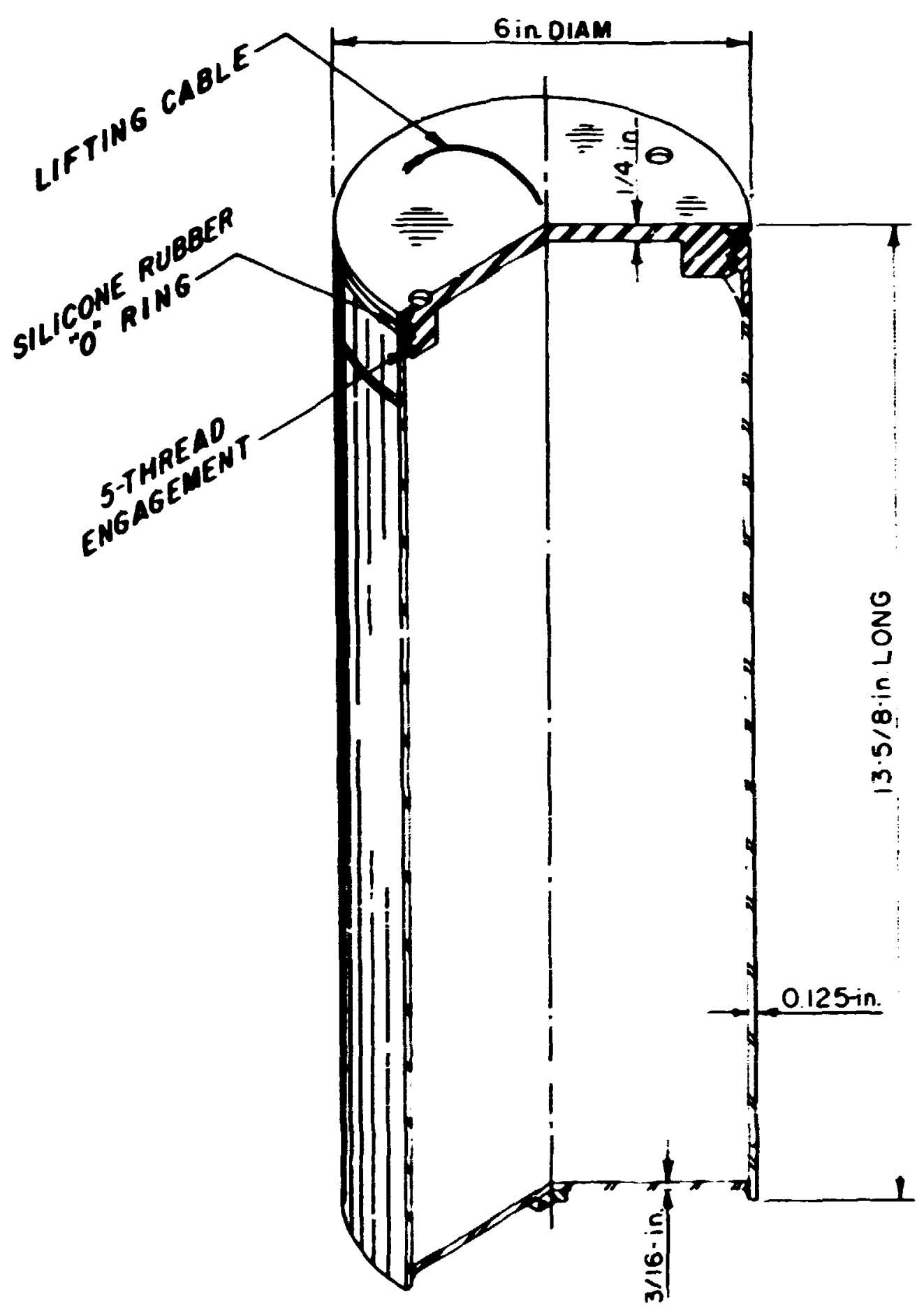

Fig. 8.1 Screw-top inner container. 
where

$$
\begin{aligned}
& P=\text { pressure. }: 8.6 \text { psig. } \\
& r=\text { inside radius of shell. } 2.875 \text { in.. } \\
& S=\text { design stress. } 7800 \text { psi (Table }\left(\text { HA-23). }{ }^{10}\right. \\
& E=\text { joint efficiencr. } 1.0 .
\end{aligned}
$$

The minirasm allowable wall thickness

$$
1=(18.6 \times 2.875) 7800(1.0)-9.6(18.6)=0.007 \text { in } .
$$

The wall thickness of the cylindrical portion of the serew top inner container is 0.125 in, which exceeds the requirements of the ASME Code.

\section{\$.1.2 Inner conlauner holtom-flat-head thickness}

From Paragraph LG-34." the minimum thickness of the bottom that head of the inner container is determined by

$$
i=\mathbf{d}(\mathbf{C P}) \mathrm{Si})^{:}
$$

whic

$$
\begin{aligned}
& d=\text { diameter inside. } 5.75 \text { in. } \\
& C=\text { desigri constant. } 0.3 \mathrm{in.} . \\
& P=\text { pressure. } 18.6 \text { psig. } \\
& S=\text { design stress. } 7800 \text { psi (sce Table }(H A-23) \text {, } \\
& t=5.75[0.3(18.6) 7800]^{12}=0.154 \text { in. }
\end{aligned}
$$

The bottom flat head of the screw top inner container is 3 16-in. thick and meets the requirements of the ASME Code. 


\subsubsection{Inner cor:tainer wipthead tlickness}

From Pargraph 1G-34." the minimum thickness of the screw tof head of the inner container is deterrmined by

$$
t=\operatorname{drCP} S)^{:}:
$$

where

$$
\begin{aligned}
& d=\text { dameter insix.e. } 5.75 \text { in. } \\
& C=\text { design cons ant. } 0.75 \\
& P=\text { pressure. } 18.6 \text { psig. } \\
& S=\text { design } 2 \text { ress. } 7800 \text { psi }\left(\text { sec Table }(\text { HA }-23)^{40}\right. \\
& t=5.75\left[(0.75 \times[8.6) 7800]^{i 2}=0.243 .\right.
\end{aligned}
$$

The screw top head of the screw top inner container is 14 in. thick ind exceeds the requirements of the ASME Code.

\subsection{Special form and Special Form Containers}

Malerial may be silipped in this eask as Special form- material or in -Special form Containers." When this type of shipment is contemplated. the "Special Form" material or container must the qualified by specially designated OR.NI. personnel who ean certify this type of shipment.

\section{CRITICAIITY}

The analysis for the single cask given below is adequate for an infinite array of similar containers. 


\subsection{Evaluation of a Single Package}

A criticality analysus has been made isec Nucleat Saiet: Revien - $5 x$ in Appendix 12:21.

Since the yuanitis of fissik isotopes carried is below all minimum crikal masses for inese sotopes under optimum moderation and reflection. and the eask effectineiy isolato tine contents fre- net!ron interaction with packages of simibr design. unlimited numbers could be stacked with no criticalits protiem occurring. Ihus. the package is adequmie for Fissike (lass I Shipments

\section{SHIELDING EVALXAIION}

10.1 Discussion and Results

The cavity in the ORNL. Shipping (ask D-3\$ is surrounded by a 9.28-in-thick staintess steel inner shel! and a 0.41 -in-thick outer stainless steel stiell. Ine shiciding cavit: between the two is filled with depieted uranum that is $2-34$-in. thick. In addition. the cask contents are limited to 2 source strength that will not exceed the allowable radiation dose limits of the DOT regulations.'

The shielding effectiveness will not the reduces by the conditwons of notmal transport or by the hypothetical accident.

\section{QI AI.ITY ASSTRANCE}

I! I Fabrication. Irspection. and Acceptance Iests

This container was fabricated in the ORNI and Y-12 Machine Shops in accordance with normal shop fabrication procedures. Material was specified on the original drauings as $\mathbf{- 3 0 0}$ Series SST. Material was withdraun from Stores stock. The cask was inspected by OR.II. Shop Inspection personnel for conformance to the drawitigs. quality of isorkmanship. and compliance with welding requirements when fabricated. In the opinion of the inspecting personnel. the weidments were made in accordance with the drawings and specifications. This is further supponed by the fact that the casks have operated for 6 years without failures or loss of effectiveness. An inspection of the cask was made in verify its integrity (sec Appendix 12.5). The routine operating inspection pincedures specify periodic weld inspections to verify weld iritegrity. 


\subsection{Operating Procedures and Routuze Inspections}

Ithe Chemseal Iechnolog! Inswon has extabisht operating and routune inspection procedures and siandard checklists to ensure that all shipments are sife and that they comply with NRC rezulatiress. as well as all ORNL procedures and regubtions. A copy of typici procedures and checklists are presented in Appendix 126. Ihe completed records are kept in Błdg- 4500. Room A-16.

\subsection{Periodic Mamtenance and Inspections}

Shipments will be inspected biennis!l! and before each shipmen! is made. as outlined :n Appendix 12.h. Maintenance will be performed when inspectirns indicate damage. Ihe completed records ate kept in Bldg. 4500X. Roum t-it. 
12. IPPENIDIXS 


\subsection{Appendix A: Drawings}

ORNL Shipping Cask D-38 Assembly and Details 
BLANK PAGE 


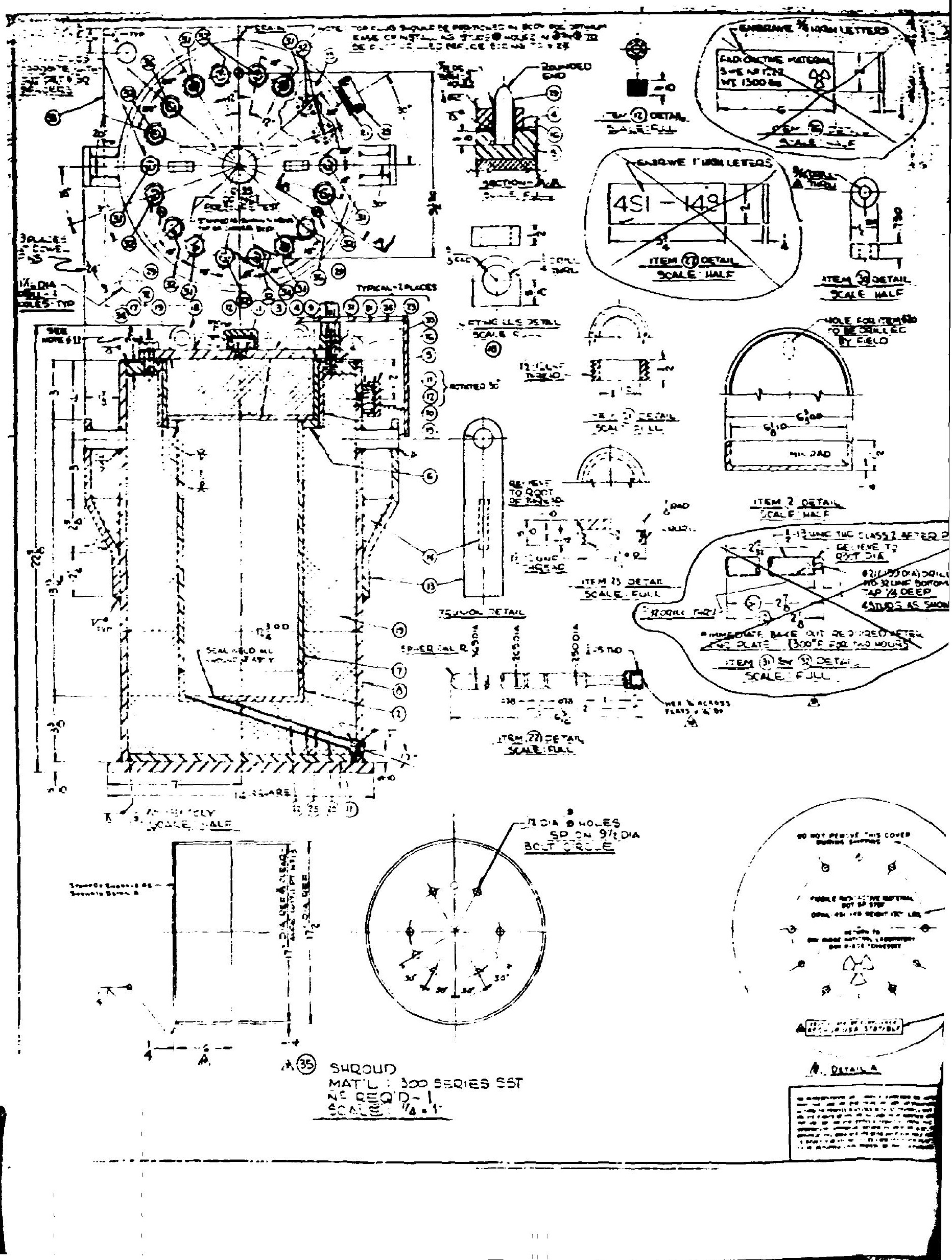


BLANK PAGE

\% 


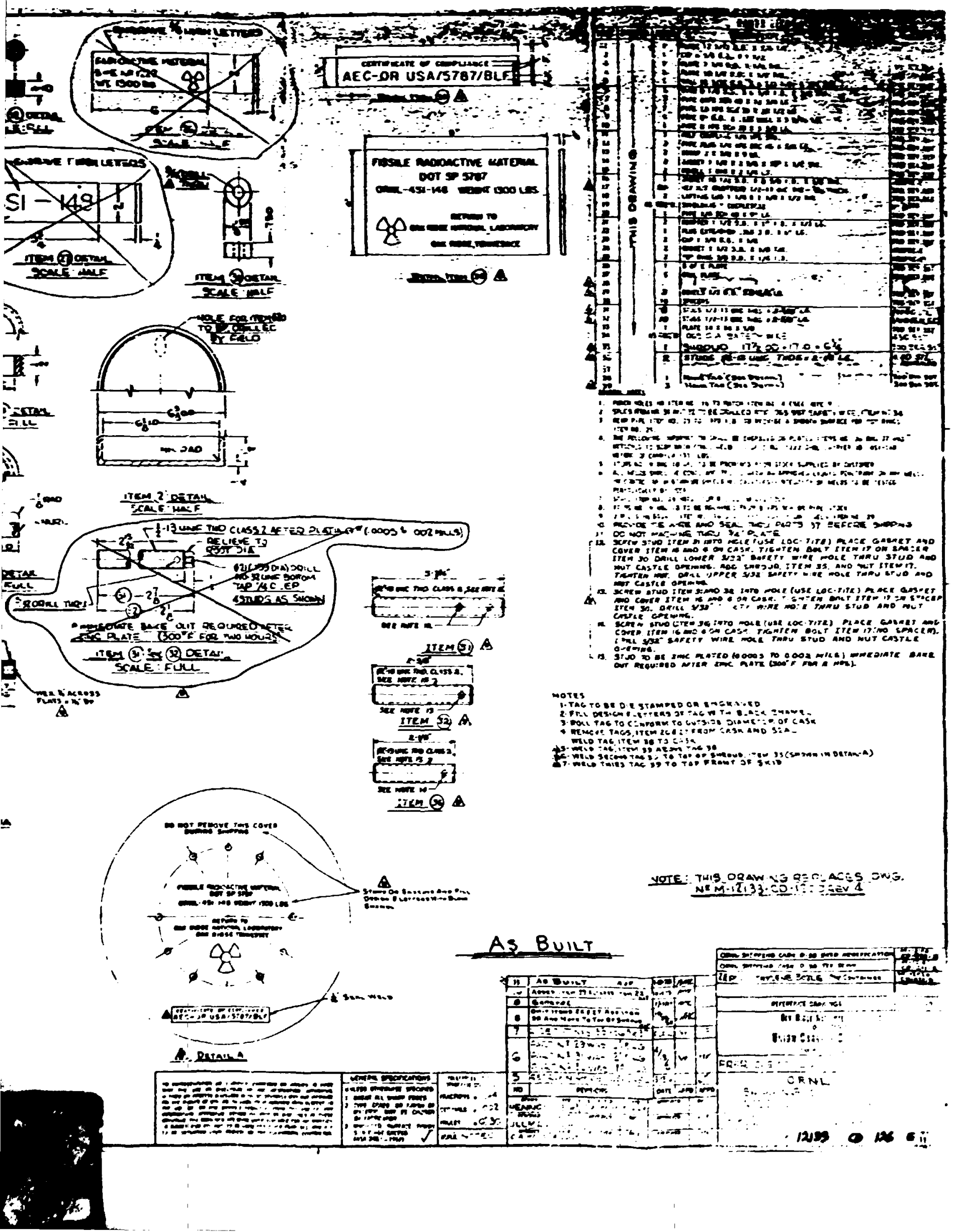




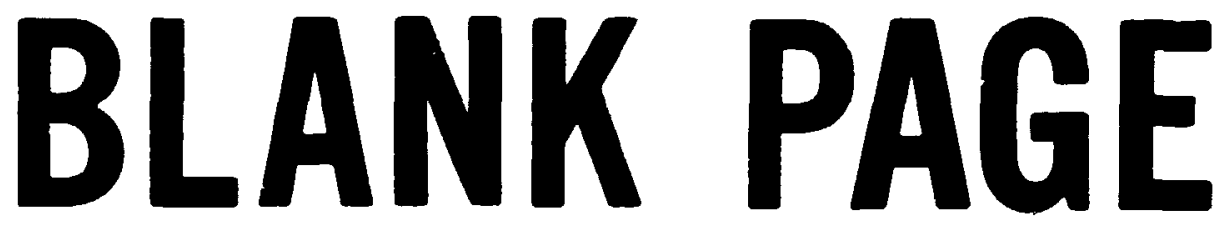




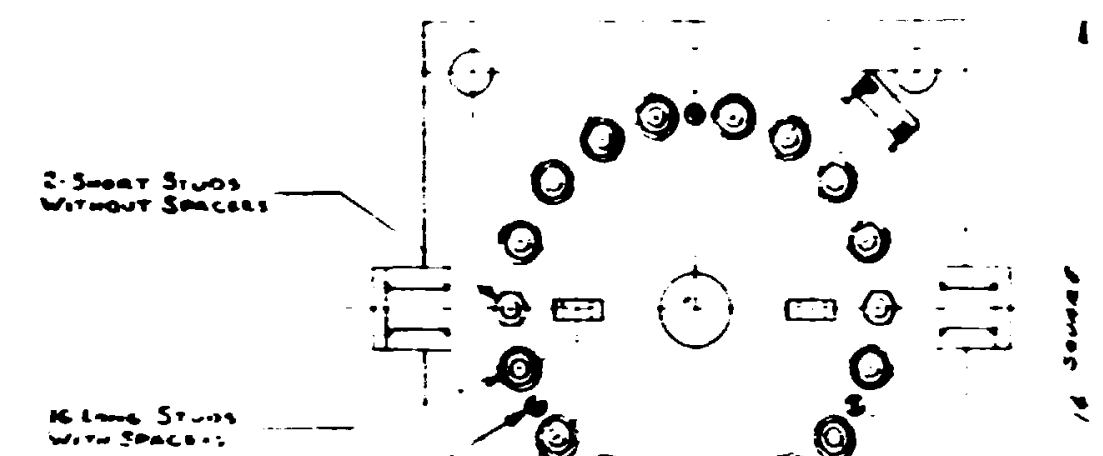

21.0loca-ncm -

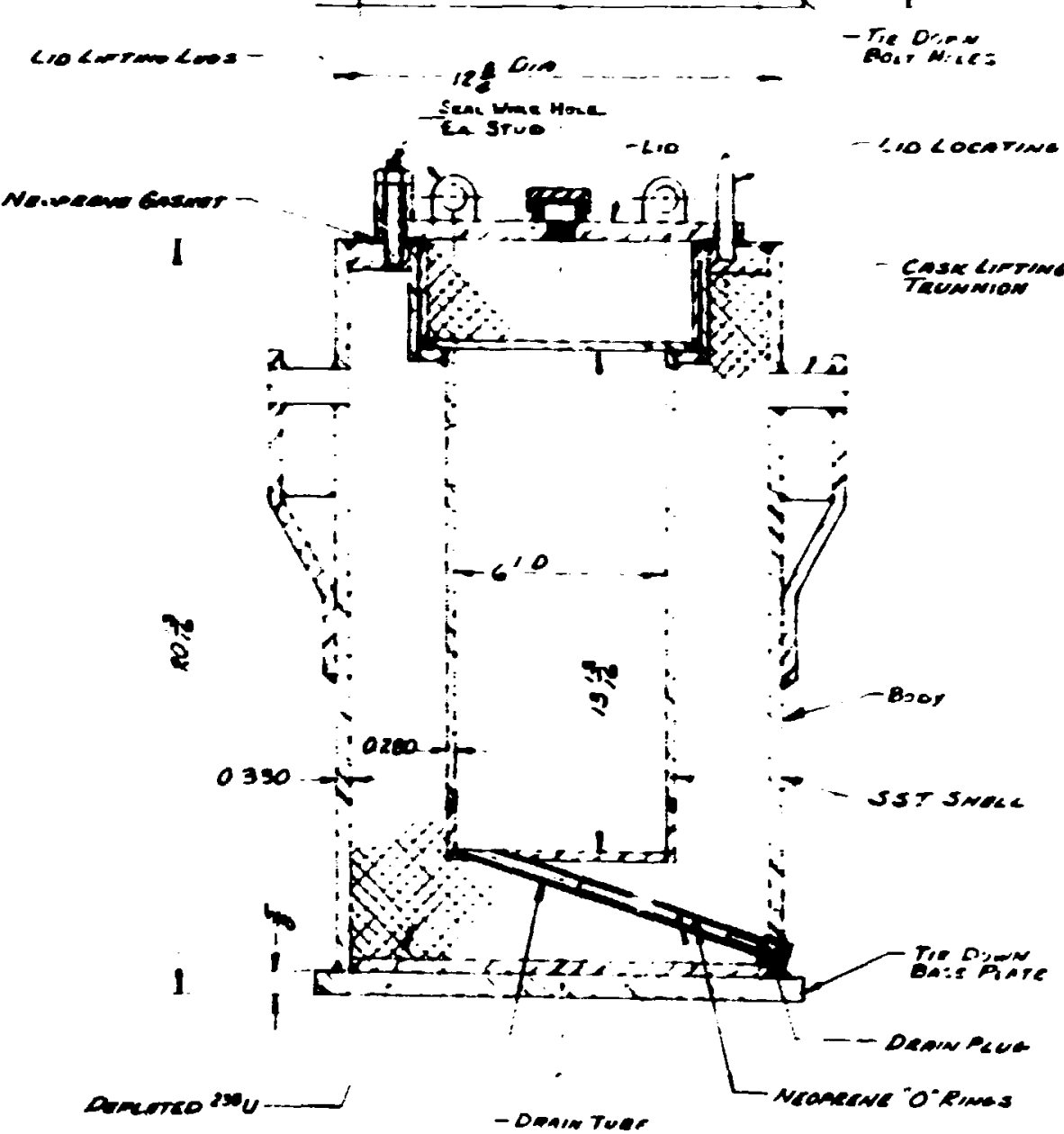

URANium Smilloed Cass.

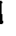

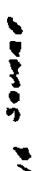

2

$-\mathrm{O}-\cdots$
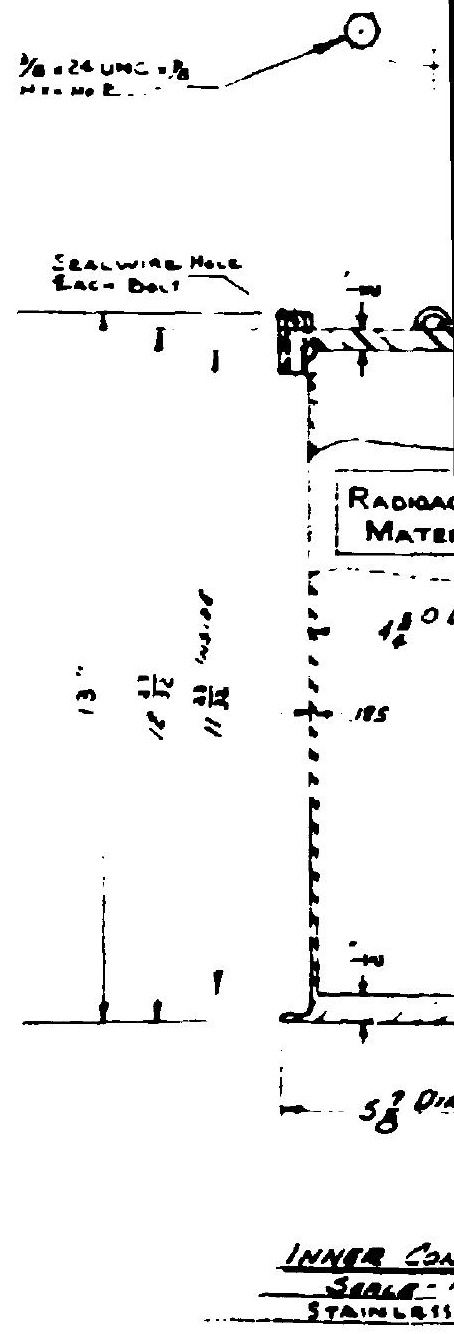

$-7=2$

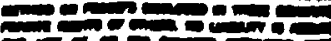

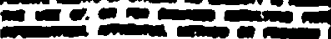

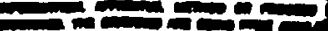

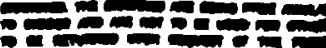




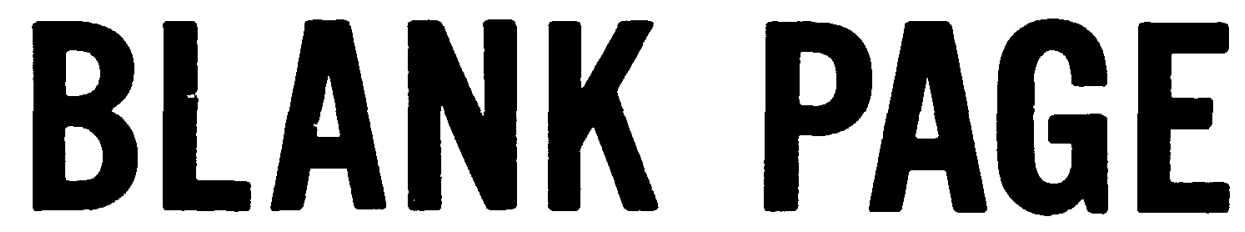




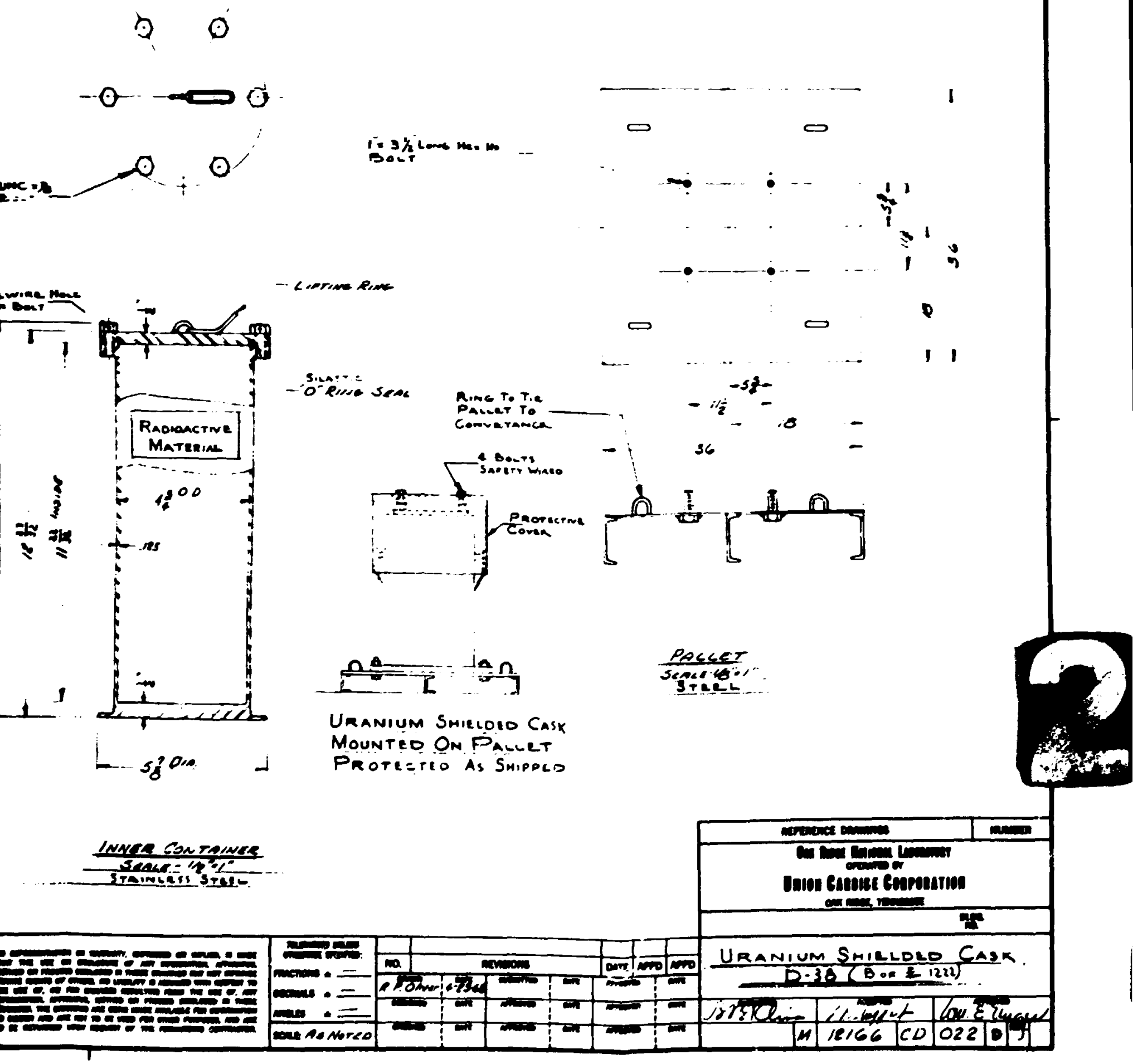




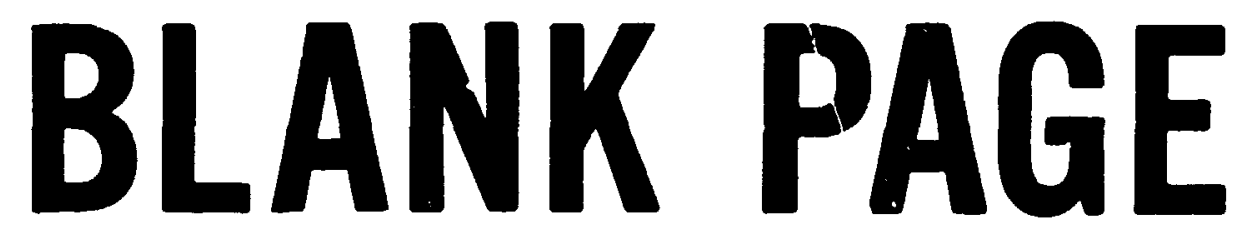




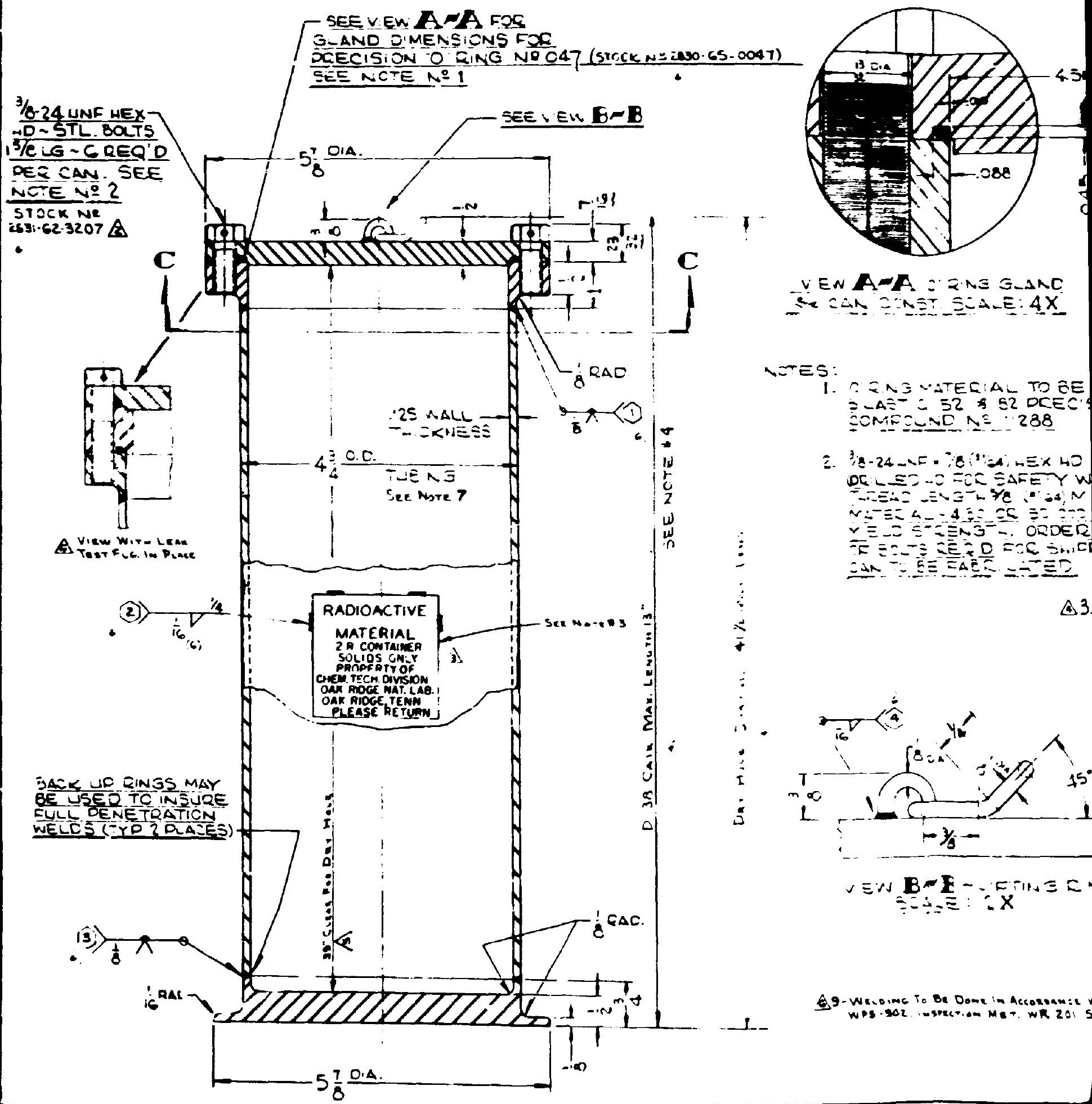


BLANK PAGE 


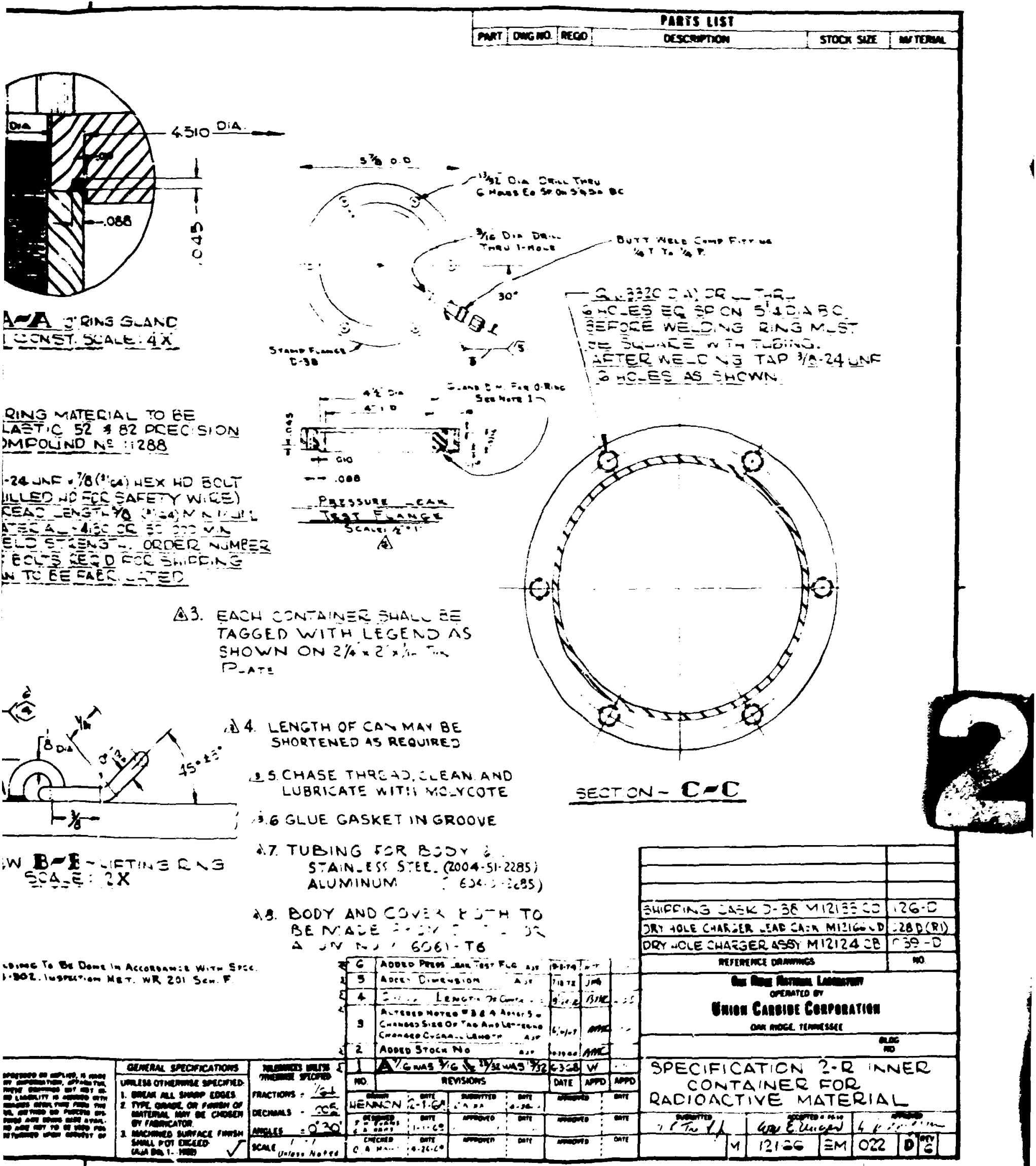




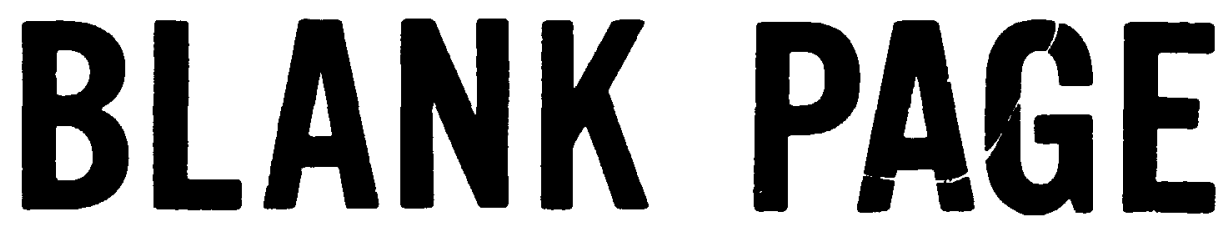


12.2 Appendix B: Approval Documents

\author{
Second Revised Special Parmit No. 5787 \\ Third Revision Special Permit No. 5787 \\ Interim Certif fiate of Compliance \\ AEC OR USA $5787 /$ BLF \\ ORNL Critfcalfty Cormittee Nuclear \\ Safety Reyiew Request No. 777 \\ Letter ORNL Transportation Comittee \\ of Approval of Internal Review of \\ SARP
}

Date

Oct. 1, 1969

Page

Aug. 26, 1971

70

Sept. 21, 1973

75

May 23, 1975

76

Nov. 4,1977

78 
BLANK PAGE 


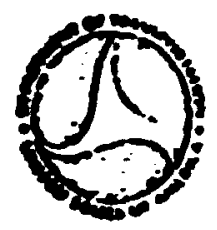

\author{
DEPRRTMENT OF TPANSPORTATION \\ HAZARDOUS MATERIALS REGULATIONS BOARD \\ wasminctom, O.C. zesp
}

EECOND REVISED SPECIAL PERMIT NO. 5787 (COMPLETE REVISION)

This special permit is revised pursuant to $46 \mathrm{CFR} 146.02-25$ of the U. S. Coast Cuard (USCC) Dangerous Cargo Regulations and 49 CFR 170.15 of the Department of Transportation (DOT) Bazardous Materials Regulations, as amended, and on the basis of the August 19, 1969, petition by the Oak Ridge National Laboratory and their original petition datec Septeaber 17, 1968.

1. Shipaents of fissl le and large quantities of ridloactive naterlals, n.o.s., are hereby authorlzed in the paciraging as described in this special permit. This packaging, when constructed and assembled as prescribed herein, with the contents as authorized herein meets the standards prescribed in the DOr regulations, Sections $173.395(c)(2), 173.396(c)(3)$, and $173.398(\mathrm{c})$. Shipinents must be in accordance with the provisions of the U. S. Atomic Energy Comsission (USAEC), Oak Rdge Operations Office approval dated August 29, 1968, and as further provided for herein.

2. Each shipper, under this permit, other than the pet1tioner nared above, and the other previously identified pet1tioner: USAEC, Oak Ridge, Tennessee, shall register his Identity with this Board prior to his first shipment, and shall have a copy of this permit in his possession before making any shipment.

3. The packaging authorized by this perate consists of a etainless-steel clad, deplcted uranium-shielded cask, which Is a right cylinder, $123 / 4^{\prime \prime}$ O.D. by $225 / 8^{\prime \prime}$ high with a 6" dianeter by $1313 / 16^{\prime \prime}$ decp central cavity. The uranium chielding thickness is $23 / 4^{n}$. Cask closure is by means of a plug-type uranium-shielded top 11d, with bolted, gasketed closure. The cask weight is about 1300 pounds. Contcnts must be loaded within DOT Specification $2 R$ or equivalent, primary inner cuntainment, with liquids to be additionaliy contained in polyethylene or stainless steel bottles. The package is Identified as the Model No. D-38 Uraniun Shielded Shipping Cask, and is described on Oak Pidge National Laboracory's drawing numbers $M-12166-C D-022-D$ and $68-4126$. 
4. The contents of each package authorized by this perait cuasist of fissile and large quantities of radioactive material n.0.s., In the form of solld and liquid mixed fission products, fuel elements, or uaste products. The maximum theral decay energy of the contents shall nct exceed 80 watts and the cotal radioactivity shall not exceed 500 curies. The flselle radioactive material contents shall not exceed 500 greas of uranium-235, 350 grans of uranium-233 or plurenium239, or 350 grams of any combination thereof.

5. The authorized packaging meets the requirements for shipwent as Fissile Class I. The transport index must be assigned based on external radiation levels.

6. The authorized package dascribed herein is hereby cert1fied as meeting the specific requirements of the International Atomic Energy Agency's (IAEA) "Regulations for the Safe Transport of Radioactive Material". Safety Series No, 6, 1967 edition, as follows:

c. Marginal C-6.2.2 - The package design meets the requirements for Type B packaging for radiosctive aterials.

b., Marginal C-6.2.3 - The package design meets the requirements for Type B packaging for large quantity (source) radloactive materials. Specifically, the packaging design meets the requirements of Marginal C-6.2.3.1(a) for unilateral approval.

c. Marginal C-6.2.4 - The package design weets the requirements for Fissile Class I shipments.

8. Marginal C-2.4.3 - The packaging design is based on the ambient conditions.

2. Marglnal C-6.5 - No special transport ontrols are necessary during carriage and no special arrangeents have been prescribed, except as specified hereln.

7. The outside of each package must be plainly and durably arked "USA DOT SP 5787" and "TYPE B", In connection wth and In addieion to the cther markings and labels prescribed by the Dor regulations. Each shipping paper issued in connection with ehlpac: :s made ur.der chis permit must bear the notation "DOT SPECIAL PEKIIT NO. 5787", in connection with the comodity description thercun. 
8. Each package must have its gross welght plainly and durably marked on the outside of the package.

9. This pernit authorizes shipments only by vessel and notor rebicle.

10. For shipoents by water:

a. A copy of this pernit must be carried aboard any vessel transporting radioactive material under these terms.

b. The shipper or agent stiall notify the USCG Captain of the Port in the port area through which the shipment is to be made, of the name of the vessel on which the shipment is to be made, and of the time, date, and place of loading or unloading. Then the initial notification is given in a port area, it must be accompanied by a copy of this permit, addressed to the attention of that Captain of the Port.

c. Packages shall not be overstowed with any other cargo. If stowed below decks, the hold or compartwent in which stowed mist be ventilated.

11. The shipper is required to furnish an experience report to this Board before expiration of the permit and when any amendment is requested. This report must Include the approximate number of packages shipped, and the number of packages involved In any loss of contents. The modes of transportation used for these shipments must al so be shown.

i2. Erior to each shipment authorized by this permit, the ohipper shall notify the consignee and, for export shipments, the competent authority of any country into or through which the package will pass, of the dates of shipment and expected arrival. The shipper shall notify each consignee of any special loading/unloading instructions prior to his first shipment,

13. Any Incident Involving loss of contents of the package must be reported sa this Board at the carliest fcasible moment followIng the incident. 
14. This permit does not relieve the shipper or carrier from compliance with any requirement of either the DOT regulations, Including 46 CFR Parts 146 to 149 of the USCG Regulations, except as specifically provided for herein, or the regulations of any foreign goverment into or through which the package wll be carried.

15. . This permit expires September 30,1971 , and may be revoked for cause at any time.

Iesued at Washington, D.C.:

E. G. Grundy:-Capt

For the Commandant

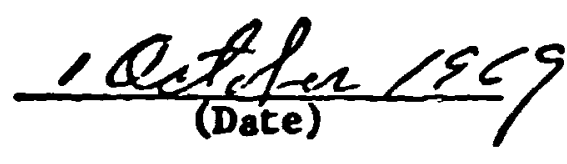

J. S. Coast Guard
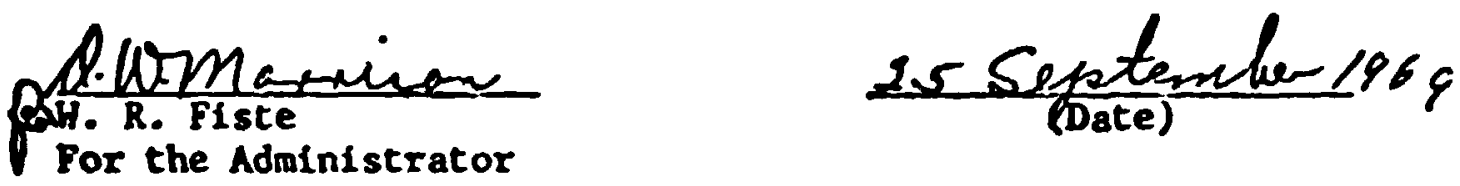

Pederal Highway Administration

Address all Inquirles to: Secretary, Hazardous Materlals Regulations Board, U.S. Department of Transportation, Washington, D.C. 20590. Attention: Special Permits.

D1st: $a, b, d, h, 1$

USAIC, Oak Ridge, Tennessee/ 


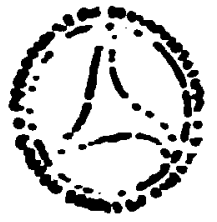

\author{
DEPARTMENT OF TI:ANEPORTATION \\ Hazanosur: matckili ls mi'Gla atioxe mann \\ cacuenorom of aso
}

EPrcial Pestrt so. 5787

TILES REVISIO:

Turscant to 46 CFR 146.02-25 of the U.s. Cosst Cuard (USC6) Dingrtons Cargo Reeulatioas and 49 CFR 270.15 of the Departaint of Transportation (Dor) Hazardous Hi:cerials Refulations, as ascuded, and on the basis of che July 22, 1971, petition by the Oak Ridze Pational Laboratory, Oat: Ridge, Tenossee:

Epecial Perpll do. 5787 is hereby aneaded by revising paragraph (15) to read as follers:

"15. This perodt expltes on Septeaber 30, 1973."

Al other terms of this perait, as revised, reanin unchunged. The cooplete permit currently in effect consists of the sccood and inird Revisions.

Issegd at Washington, D.C.:

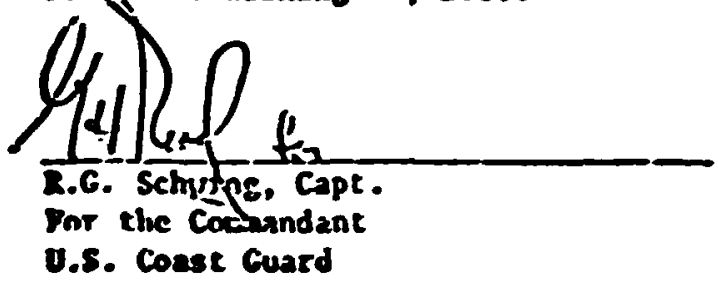

21 R!E :iัi

R.G. Schutpe, Capt.

(DATE)

v.s. Coase cuard
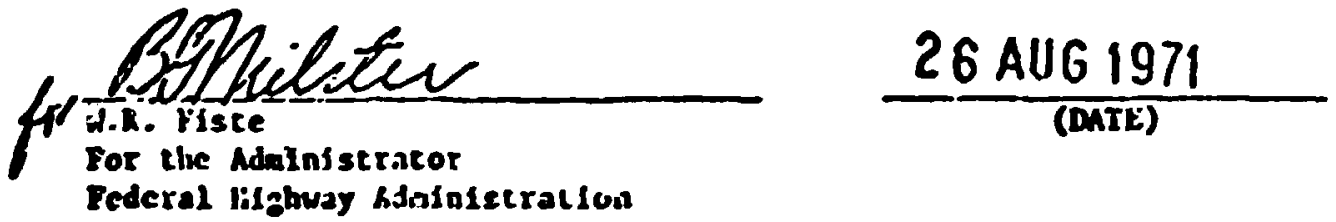

Addrese all Innulrics to: Sccretary, llaxardous theterfals Rezulations Dosrd, U.S. Departesnt of Trineportation, Kashinetoil, D.C. 20590. Alcention: Special Perales.

Dist: $a, b, d, h, 1$ 


\begin{tabular}{|c|c|c|c|c|c|}
\hline \multicolumn{6}{|c|}{ 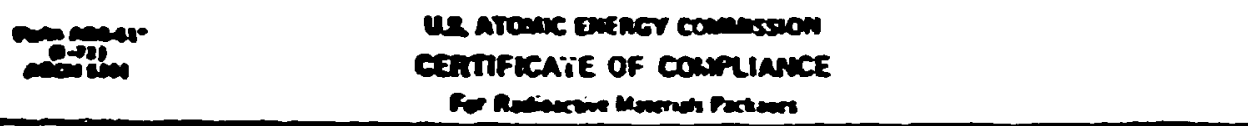 } \\
\hline atec on & usa & $5787 / 405$ & the & kepolas & 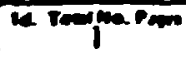 \\
\hline
\end{tabular}

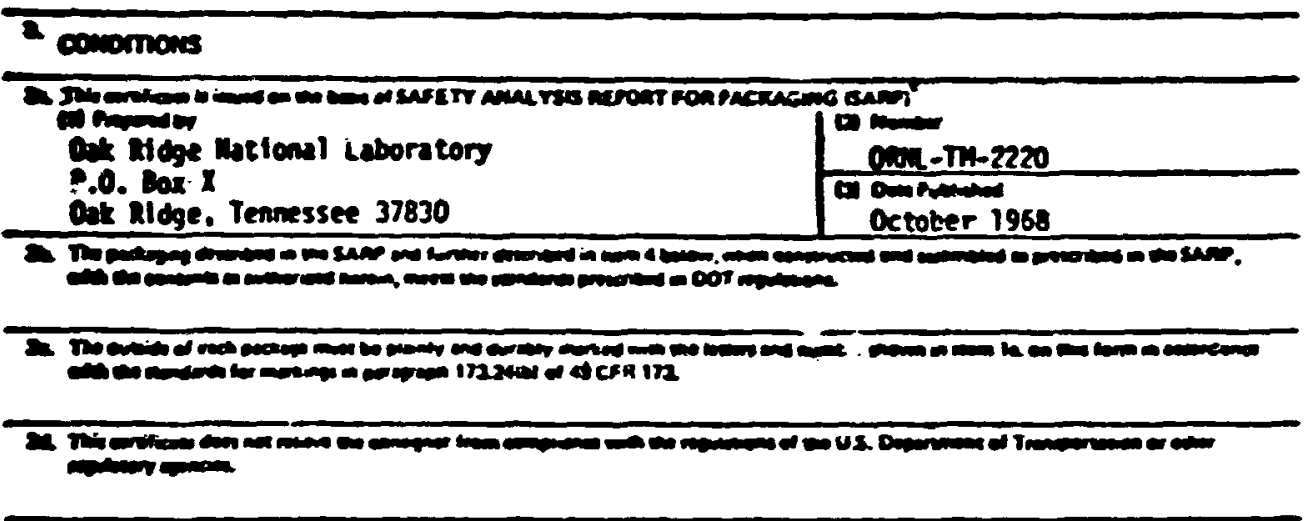

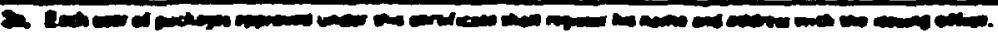

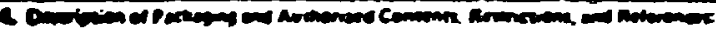

A. The prekaging consists of a stairitess-stea) clad, depleted (0.2 wt: 23su) uranice shielded cask, wich is a right circular cyisnmer, 12-3/4- 0.0. $\times 22-5 / 8^{\circ}$ htgh r.: th 6* 1.a. $x$ ij-13/1j" ceep central cavity. The uranium shield is $2-3 / 4^{\circ}$ thica. Cast closure is by mears of alug-tyce uranicm-shieldad tos ifd, which is bo!ted and seled with two meoorene $00^{\circ}$-rings. Contents mast be loeded within a cot sperificatoa 2R or equivaient, priasy inner containsent. with liquids to be additionilig contained in polyathylene or stainless bottles. The gross weight of the package is chewt $1300 \mathrm{lb}$.

B. The authorized contents of each package consist of fissile and large quantities of radiactive aterial $11.0 . S$. In the form of solid and liquld alxed fission prociucs, fal elements, or waste products. The aximan tnermal decay energy of the sontenis finil me exceed 20 watts and the total radioactivity shall not excsed 500 cur :es. The fisstle radiosctive material contents shal: wot exceed $500 \mathrm{~g}$ of $235 \mathrm{U}, 350 \mathrm{~g}$ of 2314 or $235 \mathrm{Pu}$, or $350 \mathrm{~g}$ of any cosination.

C. Shipaents are authorized as Fissile Class I. The Transport Index is assigned on the basis of external rasiztion levels.

h. Shicentes are auteardias by vessel and resor vehicle.

\begin{tabular}{|c|c|c|}
\hline \multicolumn{3}{|c|}{ 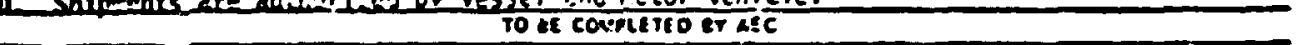 } \\
\hline \multirow{3}{*}{ 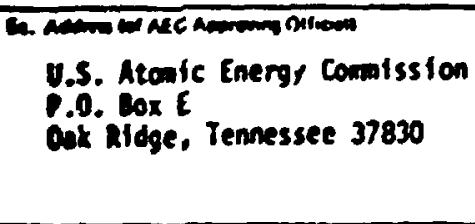 } & \multirow{2}{*}{\multicolumn{2}{|c|}{ 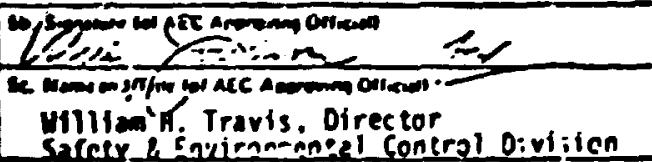 }} \\
\hline & & \\
\hline & 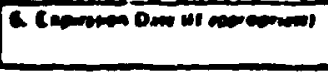 & $\begin{array}{l}\text { 1. Osw } \\
\text { Seprember } 21,19: 3\end{array}$ \\
\hline
\end{tabular}

\section{INTERIM}




\section{Reduest fOR nuclean SAFETY REVIEW}

This request coners operations with fissike motenai in a contro: area and or lissi:- materia!

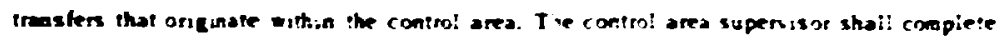
the bocts below and describe the process and gi peraitims to be pertormed. emphasizint we provis cons for noclear criticaisy safety on the " verse side of this pace. This request all be epproved by the Radistion Control Oficers the originatine Division and the

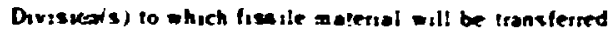

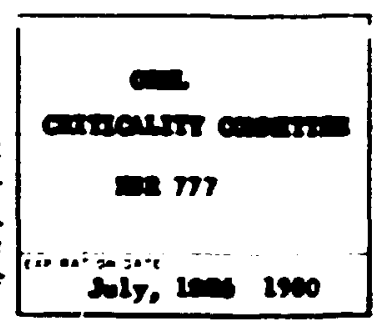

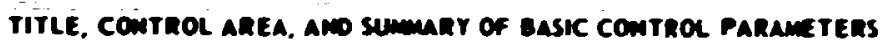

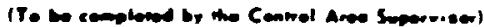

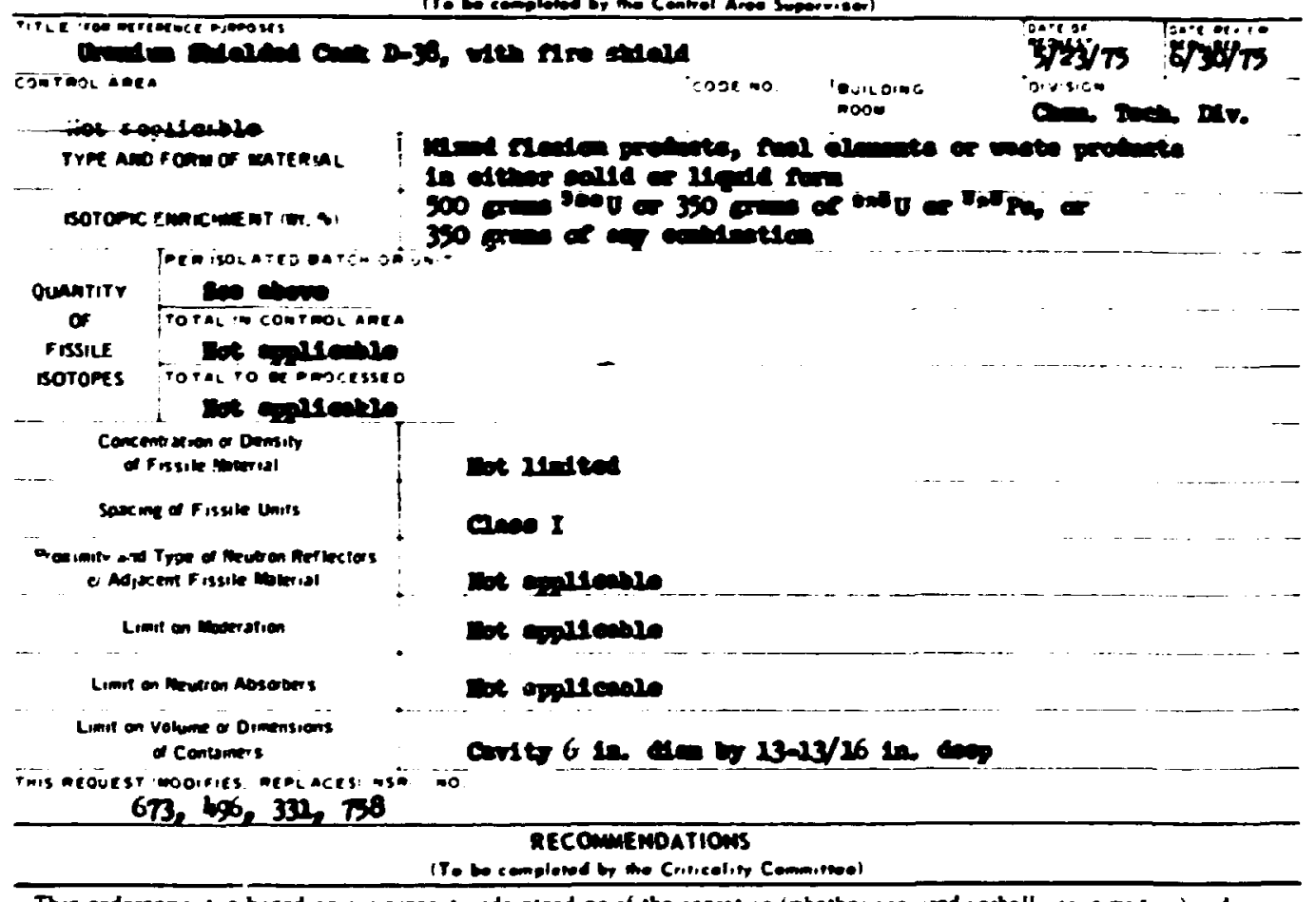

This endorsement is based on nut present undersianding of the operation (abe thet acquired verbell, of in writing) and is subject to review and canceliation.

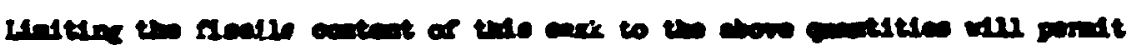

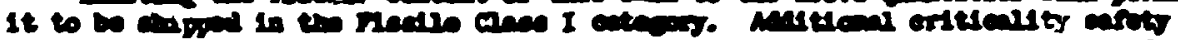

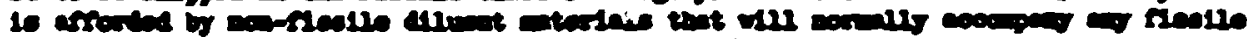

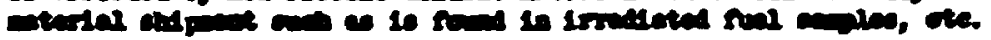

uci.39:" 


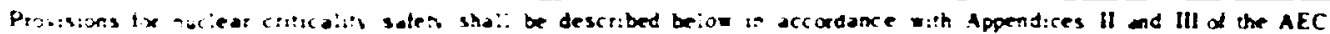

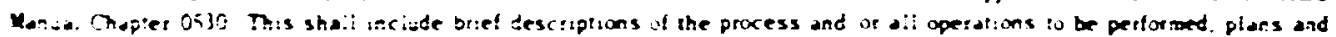

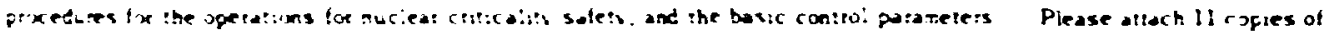
ieterenced cravines onc Jocuxamis

\footnotetext{
A Alv

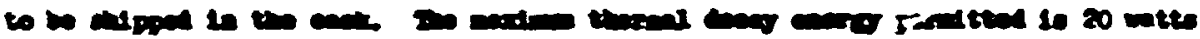
roe to lesedd atimate.
}

a. antersis onisus

ב211

Tionition sath

Itra 192

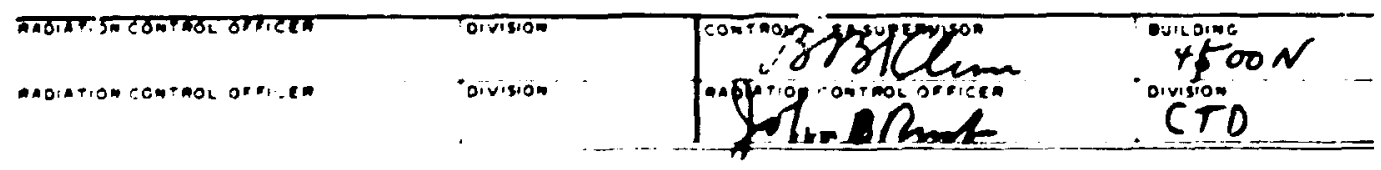




\section{INTRA.LABORATORY CORRESPONDENCE OAK RIDGE NATIONAL LABORATORY}

November 4, 1977

To:

R. D. Seagren

From:

Transportation Committee

Subject.: SARP - ORNL Shipping Cask D.38

The Committee has reviewed your Draft dated October 17, 1977, for the subject cask. The SARP is approved for technical content and approach in performing the analysis.

Attached are cumments $\mathrm{fmm}$ some individuals of the Committee for changes needed or suggested.

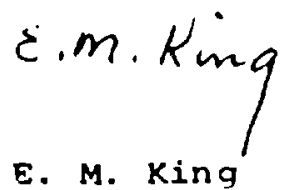

cc: Transportation Committee

H. G. Burger

J. A. Cox 


\section{Appendex (Compuler Progeam to Cakulat. \\ Corner-i)rup Negatise Acceleration Forces}

\section{Program 1001 Cask}

Derisation of Equations

When a cask constructed of single ideally plastic material impacts on its top corner, the major portion of th: kinetic energy will be dissipated through displacement of material in the impact area. An ideally plastic material is a material that has a constant stress for all values of stain

Ihe expression

$$
d i=s d
$$

where

$S=$ the quantity of energy required to displace a unit volume of material.

$V=$ the displaced volume of material and can be used as a basis for deiermining the effect of the top-corner impact. The lack of an accurate numerical value of $S$ necessitates a conservative estimation of its value.

With relerence to the computational diagram illustrated in Fig. 121 , it may be said that

$$
d V=J 2 X Y d Z
$$

B. trigonomitry.

$$
\begin{aligned}
& X=r(\cos B-\cos A) . \\
& Y=x \tan \alpha-\tan \alpha r(\cos B-\cos A) . \\
& d Z=r \cos d B .
\end{aligned}
$$

It follows that.

$$
d t=S X Y d Z 2
$$

and

$$
\mathrm{l}=\mathrm{IJl}=\mathrm{ISXYdZ2}
$$

This expression can be readily solved using the computer. The value for the angie A cat 

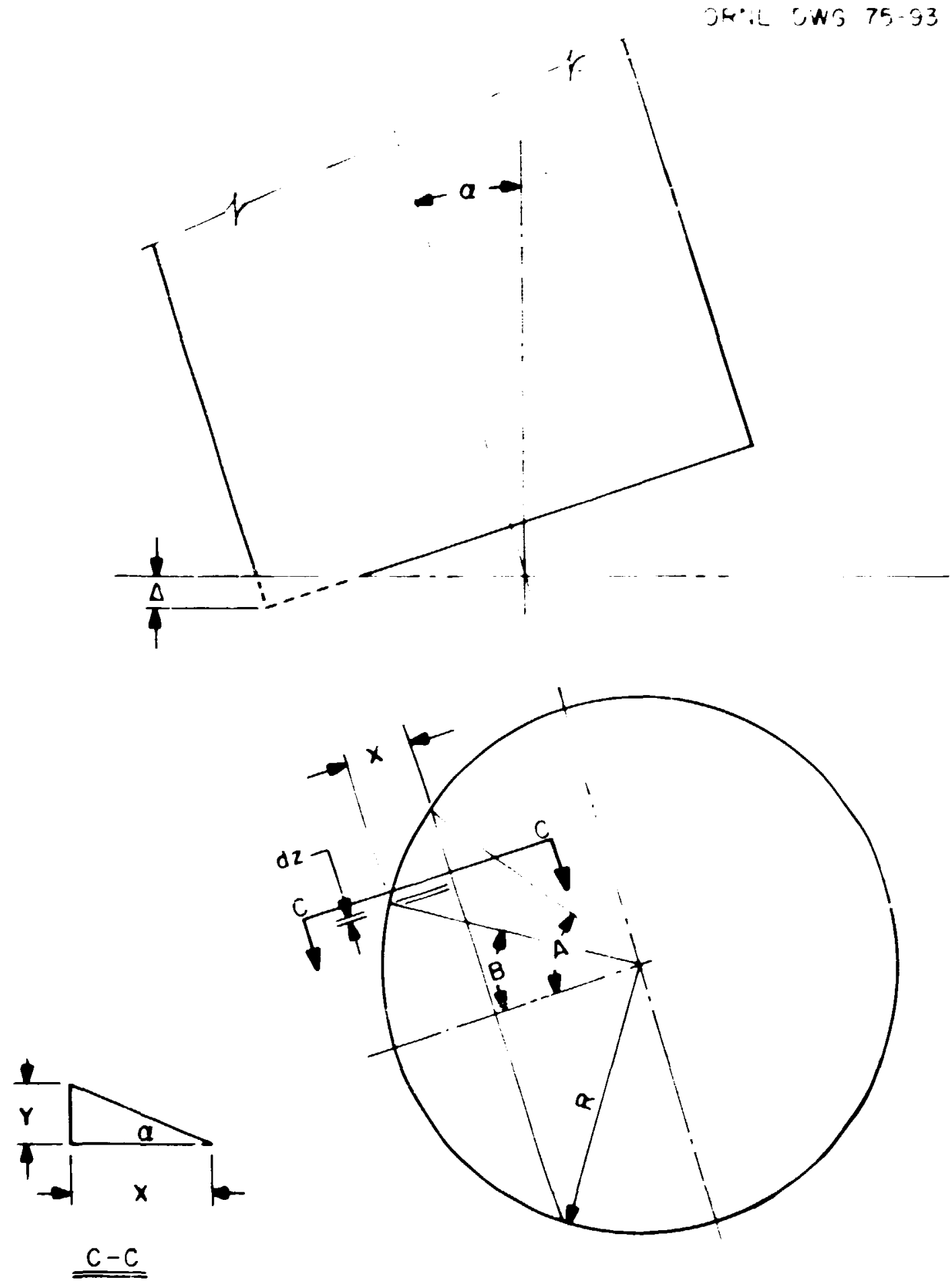

Fig. 12.1 Model for corner drop calculations. 
be assumed. and $B$ can he incremented trim - A to $A$ or trom 0 to $A$ it the result 1 multiplied b! 2 and the energ! required tor the ansumed detormation " computed i is siated imall incremented. and the energy required is comp..sed with the eask portental energy. In this manner a calculated impact histon is produced. The program alw computes other sariables using the expression: belou. The maximum deformation. $\therefore$.

$$
\therefore=\sin a(1-B 0, A)(r)
$$

$(12-x)$

The applied torce. $f . t=d t d$. and the acceleration. a. Was computed trom the cyuation

$$
=\mathbf{F} \mathbf{H}
$$

Itie veloclis at any incrementi a found from the kinetic energy principle

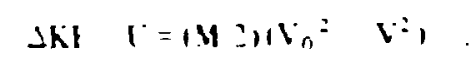

ir

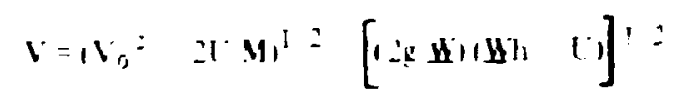

where

$$
\begin{aligned}
& \boldsymbol{v}_{0}=\text { initial velocity. } \\
& \mathbf{M}=\text { cask mass. } \\
& \underline{\mathbf{w}}=\text { weight. } \\
& \mathbf{h}=\text { drop height. } \\
& \boldsymbol{g}=\text { gravitational constant. }
\end{aligned}
$$

The tume is computed irom the relationship

$$
a=d v d
$$

or

$$
d \mathbf{t}=\mathbf{d} \mathbf{a}
$$

and summary techniques.

The computer pregram is given and the restits for specific energies of $1(10) .1000$ and 2600.000 in. !h in.' are given. The plots of the negative accelerations vs jeformi. ion are given in rigs. 12.2 and 12.3 . 


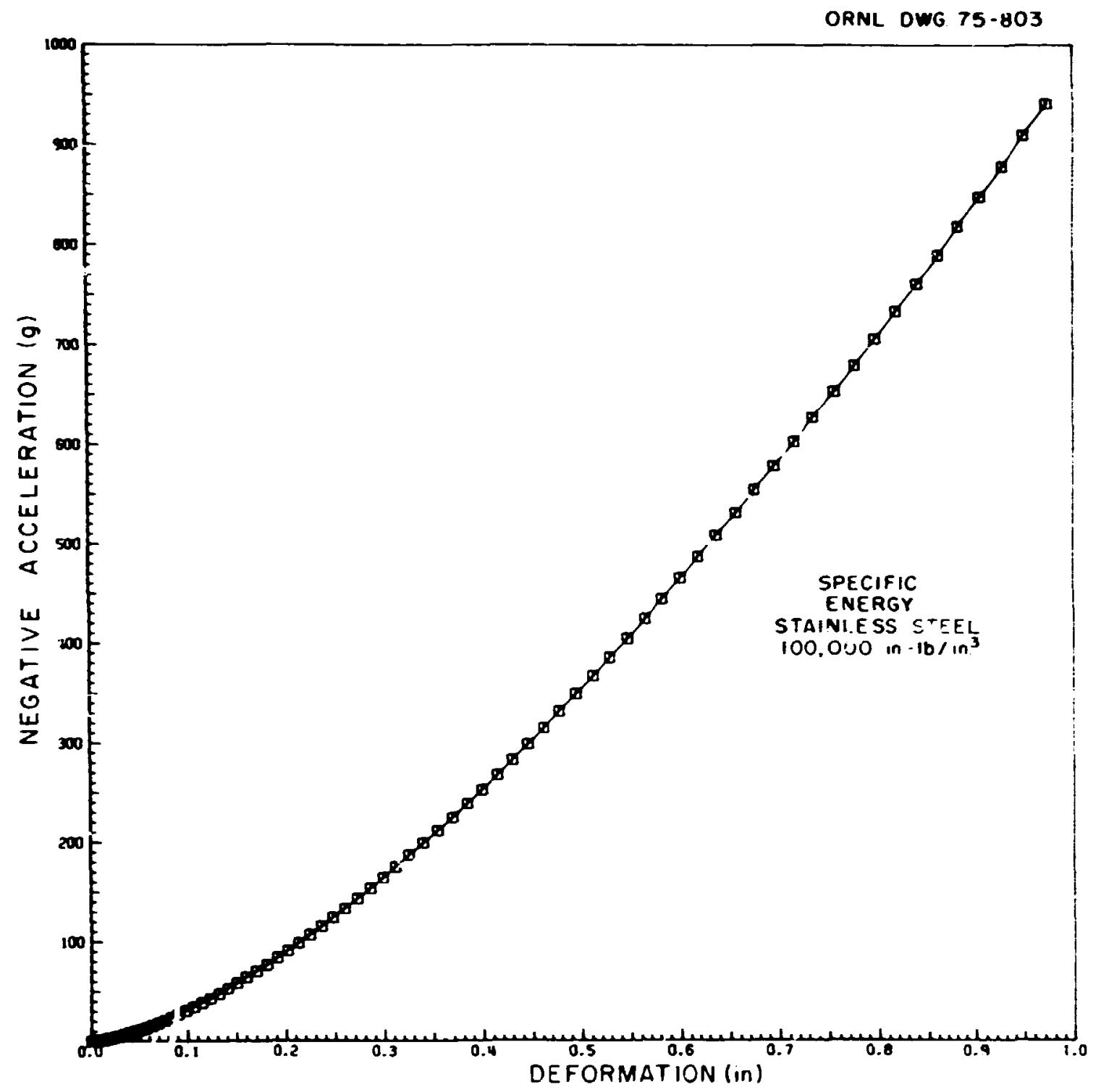

Fig. 12.2 Plot of negative acceleration vs deformation at specific energy of 100,000 in.-1b/in. ${ }^{3}$ Sor stainless steel shipping container during a $30-\mathrm{ft}$ corner drop. 


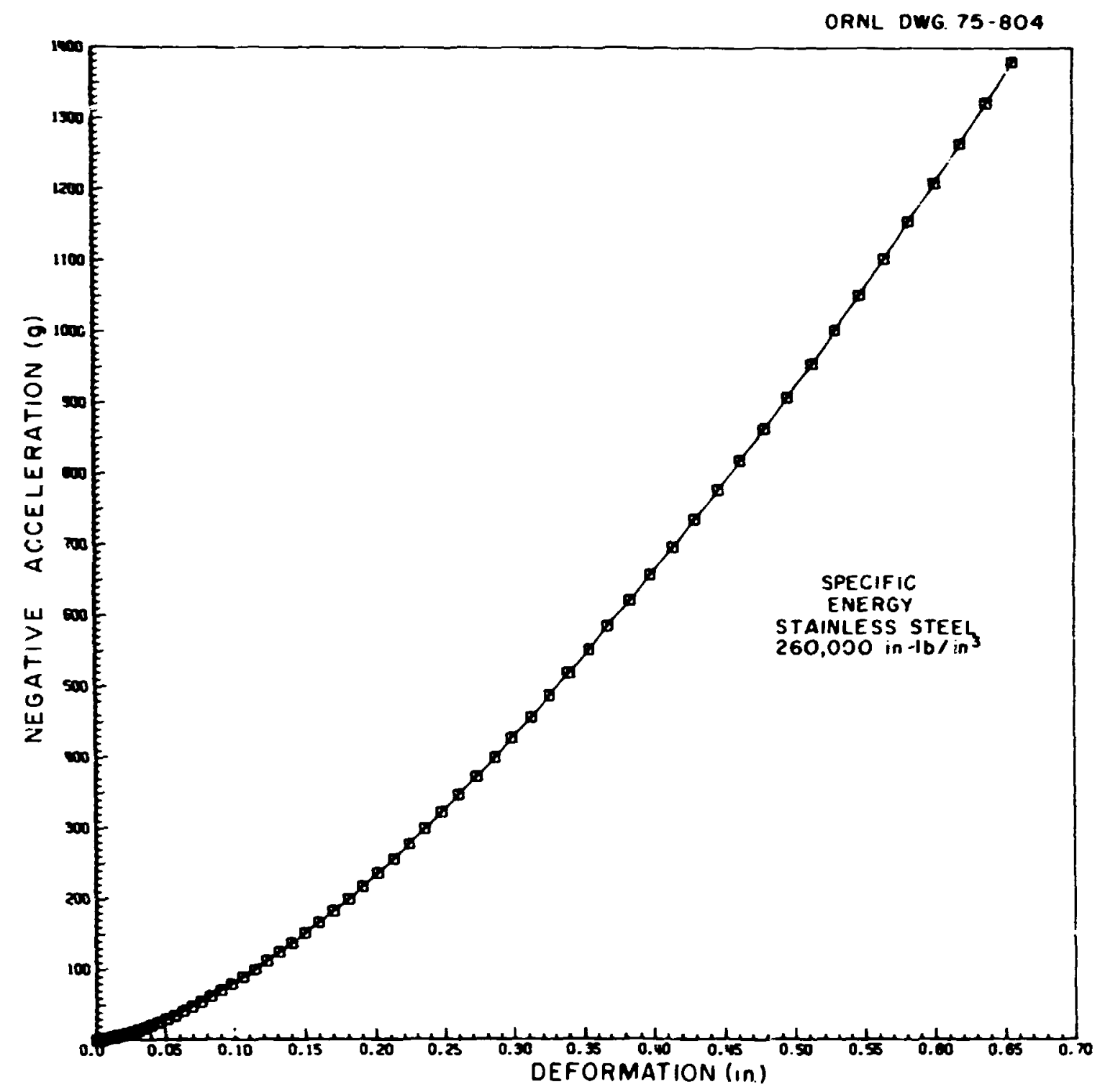

Fig. 12.3 Plot of negative acceleration vs deformation at specific enerzy of $260,090 \mathrm{in.}-1 \mathrm{~b} / \mathrm{in} .{ }^{3}$ for stainless steel shipping container during a $30-f t$ corner drop. 


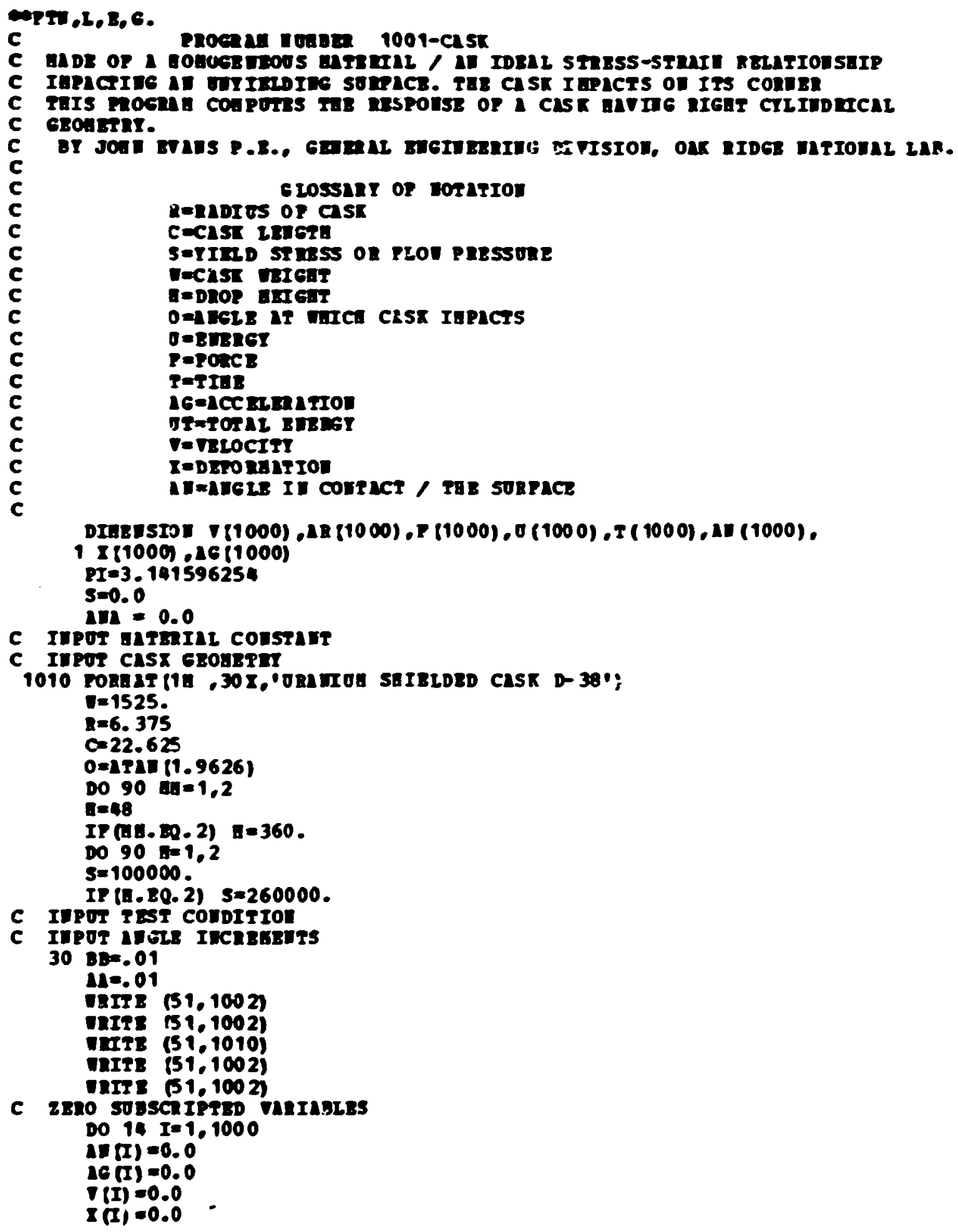




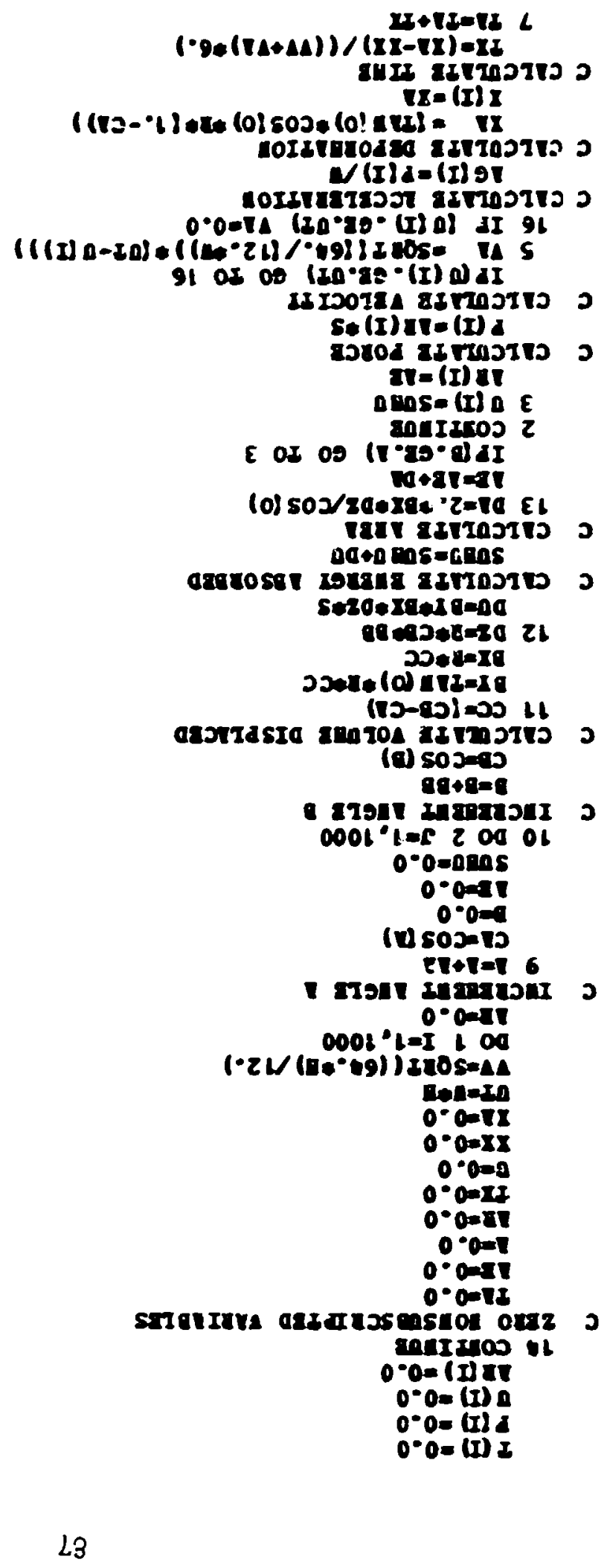




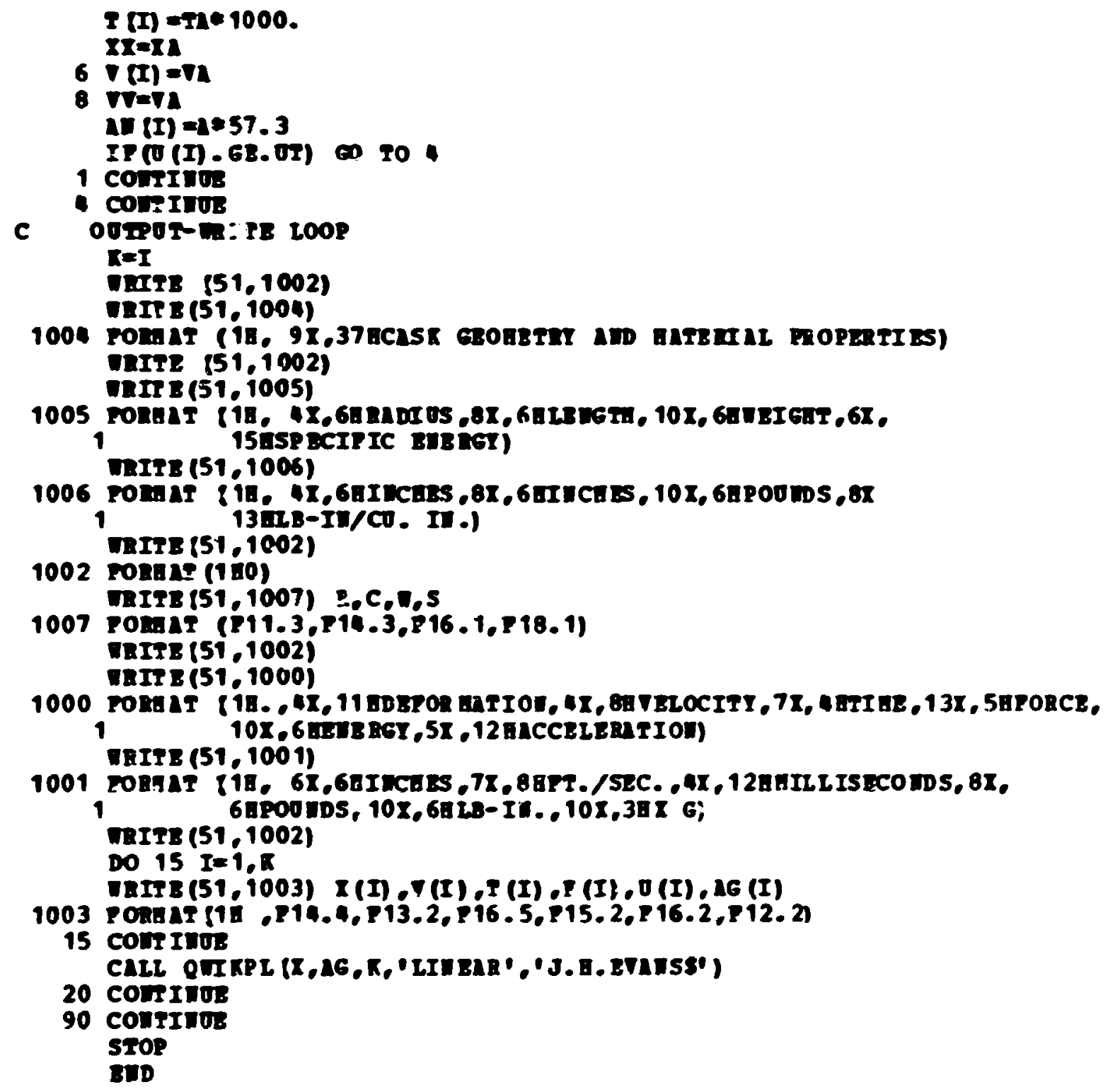


andon sxues cas b-30

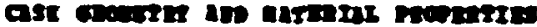

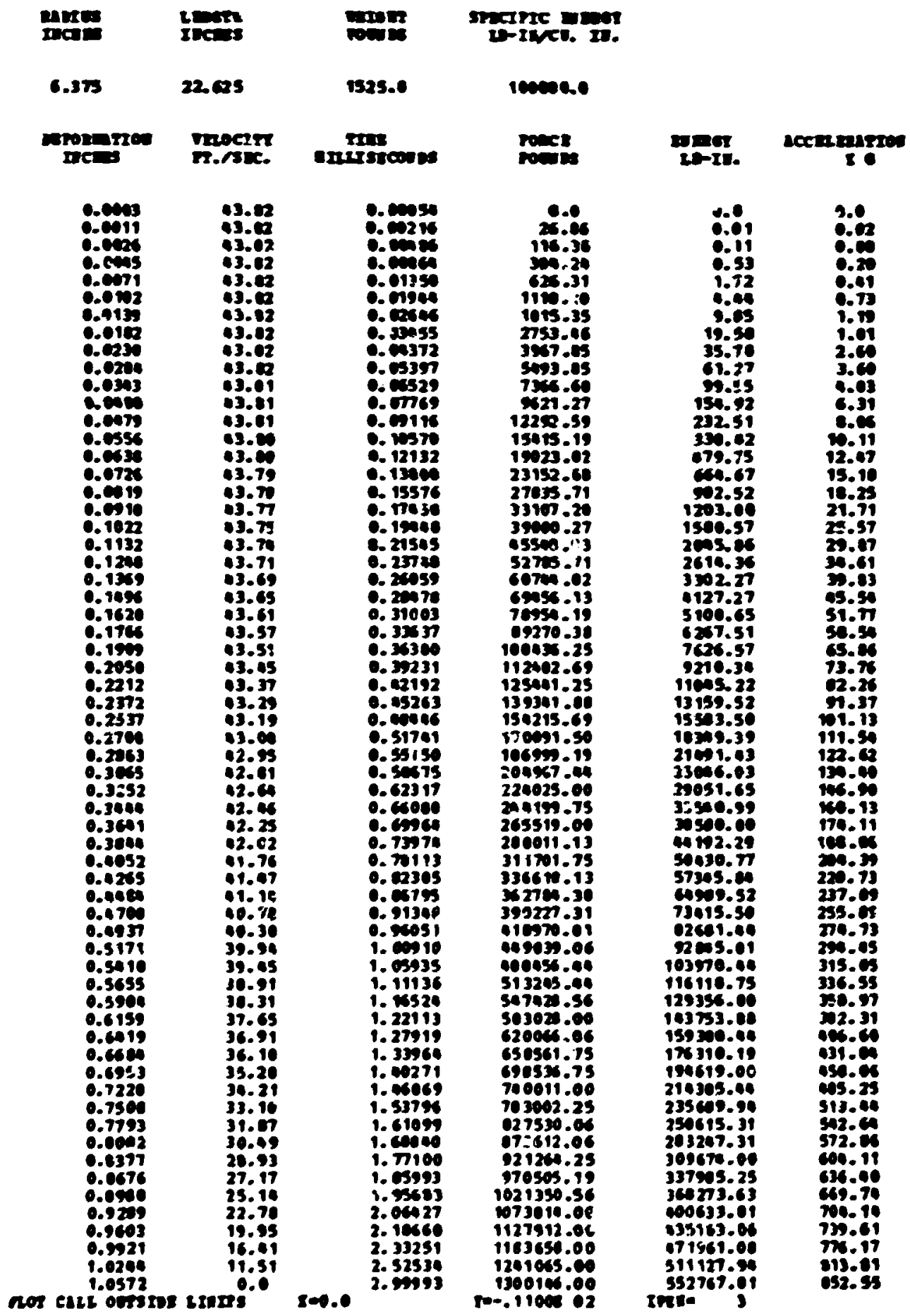




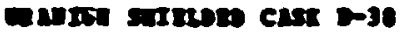

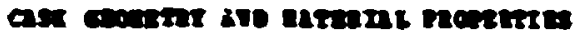

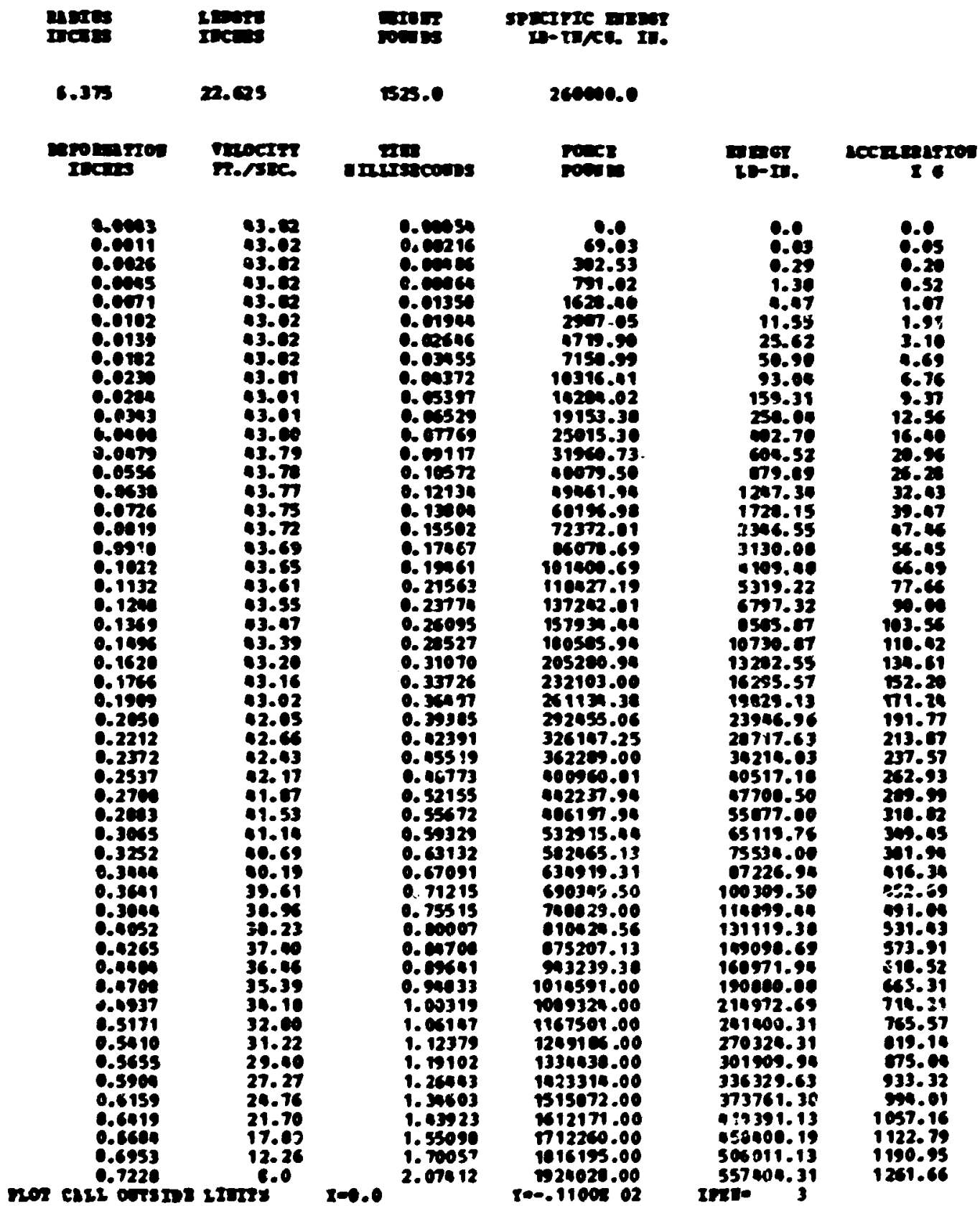

Inc0eas s200 c000 


\subsection{Appendix D: Computer Program to Calculate Side-Drop Negative Acceleration Forces}

The computer program was the same as derived in Appendix C: however, the program was changed to reflect the change in the angle of impact. The angle, $\alpha$. in Fig. 12.1 was $63^{\circ}$ for the side drop.

The computer program is given and the results of specific energies are given fr.r siainless steel of 100,006 and 260,000 in.-1b in. ${ }^{3}$. The plots of the negative accelerations is deformations are giver in Figs. 12.4 and 12.5 . 


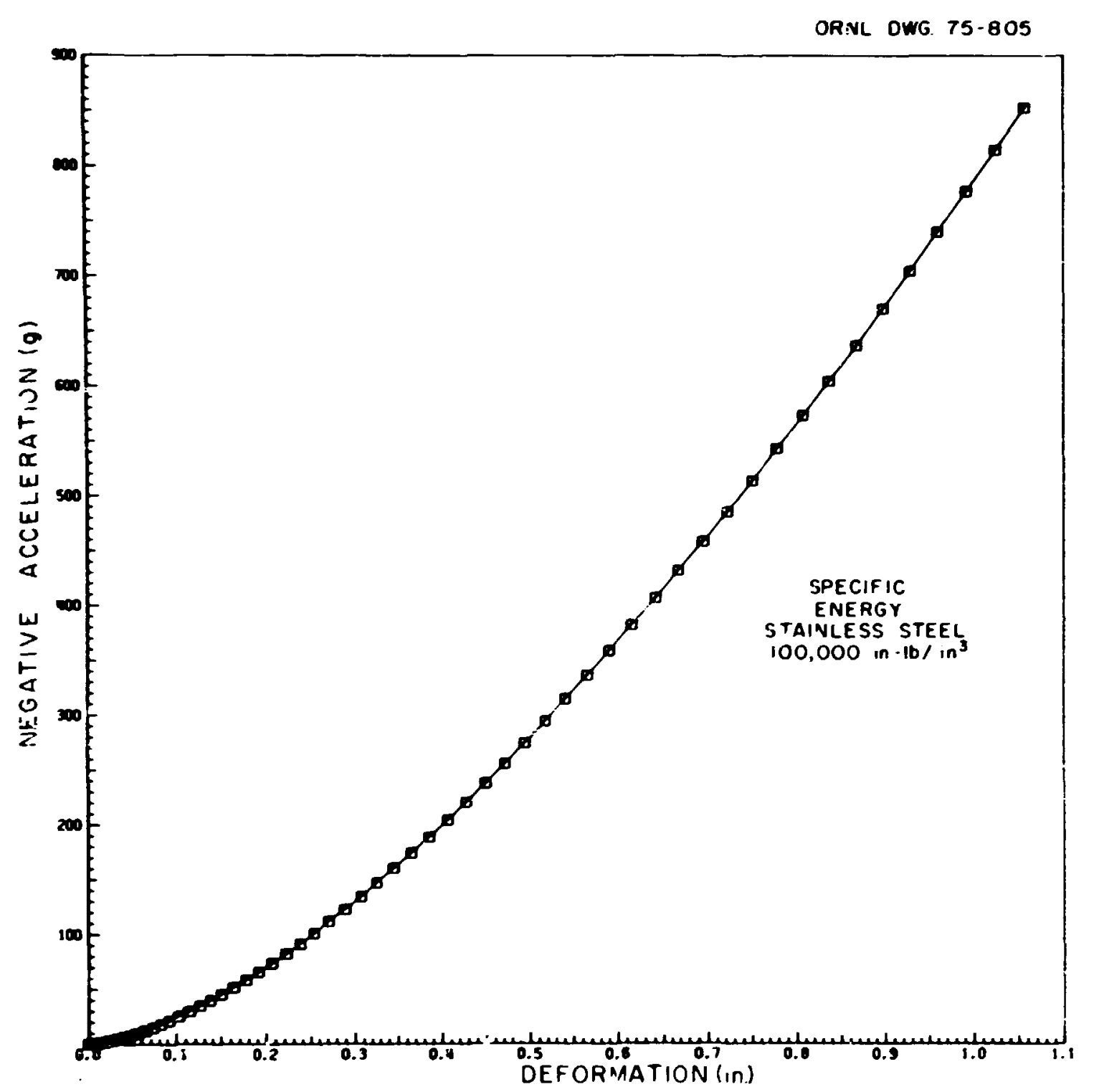

Fig. 12.4: Plot of negative acceleration vs deformation at specific energy of $100,000 \mathrm{in.}-1 \mathrm{~b} / \mathrm{in}^{3}$ for stainless steel shipping container during a $30-f t$ side drop. 


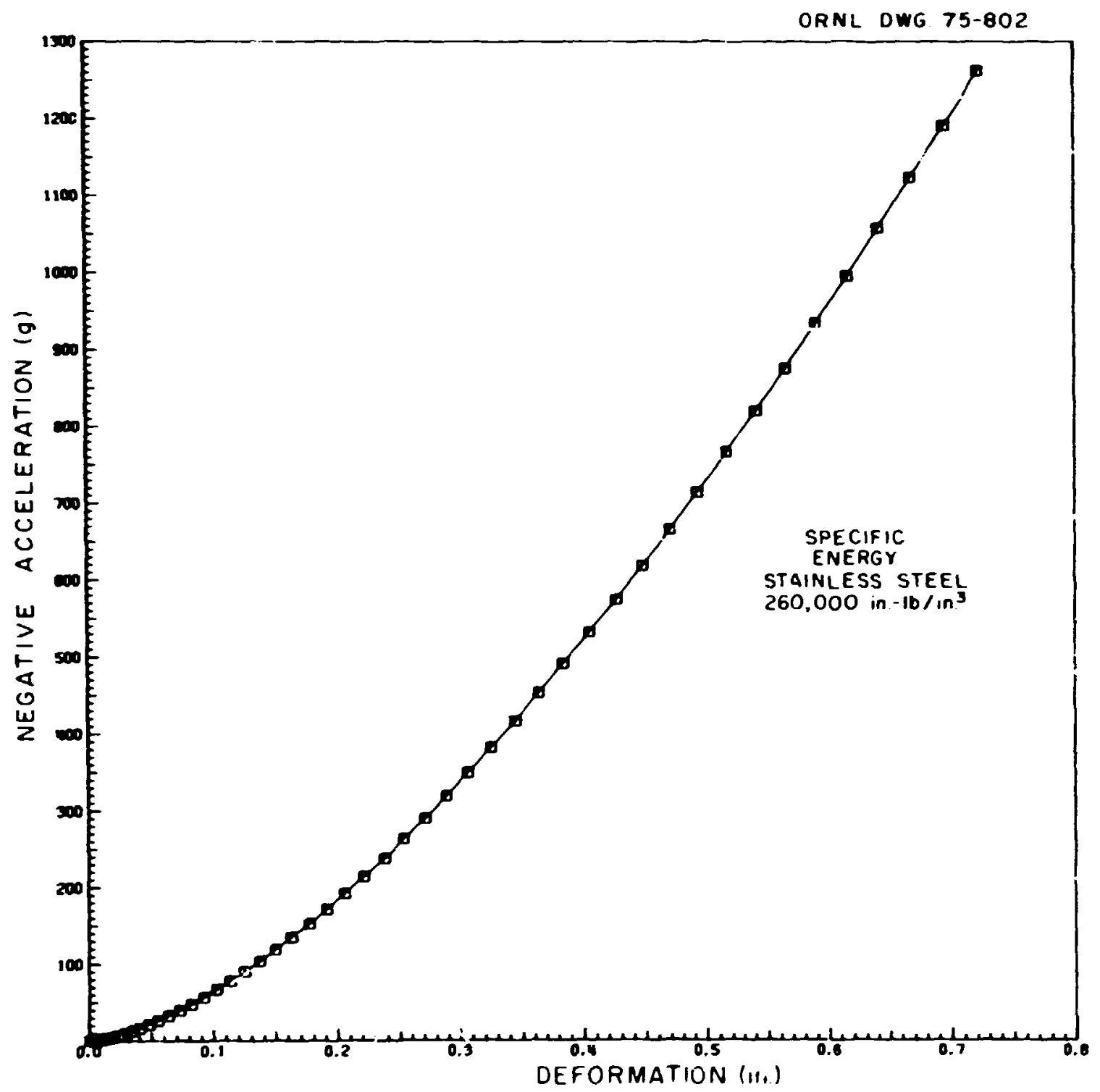

F1g. 12.5 Plot of negative acceleration vs deformatiors at specific energy of $260,000 \mathrm{in} .-1 \mathrm{~b} / \mathrm{in}^{3}$ for stainless steel shipping container during a $30-f t$ side drop. 
12.5 Appendix E

Inspection of ORNL Shipping Cask D-38

to Verify Integrity of Fabrication 


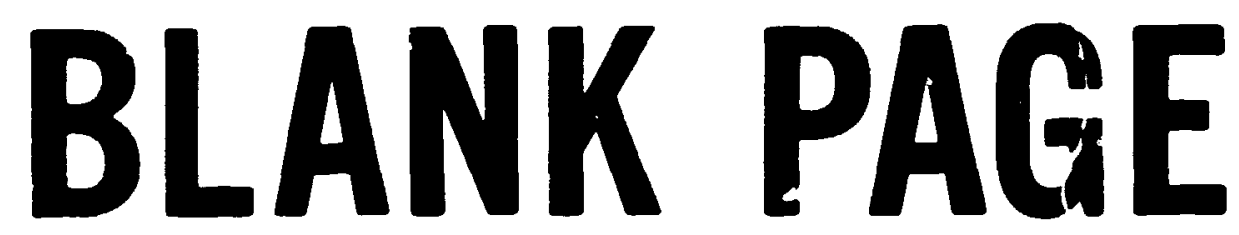 \\ BLANK PAGE




\section{INTRA.LABORATORY CORRESPONDENOE}

OAK RIJGE MSTIOMAL LABORATORY

Norember 16, 1973

No: B. B. K1Ina

SUbJer: Inopection of Shipplos Cank D-38

W.0. $\triangle-3044 C-M$ - Inopection Iequeet 10926

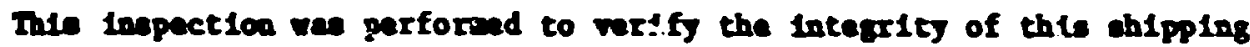
ceak.

After diecasembly, the cank was aurveyed by Obel Beelth Phyelce and found to be free of redioactive continination.

Dinual Irusection

Thie cask conforme to the charactorietice of Drawlog K-12133-CD-126-8 cev. 9.

Wo etrictural defects ene obeerved in the calk, cover ahroud or ehipping pallot.

Wall inlskneee readinge of the outer ohell (part 18 ) revesled a th1cknose of .385" - .4.88".

The cakk 10 1disocified co the shroud and tof plug by staped lettering.

\section{Liquid Penatrint Eroninat::-}

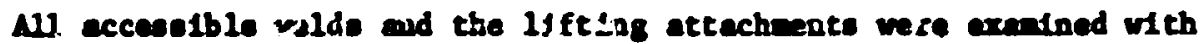

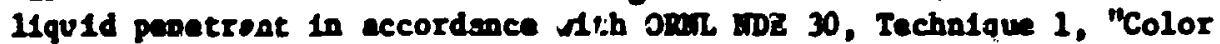
contrant Solvent-renoviole", and wre found to be satiefactory.

\section{Lenk Test}

The cank vec tellin leak teated in accordence with the Lapection Eagineering Mrnum Sacts xa 7, App. 4. Th1s test Indicated a leak rate not greater them $1 \times 10^{6}$ scc/soc. (Leak teat roport is attached).

'Ieak Test Report In Gavilty Assurance file in Room A-16, Bldg. 4500N, ORRL 


\section{Neal Identificatior:}

111 eccisel'sle partu of the caok were srandned with a thernoelectric comparator and datendised to heve bein fabricated fron 300 series otainlase greel. (Inetrunat callsation data and test reaulto are arteched.)

These Inopectione and teste Incifcate good quality welds and anterial. It 1s our oplaion that the integrity of this cask to good.

DISPECTIOA EAGINEERTIG DEPT.

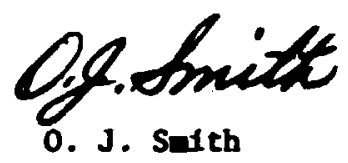

ass :bc

Attachant:

cc: J. R. HeGuffay

J. H. Roblnson

C. R. Starlin

ID-10926

Available in Quality Assurance file, Rocm A-16, Bldg. 4500N, ORNL. 
12.6 Appendix F: Operating and Inspection Procedures

Page

$\begin{array}{lr}\text { Inspection Check List } & 96\end{array}$

Operating Procedure - Incoming Shipments 98

$\begin{array}{ll}\text { Operating Procedure - Outgoing Shipments } & 100\end{array}$ 


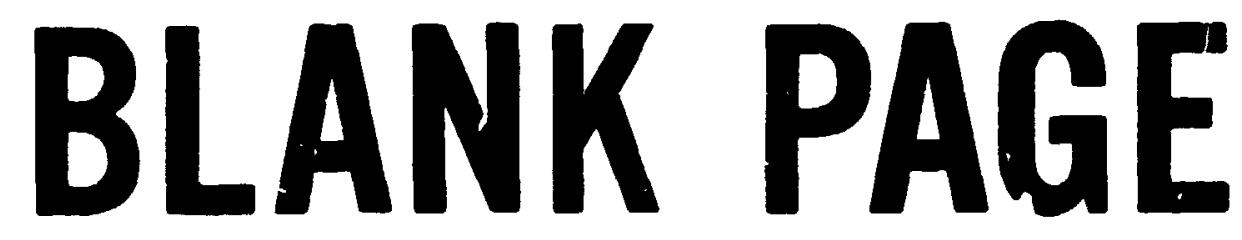 \\ BLANK PAGE}


ORI SHIPPING CASK D-38

DOT APPDOVED 5787

Ord Din. W0. R12133-CD-126-D

Inpection Check Liat Inopection Iype

Routine

Stemata:

Date 플 Bx

1.

General condition cf cask checked. Remarta:

2.

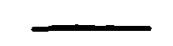

3.

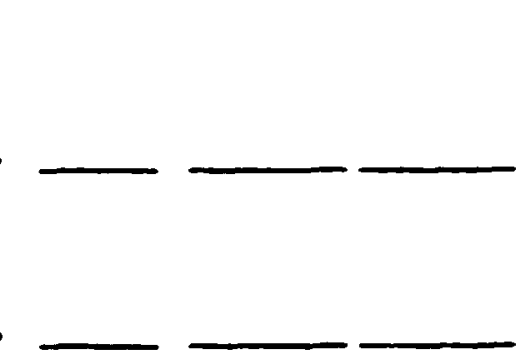

4.

5.

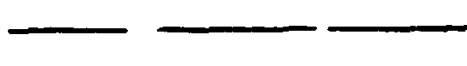

6.

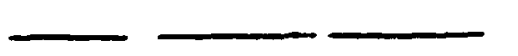

6.$$
7 .
$$$$
--
$$

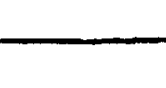

8.

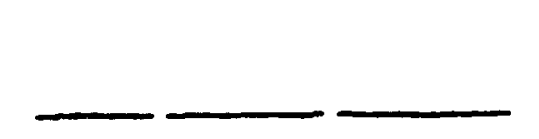

Iner covity plus flange gaket, coodltion:

poor $_{\text {good }}^{\text {p__ repleced }}$

Drain plug "0" ring gaskets, condition:

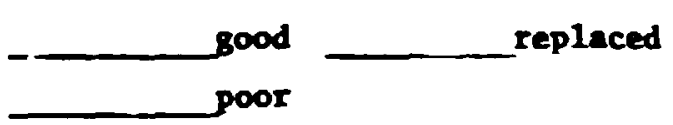

Inner cavty plug flange gasket, seniling ourface condition:

good $\ldots$ needs reworking ___ cleaned
needs cleaning

llute, condition:

___ frod

replaced

Stude, condition:

goud

reflaced

Loceting pine, condition:

good

replaced

Sifety wire holes are free:

Yes

Meeds Cleaning

clened 
Inspection Check List (Continued)
Inspection Type

Routine

Biennial

Date $\underline{\text { Tye }}$ By

9.

10.

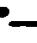

11.

1.

12. $\longrightarrow$
Visually Inspect welds (Blemial only).

Fire shleld all welds secure (dye penetrant test) (blemial only)

Pire Shield Wooden Block

Intact Should be replaced Replaced

Sk1d Lifting loops a ad velds (dye penetrant) (biennial only) 
Pave 1 of 2

Date
Fuld in $100 \frac{\Delta-16}{4500}$

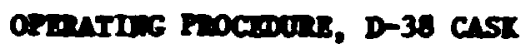

ne-on-as 5787/ar

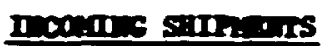

Iniedne

1. Fre shteld and stdd checked for Iaknge and denge.

2. Tomer wite impected for denpe.

3. Fre shald ronad.

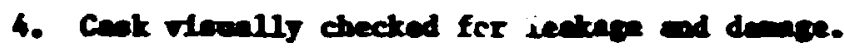

5. Atentor of cact and eldd probed and enared by Realth Phyotce for radintion andor contrination.

6. Indtation date on senk and oudd extertors:

$$
\text { coneset } 3 \mathrm{ft} \text {. }
$$

Arim

inted

Ineren

7. Fadiation date on l1d (outef de top):

$$
\text { Conenct } 3 \mathrm{ft} \text {. }
$$

Ipan

Betalcon

Enentros

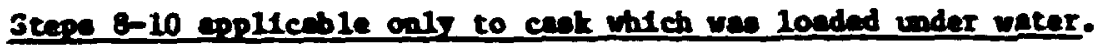

8. Dratn plus renoved. Water dratied from imer covity.

9. Dratn plus "0" rins coudieton:

o.

Repleced

10, Dratn plos repleced. 
NRC-OR-IISA-5787-BLP

Page 2 of 2

I.cosming sampers

Inteln

11. Cank renoved from okid and noved to Bot Cell area.

12. Lad bolte rewoved. Lid-lifting device sitached.

13. Outaide of calk moked or beged with plastic or paper to protect cank from contridnution.

14. Cank woved into Bot Cell (1f necesenry), I1d rateed, and contente renoved.

15. Lid replaced, cent re oved fron Hot Cell and checked for radionctive conterdnetion.

16. Radiation date on cask:

$$
\text { Contact } 3 \text { ft. }
$$

Alpha

Beta/Geran

neutron

17. Cask and I1d decontudnated to within eatobliahed shipping tolerances. Survey tag attached to cakt.

18. Indintion date on cesk and 11d:

$$
\text { centact } \quad 3 \mathrm{ft} \text {. }
$$

Alphe

Bece/com

Deutron

19. Cackete on 11d and dreln plug Inppected. Geoket coodition:

$$
\text { Lid or raplaced }
$$

20. Cakt, and protective cover reansubled, placed on the atd.

21. Fire ahield placed over cank and noved to storage area. Above Inforntion Certified Dy: 


Date
File in Boon $\frac{\$-16}{4500}$
Bulldide

DFEATIn Frockouse, D-38 cask

NRC-OS-DSA 5787/RTP

ouncons sarmans

Inteine

1. Depleted uranion metal blological ahielding edequate for quentity of radioective enterial to be ohtipped.

2. Capk woved to londing area, opened, and ganket Inopected. Gakket cosdition:

$$
\text { Led or Replaced }
$$

3. Cank body and lid covered with pleatic or paper to mainge radionctive contronination.

4. Inner contalner galket (allicone rubber) condition:

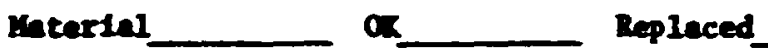

5. Radianctive enterial to be shipped placed lato Specxfication 21 contalner (or approved equivalent). Concentrated beat cources wat be placed in heat eink. Exterior of contalner the been decostandnited.

6. Imner contalner properly sealed (bolts or 11d tightened a approprinte).

7. Radintion data on Imer contalner:

$$
\text { Contact } \quad 3 \mathrm{ft} .
$$

Aphe

Deta/Genam

veotron

8. Imorer contalner loaded Into calk. Caok ganket in place. LId repleced.

9. Capik renowed from loading aren. Lid lifting device renoved.

10. If jonded under water, draln plus reoved. Water drained fron innar cavity. Dralu plus repleced.

11. L1d and ceak decontanineed to the eatabliohed tolerances for off-elte ohipeat. 
12. Rediation deta on landed cask:

$$
\text { Contact } \quad 3 \mathrm{ft} .
$$

Alpha

Bata/Gan

Bentron

13. Cover nute replaced and tightened.

14. Teper seale attached through predrilled nuts and atuds.

15. Cank placed on skid. Four 1 in. dine. nuts tightened.

16. Hoalth Physics aneared and probed cask.

\section{Contact}

\section{Alphe}

Beta/Gana

17. Fire Shield replaced and attached to studs with nuts.

18. Healta Phyolco omeared and probed fire obteld.

19. Riggers called to wre cask. 


\section{REFEREHCES}

1. J. i. Evars, Analysis of the Oa' Rijue iational Laboratory Shippine Cask D-38, ORIL-TM-2220 (October 1968).

2. Code of Federai Regulations, Title 10, Part 71.

3. DUE Yanual, Chapter 0529. Jure 14, 1973.

4. Code of Federal Regulations, Title 49, Fart 173.

5. Code of Federal Regulations, Title 49, Fart 173, Earagraph 173.393 !'”

6. R. A. Johnston, "flloying of Uranium and Stainless Steel in uraniur. Shielded Casks," p. 11 in Faducah Plant Laboratory Prcgress Repcrt, January-June 1966, KY-L-419, Fart I (Sept. 27, 1966).

7. A. N. Holden, Physical Metallurgy of Uranium, Addison-Wesley, Reading, Mass., 1958.

8. Padicah Plant Laboratory Progress Report, januarj - june ifo, KY-L-469, Part I (Dec. 2, 1768).

9. II. R. Clauser (ed.), Mater. Desin Eng. (Materials Selector Issue) 54(5), (Mid-October 1961).

10. C. A. Hampel (ed.), Rare Yetals Handbook, 2nd ed., Reirhold New York, 1961.

11. P. C. Johnson, Optimum Design of Mechanical Elements, Wiley, New York, 19001.

1.2. M. F. Spotts, Design of Machine Elements, 3rd ed., p. 74, PrenticeHall, London, $1 \not 61$.

13. Ibid, p. 45.

14. F. L. Singer, Streneth of Materials, Table XII - 2, p. 1:0;, iarper Ne: YCrk, 1951.

15. F. 3. Seely, Resistanne of Vaterials, 3r. ad., ․ 63, wiley, ifers York 1947. 
16. ASME Roiler and Pressure Vessel Cod $\epsilon$, Section VIII, Rules for Construction of Vessels, Division I, Amerizan Society of Mecianical Engineers, New York, N. Y., 1474.

17. W. D. Turner and M. Siman-Tov, HEATING-3, Ar IBM 360 reat Cor Program, ORNL-TM-3.08 (Febr:ary 1971).

18. Code of Federal Regulations, Title 49, Part 173, Paragraph 173.393 (e) $(\because)$.

19. E. Oberg and F. D. Jones, Machinery's Handbook, 16th ed., n. 1110, Industrial Press, N. Y., 1959.

20. DOE Manual 0529 Appendix, Part 1 A 15, June 14, 1973.

21. M. F. Spotts, Design of Machine Elements, 2nd ed.,p.459, Prentice-Hall, London, 1954. 